Prepared in cooperation with the National Park Service

\title{
Water Quality of Streams in and near the Delaware Water Gap National Recreation Area, Pennsylvania and New Jersey, 2002-04
}

Scientific Investigations Report 2007-5290 



\section{Water Quality of Streams in and near the Delaware Water Gap National Recreation Area, Pennsylvania and New Jersey, 2002-04}

By R. Edward Hickman and Jeffrey M. Fischer

Prepared in cooperation with the National Park Service

Scientific Investigations Report 2007-5290 


\section{U.S. Department of the Interior DIRK KEMPTHORNE, Secretary}

\section{U.S. Geological Survey \\ Mark D. Myers, Director}

\section{U.S. Geological Survey, Reston, Virginia: 2008}

For product and ordering information:

World Wide Web: http://www.usgs.gov/pubprod

Telephone: 1-888-ASK-USGS

For more information on the USGS - the Federal source for science about the Earth,

its natural and living resources, natural hazards, and the environment:

World Wide Web: http://www.usgs.gov

Telephone: 1-888-ASK-USGS

Suggested citation:

Hickman R.E., and Fischer J.M., 2008, Water quality of streams in and near the Delaware Water Gap National Recreation Area, Pennsylvania and New Jersey, 2002-04: U.S. Geological Survey Scientific Investigations Report 2007-5290, 65 p.

Any use of trade, product, or firm names is for descriptive purposes only and does not imply endorsement by the U.S. Government. Use of company names is for identification purposes only and does not imply responsibility.

Although this report is in the public domain, permission must be secured from the individual copyright owners to reproduce any copyrighted material contained within this report. 


\section{Contents}

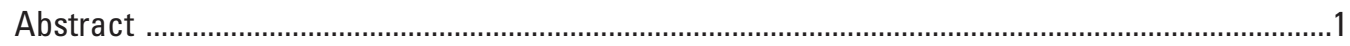

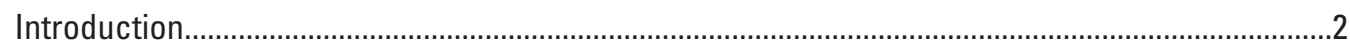

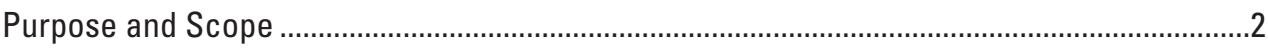

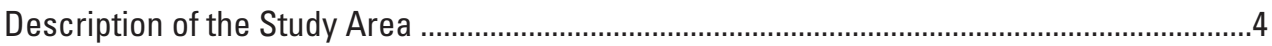

Previous Investigations...................................................................................................

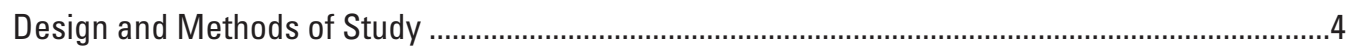

Collection of Water-Quality and Land-Use Data....................................................................

Field and Laboratory Methods...........................................................................................

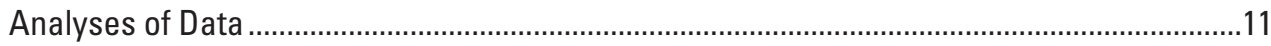

Modification of Values Reported by Laboratory ...............................................................11

Calculation of Medians with Nondetect Values ...............................................................11

Creation of Boxplots with Nondetect Values ………………............................................11

Summary of Water-Quality Values in Blanks and Replicates..........................................11

Relations Between Water-Quality and Basin Characteristics ........................................12

Equations Relating Water-Quality Characteristics, Streamflow, and Season.................12

Variation of Water Quality with Streamflow...................................................................12

Variation of Water Quality with Season .........................................................................13

Detection of Future Changes in Water Quality ...........................................................13

Water Quality of Streams in and near the Delaware Water Gap National Recreation Area,

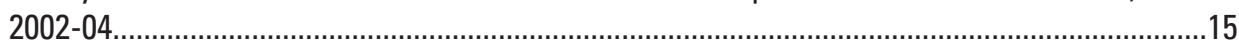

Summary of Water-Quality Characteristics at Each Station ...................................................15

Results of Analyses of Blanks and Replic ates..................................................................... 15

Variation of Water Quality with Basin Characteristics.........................................................18

Linear Equations Relating Water Quality, Streamflow, and Season ....................................23

Variation of Water Quality with Streamflow and Season ......................................................23

Detection of Future Changes in Water Quality ........................................................................31

Summary and Conclusions......................................................................................................

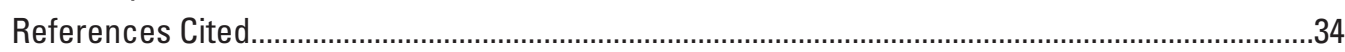

Appendixes-

1. Methods used to determine flow at stations on streams in and near the Delaware Water Gap National Recreation Area, Pa. and N.J., at times of

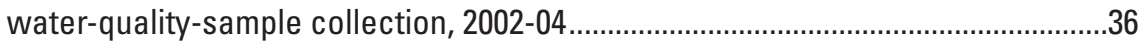

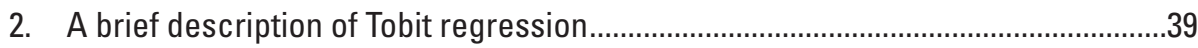

3. Summary statistics for water-quality characteristics in samples from waterquality monitoring stations on streams in and near the Delaware Water Gap National Recreation Area, Pa. and N.J., 2002-04

4. Equations relating water quality, streamflow, and season at stations on streams in and near the Delaware Water Gap National Recreation Area, Pa. and N.J., 2002-04. 


\section{Figures}

1-2. Maps showing-

1. The Delaware Water Gap National Recreation Area and vicinity, Pa. and N.J.

2. Stream water-quality monitoring stations and associated drainage basins in and near the Delaware Water Gap National Recreation Area, Pa. and

N.J., 2002-04.

3-14. Graphs showing -

3. Land use in drainage basins associated with water-quality monitoring stations on streams in and near the Delaware Water Gap National Recreation Area, Pa. and N.J., 2002-04...

4. Distribution of values of $(A) \mathrm{pH}$, acid-neutralizing capacity, specific conductance, dissolved calcium, (B) attenuation turbidity, total phosphorus, dissolved oxygen, total nitrogen, dissolved nitrate plus nitrite, and dissolved chloride at each waterquality monitoring station on streams in and near the Delaware Water Gap National Recreation Area, Pa. and N.J., 2002-04

5. Median concentrations of $(A)$ total phosphorus and $(B)$ total nitrogen at waterquality monitoring stations as a function of agricultural land use and the presence of permitted wastewater facilities in associated drainage basins, for streams in and near the Delaware Water Gap National Recreation Area, Pa. and N.J., 2002-04......

6. Median concentrations of total phosphorus and total nitrogen at water-quality stations as a function of wetland area and the presence of permitted wastewater facilities in associated drainage basins, for streams in and near the Delaware Water Gap National Recreation Area, Pa. and N.J., 2002-04.

7. Median values of attenuation turbidity at water-quality monitoring stations as a function of wetland area in the associated drainage basins, for streams in and near the Delaware Water Gap National Recreation Area, Pa. and N.J., 2002-04...

8. Concentration of dissolved nitrate plus nitrite as a function of $(A)$ streamflow and $(B)$ day of the year at the water-quality monitoring station (01438754) on Adams Creek below Long Meadow Brook near Edgemere, Pa., near the border of the Delaware Water Gap National Recreation Area, Pa. and N.J., 2002-04

9. Total phosphorus as a function of $(A)$ streamflow and $(B)$ day of the year at the water-quality monitoring station (01438892) on Dingmans Creek above Dingmans Falls near Dingmans Ferry, $\mathrm{Pa}$., near the border of the Delaware Water Gap National Recreation Area, Pa. and N.J., 2002-04 .

10. Total nitrogen concentration as a function of $(A)$ streamflow and $(B)$ day of the year at the water-quality monitoring station (01439830) on Big Flat Brook at Tuttles Corner, Pa., near the border of the Delaware Water Gap National Recreation Area,

Pa. and N.J., 2002-04

11. Attenuation turbidity as a function of streamflow at the water-quality monitoring station (01438700) on the Raymondskill Creek near Milford, Pa., near the border of the Delaware Water Gap National Recreation Area, Pa. and N.J., 2002-04... 
12. Dissolved chloride as a function of $(A)$ streamflow and $(B)$ day of the year at the water-quality monitoring station (01439570) on the Sand Hill Creek at Bushkill, Pa., near the border of the Delaware Water Gap National Recreation Area, Pa. and N.J., 2002-04...

13. Values of $\mathrm{pH}$ as a function of streamflow at the water-quality monitoring station (01439680) on the Little Bush Kill at Bushkill, Pa., near the border of the Delaware Water Gap National Recreation Area, Pa. and N.J.,2002-04

14. Dissolved oxygen concentration as a function of streamflow at the water-quality monitoring station (01438700) on the Raymondskill Creek near Milford, Pa., near the border of the Delaware Water Gap National Recreation Area, Pa. and N.J., July-September, 2002-04 


\section{Tables}

1. Water-quality monitoring stations on streams in and near the Delaware Water Gap National Recreation Area, Pa. and N.J., 2002-04

2. Land-use characteristics of basins associated with water-quality monitoring stations on streams in and near the Delaware Water Gap National Recreation Area, Pa. and N.J., 2002-04

3. Number of measurements of physical characteristics, plant nutrients, major ions, and organic compounds at stations on streams in and near the Delaware Water Gap National Recreation Area, Pa. and N.J., 2002-04 .

4. Selected water-quality characteristics measured at stations on streams in and near the Delaware Water Gap National Recreation Area, Pa. and N.J., 2002-04.

5. Summary of results of analyses of blanks and replicates from water-quality monitoring stations on streams in and near the Delaware Water Gap National Recreation Area, Pa. and N.J., 2002-04 .

6. Results of correlation tests between median values of water-quality characteristics at each water-quality monitoring station and the land use in the drainage basin, for streams in and near the Delaware Water Gap National Recreation Area, Pa. and N.J., 2002-04.

7. Identification of increases and decreases in values of selected water-quality characteristics with increasing streamflow, at stations on streams in and near the Delaware Water Gap National Recreation Area, Pa. and N.J., 2002-04.

8. Identification of water-quality characteristics with values that varied with season, at stations on streams in and near the Delaware Water Gap National Recreation Area, Pa. and N.J., 2002-04 .

9. Minimum detectable differences between current (2002-04) and future water-quality values for stations on streams in and near the Delaware Water Gap National Recreation Area, Pa. and N.J., 2002-04, assuming 10 future measurements. 


\section{Conversion Factors and Water-Quality Units}

Inch/Pound to SI

\begin{tabular}{lcc}
\hline Multiply & By & To obtain \\
\hline square mile & Area & \\
\hline & 2.590 & square kilometer \\
\hline cubic feet per second $\left(\mathrm{ft}^{3} / \mathrm{sec}\right)$ & Flow rate & \\
\hline
\end{tabular}

Temperature is given in degrees Celsius $\left({ }^{\circ} \mathrm{C}\right)$, which can be converted to degrees

Fahrenheit $\left({ }^{\circ} \mathrm{F}\right)$ by the following equation:

$$
{ }^{\circ} \mathrm{F}=1.8\left({ }^{\circ} \mathrm{C}\right)+32
$$

\section{Water-Quality Units}

Concentrations of some constituents in water samples are given in milligrams per liter (mg/L), which is equivalent to "parts per million". 



\title{
Water Quality of Streams in and near the Delaware Water Gap National Recreation Area, Pennsylvania and New Jersey, 2002-04
}

\author{
By R. Edward Hickman and Jeffrey M. Fischer
}

\section{Abstract}

Water samples were collected during 2002-04 at monitoring stations on 14 streams either within or entering the Delaware Water Gap National Recreation Area. The samples were collected from April through December of each year, mostly under low (base-flow) conditions, and were analyzed for major ions and nutrients (nitrogen and phosphorus). Results of the analyses, in concert with land-use information in the drainage basins associated with the samples, were used to define water-quality characteristics; to identify relations among water quality, streamflow, and season; and to establish a baseline and develop a method that could be used to detect future changes in water quality.

For a given water-quality characteristic, median values commonly varied among the 14 water-quality monitoring stations. For example, the median concentration of total phosphorus at the station on Sand Hill Creek (0.033 milligrams per liter as $\mathrm{P}$ ) was four times the corresponding median concentration at the station on Vancampens Brook (0.008 milligrams per liter as $\mathrm{P})$.

Results of correlations between median values of waterquality characteristics and land-use characteristics of the drainage basins indicate that agricultural practices and the presence of wetlands could be important factors affecting the concentrations of total nitrogen and total phosphorus in these streams. Results of analyses of samples from the nine stations without permitted wastewater facilities in their basins indicate that medians of both total phosphorus and total nitrogen increased with an increase in the area of agricultural land in the drainage basins; the levels of significance are 0.01 for total phosphorus and 0.01 for total nitrogen. When only the seven stations without permitted wastewater facilities and with less than 5 percent of the basin in agricultural land are considered, median concentrations of total phosphorus and total nitrogen increased with an increase in the area of wetlands in the basins; the levels of significance are 0.003 for total phosphorus and 0.03 for total nitrogen.

Linear equations between values of each water-quality characteristic at a station, streamflow, and season were developed by use of Tobit regression. The variations of water quality with streamflow and with season were identified from these equations.

Concentrations of total phosphorus, total nitrogen, and attenuation turbidity increased with increasing streamflow at more stations than concentrations decreased with increasing streamflow. Concentrations of dissolved orthophosphate phosphorus, dissolved nitrate plus nitrite, dissolved ammonia, and major ions decreased with increasing streamflow at more water-quality stations than concentrations increased with increasing streamflow.

Most water-quality characteristics varied with season at most stations due to reasons other than the seasonal variation in streamflow. Concentrations of total phosphorus and total nitrogen during the summer (July-September) often exceeded concentrations during the spring (April-June) and fall (October-December). As one example, concentrations of total nitrogen at the monitoring station on Big Flat Brook are between 0.1 and 0.2 milligrams per liter as $\mathrm{N}$ in the spring and fall, but increase to between 0.2 and 0.3 milligrams per liter as $\mathrm{N}$ during the summer.

A method based on the linear equations relating water quality to streamflow and season was developed to detect differences in water quality between current (2002-04) and future conditions. Changes in water quality would be identified by detecting differences between the intercept of the equation with current water quality and the intercept of the corresponding equation with future water quality. The intercept represents an estimate of the water quality at a station with a streamflow of 1 cubic foot per second during a season in which the seasonal variation of water quality is minimal.

The method to detect future changes in water quality allows for an estimate of the minimum amount of change from current water quality (2002-04) that can be detected. For example, if 10 measurements are made in the future, the minimum detectable changes in total phosphorus or total nitrogen at any of the stations are 4-12 percent of the intercepts in equations with current water quality. 


\section{Introduction}

The Delaware Water Gap National Recreation Area (DWGNRA) straddles the boundary between the States of Pennsylvania and New Jersey (fig. 1). The natural beauty of this region, combined with its proximity to two major metropolitan areas (New York and Philadelphia), draws more than 5 million visitors to the DWGNRA each year. Most of these visitors arrive in the summer for water-based recreation such as canoeing, kayaking, swimming, and fishing.

The counties adjacent to the Delaware Water Gap National Recreational Area have been undergoing considerable population growth. For example, during 2000-05, the estimated increases in population of Sussex County, New Jersey, and Pike County, Pennsylvania, were 6 percent and 22 percent, respectively (U.S. Census Bureau, 2006a). The population growth in Pike County is expected to continue; a 23-percent increase during 2005-10 is forecast by the Pike County Office of Community Planning (Michael Mrozinski, Pike County Office of Community Planning, written communication, 2006).

Future increases in population in the adjacent counties are likely to cause undesirable changes in water quality in the streams flowing into and through the DWGNRA. Concentrations of nitrogen, phosphorus, and dissolved chloride in the streams may increase with increasing urban development due to increased discharge from wastewater treatment plants and (or) septic systems. These changes in water quality may, in turn, produce undesirable changes in the aquatic biota in these streams; algae may increase and populations of pollutionintolerant fish may be reduced.

The Delaware River Basin Commission (DRBC), which oversees the management of the water resources within the Delaware River Basin, has recognized the need to protect the exceptional water quality and ecology of the tributaries of the Delaware River within DWGNRA. In 1992, the DRBC designated these waters "Outstanding Basin Waters" and enacted the "Special Protection Water Regulations." These regulations prohibit human development from causing any measurable change in water quality in the streams draining to the Delaware River within the DWGNRA.

To use these anti-degradation regulations to protect the water quality of the DWGNRA tributaries, three types of information are needed. First, sufficient data are needed to describe current water quality. Although water-quality data have been collected by Pike and Monroe counties in Pennsylvania, the States of Pennsylvania and New Jersey, the DRBC, and the NPS, these data are not considered sufficient to define current water quality. Many streams were not sampled or sampled only quarterly. Methods differed from agency to agency. Some laboratory methods had high reporting levels resulting in many nondetect values.

Second, there needs to be a method to indicate whether the future water quality will be different from the current water quality. Water quality often varies with streamflow and season. For instance, concentrations of phosphorus and nitrogen in streams typically are elevated during high spring and summer streamflow following fertilizer applications; alternately, concentrations in streams downstream from metropolitan areas may be highest during periods of low flow, when contributions from point sources are greater relative to streamflow, and dilution is less (U.S. Geological Survey, 1999). Therefore, a method is more likely to detect changes between current and future water quality if the variations of water quality with stream and season are accounted for.

Third, there needs to be a plan to monitor water quality in the future to allow detection of changes between current and future water quality. This plan should be designed on the basis of the method used to detect changes between current and future water quality.

To address these issues, the DWGNRA received funding from the NPS-USGS Water Quality Assessment and Monitoring Partnership for a project to provide baseline water-quality data and an understanding of water-quality in streams entering the Delaware Water Gap National Recreation Area. Objectives of this investigation were

- Collect samples of water in 14 streams within or entering the Delaware Water Gap National Recreation Area during selected seasons in 2002-03 and analyze them for concentrations of plant nutrients and major ions; the period of data collection was changed to 2002-04 because of drought conditions in 2002.

- Provide an overall assessment of the current and potential effects of development on long-term and episodic water quality in streams.

- Develop a cost effective strategy for future monitoring.

\section{Purpose and Scope}

The purpose of this report is twofold. First, selected results of the analyses of water samples collected at monitoring stations on 14 streams in and near the Delaware Water Gap National Recreation Area during the spring, summer, and fall of 2002-04 are presented. The water-quality properties and constituents discussed in this report are dissolved oxygen, specific conductance, $\mathrm{pH}$, attenuation turbidity, phosphorus and nitrogen species, acid-neutralizing capacity, dissolved calcium, and dissolved chloride.

Some basin characteristics that appear to affect water quality, such as land use, geology, and the presence of permitted wastewater facilities, are identified. Also identified was whether values of a water-quality characteristic at a station (a) increased or decreased with increasing streamflow, and (or) (b) changed with the season. Summary statistics and boxplots are provided for each water-quality characteristic at each monitoring station.

Second, a method to detect differences between current water quality and water quality measured in the future 


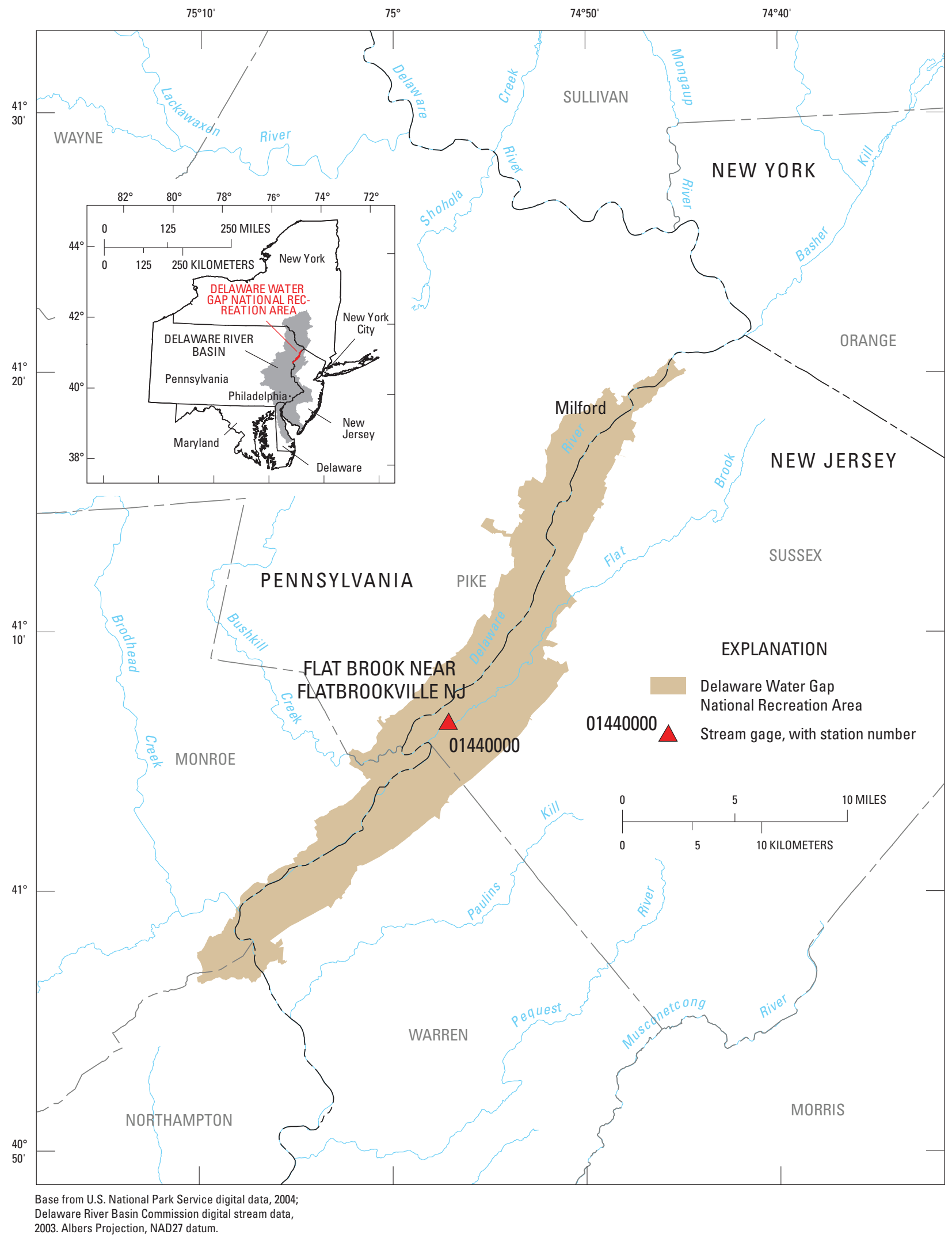

Figure 1. The Delaware Water Gap National Recreation Area and vicinity, Pa. and N.J. 
is described. Estimates of the minimum amount of change in each water-quality characteristic that can be detected are presented.

\section{Description of the Study Area}

The Delaware Water Gap National Recreation Area is a 69,300-acre park maintained by the National Park Service (NPS) along a 40-mile reach of the Delaware River (fig. 1). The park is mostly undeveloped; 81 percent is forested (fig. 2).

Numerous tributaries of the Delaware River pass through the park; some of these tributaries are shown in figure 2. Most of the drainage basins of these tributaries are outside of the park, and only the most downstream parts of the basins are within the park.

Most of the tributaries to the Delaware River within the DWGNRA have very high quality water, according to the National Park Service (National Park Service, 2006). Some of these tributaries support self-sustaining populations of eastern brook trout (Salvelinus fontinalis), a fish that survives only in the coldest and cleanest water (Eastern Brook Trout Joint Venture, 2006).

\section{Previous Investigations}

Available information suggests that concentrations of phosphorus and nitrogen are likely to increase due to an increase in discharges from wastewater treatment plants and (or) septic systems, as well as from other sources such as increased soil erosion and fertilizer use. The USGS (1999) summarized concentrations of phosphorus and nitrogen in selected streams throughout the Nation; in general, concentrations were greater in streams draining predominantly urban basins than in streams draining undeveloped basins. Fischer and others (2004) examined base-flow concentrations of total nitrogen and total phosphorus measured during May and June 1999-2001 in streams with drainage basins composed of 10 percent or less agricultural land use and located in the Delaware River Basin; they concluded that concentrations in streams with drainage basins composed of more than 10 percent urban land were greater than corresponding concentrations in streams with basins composed of less urban land They also noted that the percentage of all samples (base-flow and stormflow) in which phosphorus concentration exceeded 0.1 milligrams per liter as phosphorus increased with the percentage of basin composed of urban land. Heisig (2000) reported the results of base-flow samples collected on streams draining mostly unsewered basins in the Croton Watershed in New York State during 1996-97; Heisig concluded that concentrations of nitrate in streams under base-flow conditions increased with the density of unsewered housing in the basin.

Concentrations of dissolved chloride also may increase with increasing urban development due to increased discharge from wastewater treatment plants and (or) septic systemschloride is commonly present in domestic wastewater-as well as that washing off road surfaces. Fischer and others (2004) reported that concentrations of dissolved chloride measured in streams under base-flow conditions in the Delaware River Basin during May and June 1999-2001 increased with the road density in the basin. Heisig (2000) reported that chloride concentrations measured under base-flow conditions during 1996-97 in the Croton Watershed increased with the amount of salt applied to roads in the basins.

The effects of increasing urbanization, including increases in concentrations of plant nutrients and dissolved chloride in the streams, may cause undesirable changes in aquatic biota in these streams. From stream samples collected in the Delaware River Basin during 1998-2001, Fischer and others (2004) reported that EPT richness (the number of mayflies, stoneflies, and caddisflies) and habitat quality of the streams declined with increasing road density. The decline in EPT richness indicates that the relative abundance of pollution-sensitive benthic invertebrates decreased with increasing road density.

\section{Design and Methods of Study}

Current stream water quality conditions in the Delaware Water Gap National Recreation Area were determined on the basis of the collection and analysis of samples from 14 monitoring stations on tributaries to the Delaware River that pass through the Delaware Water Gap National Recreation Area. The data resulting from field measurements and from laboratory chemical analysis of water samples were summarized; analyzed by graphical and statistical methods to identify relations between water quality, streamflow, season, and (or) basin characteristics; and used to determine the minimum amounts of future change in properties and constituent concentrations at a station which could be detected by a described method.

\section{Collection of Water-Quality and Land-Use Data}

The 14 stations where samples were collected are described in table 1 and the locations are shown in figure 2. Stations were selected (1) to be near to or within the park, (2) to represent a range of development conditions, (3) to be suitable for water-quality sampling and streamflow measurement, and (4) to include as many streams as feasible.

Of these stations, 13 are located on the tributaries near where they enter the park (fig. 2, table 1). The basins associated with these stations range in size from 3.7 to $117 \mathrm{mi}^{2}$ and lie either entirely or almost entirely outside of the park. The 7.4- $\mathrm{mi}^{2}$ drainage basin of the station on Vancampens Brook (station 01440100) lies entirely within the park.

The land-use data used to characterize these basins were obtained from the interpretation of satellite imagery collected during the early to mid 1990s (1992 National Land Cover Data), modified to represent the amount of urban land in 2000. A description of the 1992 National Land Cover Data 


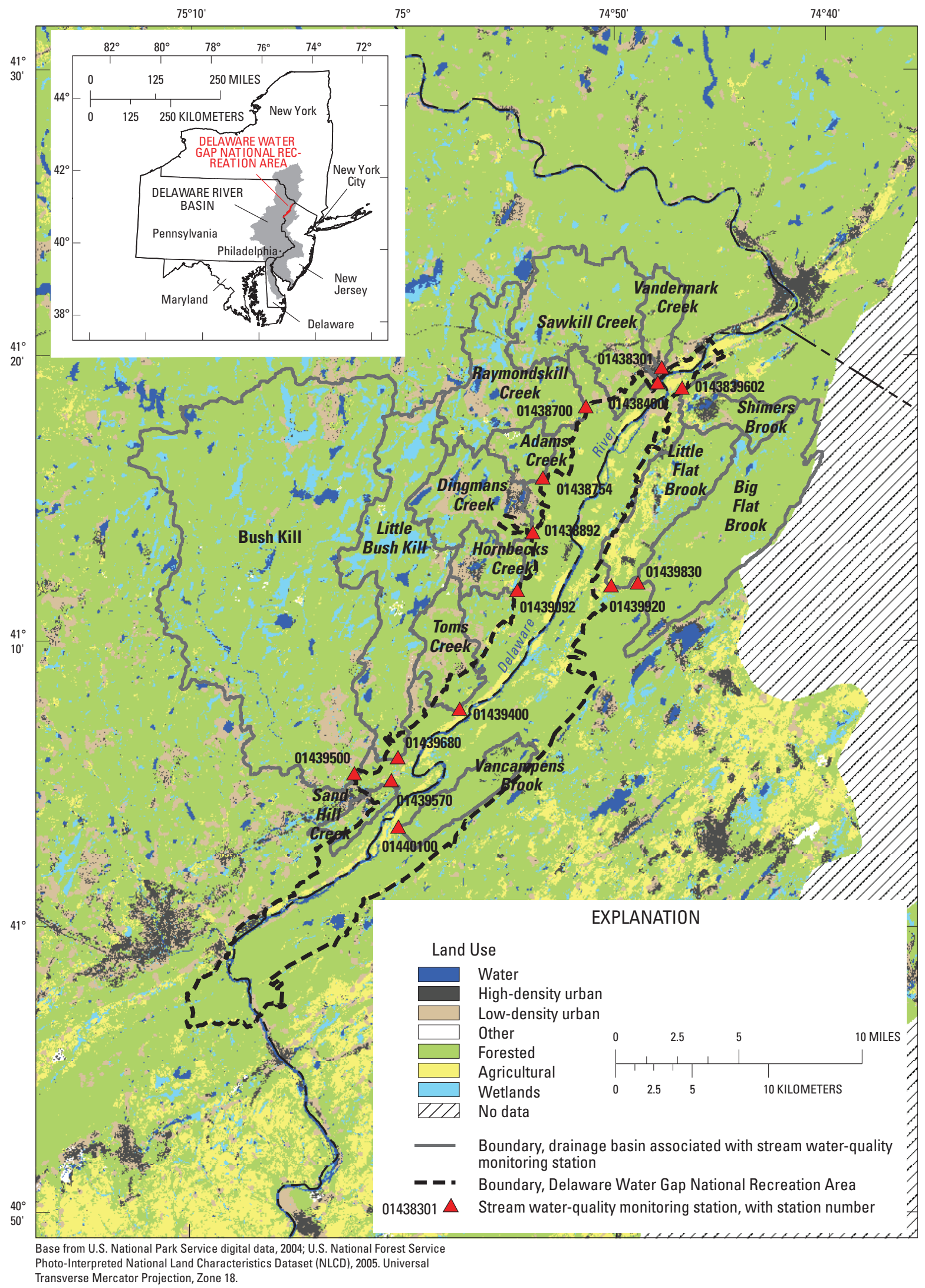

Figure 2. Stream water-quality monitoring stations and associated drainage basins in and near the Delaware Water Gap National Recreation Area, Pa. and N.J., 2002-04. 
(NLCD92) can be found in a report by the U.S. Geological Survey (2006). Data in the NLCD92 were modified by Rachel Riemann (U.S. Forest Service, written commun., 2005) to effect two changes. On the basis of local road density levels, the classification of some pixels was changed from "undeveloped" to "urban." This had two effects - first, correcting for development not recognized because of leaf cover and procedures originally used to classify the imagery, and second, changing the extent of urban land depicted in the NLCD92 to that which existed in 2000. This was accomplished by merging NLCD92 information for the basins with local road density calculated from the 2000 TIGER Line dataset (U.S. Census Bureau, 2006b). Those pixels classified as "forested", "agriculture", or "transition" in the NLCD92 were reclassified as "low-intensity urban use" if the road density of the pixel was above a certain threshold. These techniques are described in Lister and others (2005).

The drainage basins associated with the stations are predominantly forested; forest land use makes up 63 percent or more of the area of each basin (table 2; fig. 3). High-density urban land accounts for a maximum of 8 percent of each basin; low-density urban land, a maximum of 22 percent; and agricultural land, a maximum of 18 percent.

As shown in table 2, some type of permitted wastewater facility is discharging to the basin of 5 of the 14 streams. This information was provided by the New Jersey Department of Environmental Protection (Thomas Cosmas, written commun., 2007) and obtained from the Pennsylvania Department of Environmental Protection website, accessed April 3, 2007, at http://www.emappa.dep.state.pa.us/emappa/viewer.htm. The permitted discharges include discharges from septic systems.

\section{Field and Laboratory Methods}

Physical characteristics and concentrations of plant nutrients and major ions were either measured in the field by NPS and USGS personnel or determined from laboratory analysis of samples they collected (table 3 ). Values of all water-quality characteristics were stored in the USGS National Water Information System (NWIS) computer system (described in Mathey, 1998) and can be retrieved from the NWIS website http://waterdata.usgs.gov/usa/nwis/qw; these data have also been published in Deluca and others $(2005,2006)$. An additional sample collected at each station was analyzed for manmade organic compounds; results are presented in Deluca and others (2005) and are available from NWIS.

Field measurements were made and samples were collected for analyses during May-November of 2002 and April-December of 2003 and 2004 (table 3); there were no measurements or samples during January-March. Samples for plant nutrients were collected 12 to 15 times per year at each station; samples for major ions were collected at least 5 times per year (about every 6 weeks). Samples were collected over a range of flow conditions, but most were collected under "base-flow" conditions (times other than during or immediately following storms). During spring (March-May) and fall (October-December), samples were collected approximately

Table 1. Water-quality monitoring stations on streams in and near the Delaware Water Gap National Recreation Area, Pa. and N.J., 2002-04.

[Short name, shortened version of station name; latitude and longitude are in degrees, minutes, seconds; drainage area is in square miles; Cr, creek; Br, brook]

\begin{tabular}{lllccc}
\hline \multicolumn{1}{c}{ Short name } & $\begin{array}{c}\text { Station } \\
\text { number }\end{array}$ & \multicolumn{1}{c}{ Station name } & Latitude & $\begin{array}{c}\text { Longitude } \\
\text { Drainage } \\
\text { area }\end{array}$ \\
\hline Adams Creek & 01438754 & Adams Creek below Long Meadow Brook near Edgemere, Pa. & 411540 & 0745324 & 3.7 \\
Big Flat Brook & 01439830 & Big Flat Brook at Tuttles Corner, N.J. & 411200 & 0744855 & 28.3 \\
Bush Kill & 01439500 & Bush Kill at Shoemakers, Pa. & 410517 & 0750217 & 117 \\
Dingmans Creek & 01438892 & Dingmans Creek above Dingmans Falls near Dingmans Ferry,Pa. & 411347 & 0745350 & 13.9 \\
Hornbecks Creek & 01439092 & Hornbecks Creek at Emery Road near Dingmans Ferry, Pa. & 411145 & 0745436 & 6.4 \\
Little Bush Kill & 01439680 & Little Bush Kill at Bushkill, Pa. & 410552 & 0750015 & 32.6 \\
Little Flat Br & 01439920 & Little Flat Brook at Peters Valley, N.J. & 411154 & 0745009 & 14.7 \\
Raymondskill Cr & 01438700 & Raymondskill Creek near Milford, PA. & 411811 & 0745121 & 20.4 \\
Sand Hill Creek & 01439570 & Sand Hill Creek at Bushkill, Pa. & 410506 & 0750032 & 3.5 \\
Sawkill Creek & 0143839602 & Sawkill Creek 1000 ft above Mouth at Milford, Pa. & 411900 & 0744759 & 24.7 \\
Shimers Brook & 01438400 & Shimers Brook near Montague, N.J. & 411847 & 0744651 & 7.1 \\
Toms Creek & 01439400 & Toms Creek at Egypt Mills, Pa. & 410733 & 0745720 & 9.3 \\
Vancampens Br & 01440100 & Vancampens Brook near Millbrook, N.J. & 410328 & 0750012 & 7.4 \\
Vandermark Cr & 01438301 & Vandermark Creek at 4th Street at Milford, Pa. & 411930 & 0744749 & 5.2 \\
\hline
\end{tabular}


Table 2. Land-use characteristics of basins associated with water-quality monitoring stations on streams in and near the Delaware Water Gap National Recreation Area, Pa. and N.J., 2002-04.

[Data are from the USGS National Land Cover data for 1992 (U.S. Geological Survey, 2006), after modification by Rachel Riemann (U.S. Forest Service; see discussion in text) to identify low-density urban land use; information indicating the presence of a permitted wastewater facility discharging to basins was obtained from a communication from the New Jersey Department of Environmental Protection (Thomas Cosmas, written commun., 2007) and from information on the Pennsylvania Department of Environmental Protection website accessed April 3, 2007, at http://www.emappa.dep.state.pa.us/emappa/viewer.htm]

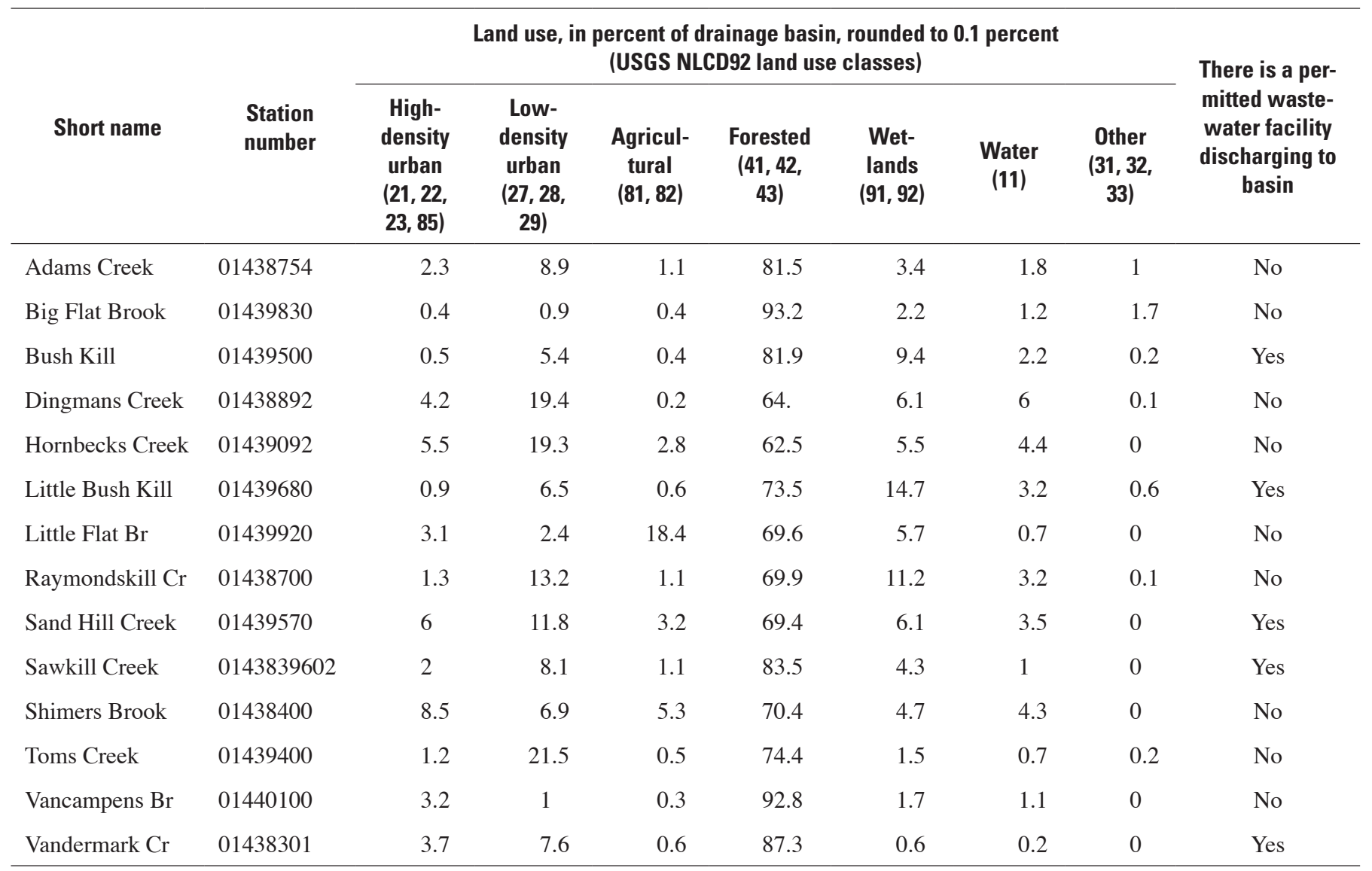

every 4 weeks. During summer (June-September), samples were collected every 2 weeks. At least one additional sample was collected under "stormflow" conditions (during or immediately following rainstorms) each year at each site.

Measurements of plant nutrients and major ions (table 4) were made on composite water samples, which were collected in a 3-liter polyethylene bottle at multiple points across the stream; collection techniques are described by Shelton (1994). The majority of samples for laboratory analysis were collected by personnel wading the stream and using either an open bottle or a DH-81 sampler (Federal Interagency Sedimentation Project, undated); a few samples were collected from a bridge by lowering an open bottle on a line. All equipment was cleaned prior to the collection of each sample.

Subsamples to be sent to the laboratory for determination of concentrations of nutrients and major ions were obtained from the 3-liter bottle after it was shaken. Subsamples for dissolved constituents were filtered through a 0.45 -micrometer membrane filter. All samples were chilled prior to transport to the laboratory.

Two types of quality-assurance/quality-control (QA/QC) samples for plant nutrients and major ions were collectedblanks and replicates. A blank was created by putting deionized water through the equipment used for sample collection, compositing, and filtration. A replicate of a selected environmental sample was obtained by collecting a second environmental sample using the same sampling protocols. Blanks and replicates were processed by the same methods used for environmental samples and then chilled and sent to the laboratory for analyses.

Water temperature, dissolved oxygen, $\mathrm{pH}$, and specific conductance were measured directly in each stream by use of field meters (table 4). The values for water from the center of the stream are reported. All values of dissolved oxygen concentration in this report are expressed as percent of saturation; values are expressed in this way to investigate effects other than temperature on dissolved oxygen. 


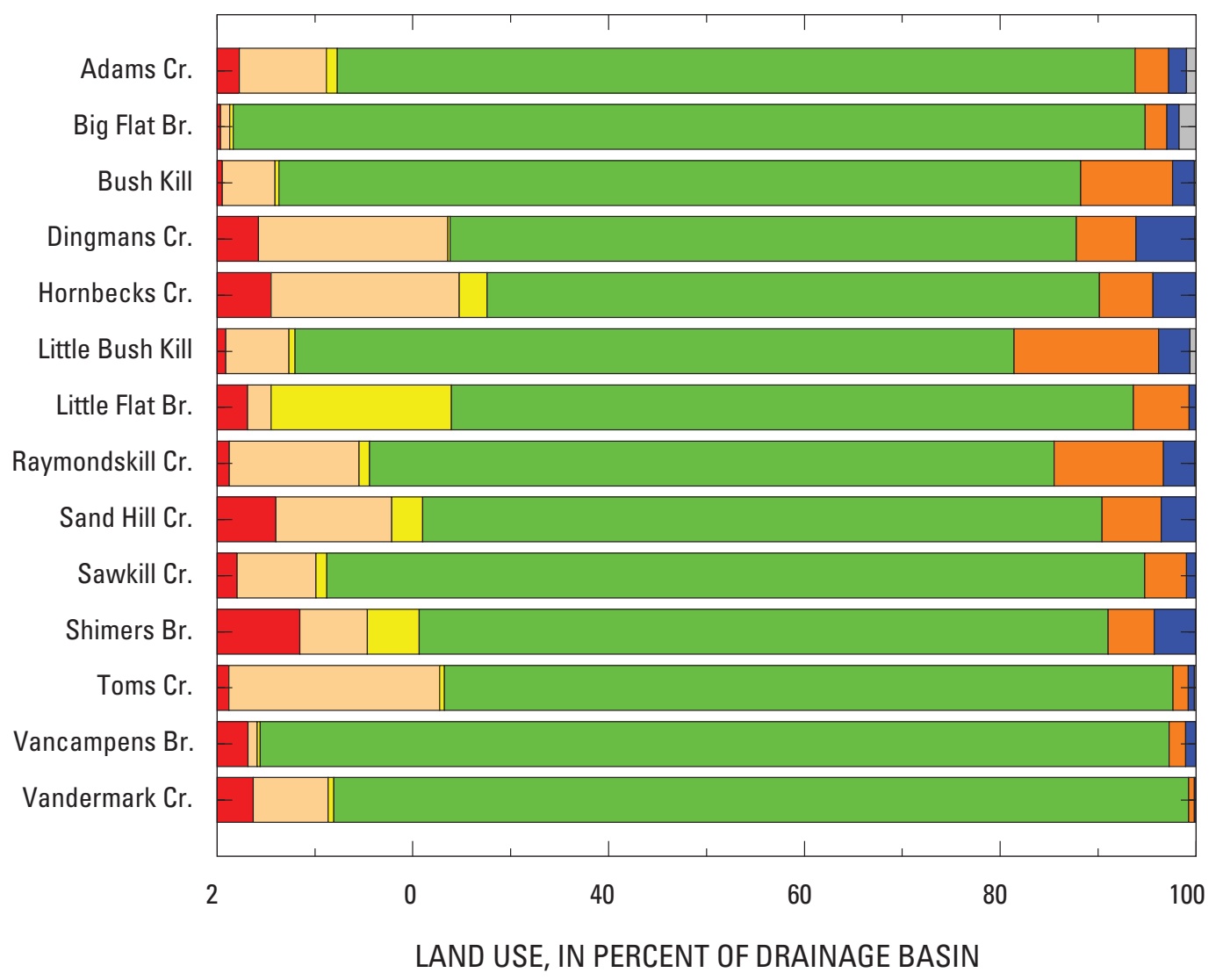

EXPLANATION

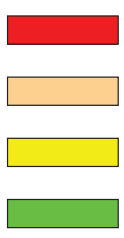

\author{
High-density urban \\ Low-density urban \\ Agricultural
}

Forest

Figure 3. Land use in drainage basins associated with water-quality monitoring stations on streams in and near the Delaware Water Gap National Recreation Area, Pa. and N.J., 2002-04. [Cr., Creek; Br., Brook]

Attenuation turbidity was measured in a sample collected at the center of each stream. Attenuation turbidity values in this report were determined with a LaMotte Colorimeter, which determines turbidity as function of the amount of incident light absorbed by the water sample (LaMotte Company, 1997); the light detector is 180 degrees to the incident light source. This is a nonstandard method to measure turbidity; the standard method is to determine turbidity from measurements of the amount of light scattered at 90 degrees to the incident light source (American Public Health Association, 1998). The values measured by the LaMotte Colorimeter are affected by both the color of the water and the concentration of particles (Tim Parent, LaMotte Company, written commun., 2007). The term "attenuation turbidity" is used throughout this report to remind the reader that these values were collected with a nonstandard method.

Streamflows at the times of sample collection were measured or estimated at 13 of the 14 water-quality monitoring stations; methods are described in appendix 1. Streamflows associated with samples collected from Vandermark Creek at 4th Street at Milford, PA, (station 01438301) were not determined or estimated because this station was added at the last moment prior to sampling and because a site suitable for streamflow measurement could not immediately be found.

Laboratory methods used to analyze the water samples are listed in table 4 . The concentration of each plant nutrient or major ion reported here was determined at the USGS National Water-Quality Laboratory in Denver, Colo. Three types of 
Table 3. Number of measurements of physical characteristics, plant nutrients, major ions, and organic compounds at stations on streams in and near the Delaware Water Gap National Recreation Area, Pa. and N.J., 2002-04.

[Measurements were either made in the field or from laboratory analysis of samples collected in the field]

\begin{tabular}{|c|c|}
\hline Water-quality characteristic & $\begin{array}{l}\text { Average number of } \\
\text { measurements per } \\
\text { station }\end{array}$ \\
\hline \multicolumn{2}{|l|}{ Physical characteristics (including streamflow) } \\
\hline Streamflow & (See Appendix 1) \\
\hline Specific conductance & 43 \\
\hline $\mathrm{pH}$ & 43 \\
\hline Water temperature & 44 \\
\hline Dissolved oxygen, in milligrams per liter & 43 \\
\hline Dissolved oxygen, in percent of saturation & 42 \\
\hline Barometric pressure & 44 \\
\hline Attenuation turbidity & 42 \\
\hline Suspended sediment & 13 \\
\hline \multicolumn{2}{|l|}{ Plant nutrients } \\
\hline Total phosphorus & 44 \\
\hline Dissolved orthophosphate phosphorus & 43 \\
\hline Total nitrogen & 19 \\
\hline Total organic nitrogen plus ammonia & 25 \\
\hline Dissolved ammonia & 43 \\
\hline Dissolved nitrate plus nitrite & 43 \\
\hline Dissolved nitrite & 43 \\
\hline \multicolumn{2}{|l|}{ Major ions } \\
\hline Acid-neutralizing capacity & 18 \\
\hline Dissolved aluminum & 6 \\
\hline Dissolved boron & 18 \\
\hline Dissolved calcium & 18 \\
\hline Dissolved chloride & 18 \\
\hline Dissolved fluoride & 11 \\
\hline Dissolved magnesium & 18 \\
\hline Dissolved silica & 18 \\
\hline Dissolved sodium & 18 \\
\hline Dissolved sulfate & 18 \\
\hline Residue of dissolved constituents upon evaporation & 18 \\
\hline \multicolumn{2}{|l|}{ Organic compounds commonly found in wastewater } \\
\hline $\begin{array}{l}\text { The } 67 \text { compounds, including surfactants and their degradates, food additives, fragrances, anti- } \\
\text { oxidants, flame retardants, plasticizers, industrial solvents, disinfectants, fecal sterols, polycyclic- } \\
\text { aromatic hydrocarbons, and high-use domestic pesticides are listed in Zaugg and others (2002) }\end{array}$ & 1 \\
\hline
\end{tabular}

concentration values were reported; each concentration value consists of a remark code and a numeric value. An uncensored value (remark code is a blank) indicates that the concentration was reliably determined to be greater than or equal to the laboratory reporting level. An estimated value (remark code $=$ "E") indicates that the analyte was detected but could not be reliably quantified by the laboratory. A nondetect value (remark code $=$ " $<$ ") indicates that the concentration is less than the reporting level. For a given constituent, the reporting level sometimes changed during the period of study as a result of changes in methods, reporting protocol, or the presence of substances in the sample that interfered with the results of analysis. 
Table 4. Selected water-quality characteristics measured at stations on streams in and near the Delaware Water Gap National Recreation Area, Pa. and N.J., 2002-04.

[Physical characteristics were measured in the field; measurements of plant nutrients and major ions were determined from laboratory analysis of samples collected in the field; $\mathrm{mg} / \mathrm{L}$, milligrams per liter; $\mathrm{P}$, phosphorus; $\mathrm{N}$, nitrogen; $\mathrm{CaCO}_{3}$; calcium carbonate; $\mathrm{Cl}$, chloride; $\mathrm{Ca}$, calcium; n.a., not applicable]

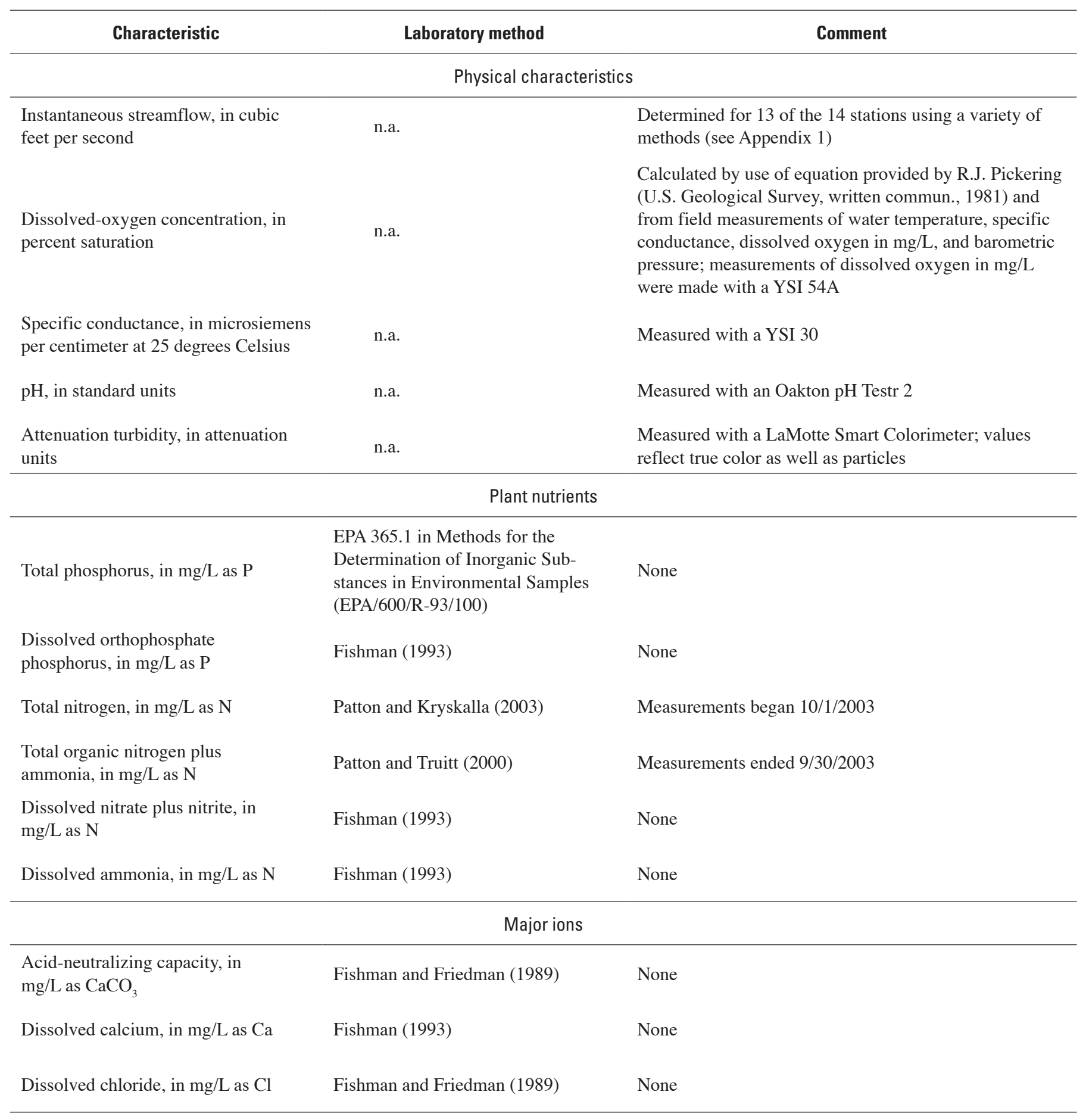




\section{Analyses of Data}

Methods discussed in this section include those used to (1) calculate medians and create boxplots for datasets with nondetect values, and (2) determine if values of physical properties or chemical constituents increased or decreased with changes in streamflow, season, or selected basin characteristics. A method to identify future changes in water quality is presented, and the amount of change which can be detected is discussed.

\section{Modification of Values Reported by Laboratory}

For some of the nutrients and major ions discussed in this report, the USGS National Water Quality Laboratory set reporting levels of nondetect values to twice the method detection limit. This practice was used to minimize the probability of having a false negative and is discussed in Oblinger-Childress and others (1999). According to Helsel (2005), however, this doubling of the detection level produces bias when the values are interpreted. For that reason, the reporting levels for these nondetect values were set back to the method detection level (half the reporting level from the laboratory). This action was suggested by Helsel (2005) as one way to avoid bias in the interpretation of these values.

For samples collected prior to October 1, 2003, concentrations of total nitrogen were calculated by summing concentrations of total organic nitrogen plus ammonia and dissolved nitrate plus nitrite. A reporting level of $0.1 \mathrm{mg} / \mathrm{L}$ for the calculated values of total nitrogen was selected so as to be greater than the reporting levels for total organic nitrogen plus ammonia $(0.05 \mathrm{mg} / \mathrm{L}$ as $\mathrm{N})$ or dissolved nitrate plus nitrite $(0.025$ or $0.03 \mathrm{mg} / \mathrm{L}$ as $\mathrm{N})$ after reporting levels were halved. Below is the set of rules under which values of total nitrogen were calculated.

(1) Estimated concentrations of total organic nitrogen plus ammonia and dissolved nitrate plus nitrite were considered uncensored values.

(2) For the purposes of calculating total nitrogen, nondetect concentrations were set to 0 .

(3) Concentrations of total organic nitrogen plus ammonia and dissolved nitrate plus nitrate were summed.

a) If the sum was greater than or equal to $0.1 \mathrm{mg} / \mathrm{L}$ as $\mathrm{N}$, the concentration of total nitrogen was considered to be uncensored and equal to the sum.

b) If the sum was less than $0.1 \mathrm{mg} / \mathrm{L}$ as $\mathrm{N}$, the concentration of total nitrogen was set to " $<0.1 \mathrm{mg} / \mathrm{L}$ as N."

\section{Calculation of Medians with Nondetect Values}

If nondetect values accounted for less than 50 percent of the set of measurements for a water-quality characteristic at a station, the median of all values was determined without regard to the remark codes. All of these medians were determined to be greater than or equal to the greatest reporting level of the nondetect values.

If nondetect values accounted for 50 to 80 percent of a set of measurements, the median was estimated by use of the regression on order of statistics (ROS) method described in Helsel (2005). Calculations were done with a computer program obtained from the "Practical Statistics for the Sciences" website accessed July 19, 2005, at http://www.practicalstats. com/index.html.

Medians were not estimated for dissolved orthophosphate phosphorus and dissolved ammonia measured for some stations because more than 80 percent of the values were nondetect values. For these stations, the medians are shown as being less than the greatest reporting level of the nondetect values.

\section{Creation of Boxplots with Nondetect Values}

The following rules were used to create boxplots of the measurements of each water-quality characteristic at each station when the measured values included nondetect values.

(1) If 5 percent or less of the set of measurements at all stations were nondetect values, then all values were treated as uncensored.

(2) If more than 5 percent of the set of measurements at any station were nondetect values, then

a) the greatest reporting level of nondetect values at all stations was determined and shown in the figure, and

b) boxplots of values for all stations were censored at this greatest reporting level.

\section{Summary of Water-Quality Values in Blanks and Replicates}

A summary of concentrations of nutrients and major ions in the blanks and replicate/sample pairs (each pair is composed of a replicate and the associated sample) is presented. For blanks, the summary includes the number of blanks in which the compound was detected, the greatest concentration detected, and the greatest reporting level of nondetect concentrations. For replicate/sample pairs, the summary includes (a) the number of replicate/sample pairs with incongruous results and (b) the median and maximum differences between concentrations in replicates and corresponding samples. Incongruous results are considered to exist if a compound was detected in only the sample or in only the replicate, but not in both. Dif- 
ferences between concentrations in replicates and corresponding samples were not calculated for those replicate/sample pairs with incongruous results; a difference between nondetect concentrations in both sample and replicate was recorded as zero.

\section{Relations Between Water-Quality and Basin Characteristics}

The Kendall's tau method (described in Helsel and Hirsch, 1992) was used to determine whether, for a selected water-quality characteristic, median values increased or decreased with increasing values of either (1) land use in the associated drainage basins, or (2) median values of other water-quality characteristics; calculations were done with the Corr procedure (SAS Institute, Inc., 1999a). This nonparametric method measures the strength of monotonic correlation between two variables; an increase or decrease in the selected water-quality characteristic was considered to exist if the level of significance of the correlation was 0.05. Correlations for each water-quality characteristic were calculated with only those stations for which uncensored median concentrations could be calculated.

Some relations identified by use of Kendall's tau were plotted. In each plot, a LOWESS curve shows a smoothed relation between the two variables. The method of calculation of LOWESS curves is briefly described in Helsel and Hirsch (1992).

\section{Equations Relating Water-Quality Characteristics, Streamflow, and Season}

Equations relating values of physical properties or chemical concentrations in a water sample from a station to streamflow and season took one of the two following forms:

$$
\begin{gathered}
C=B_{0}+\left[B_{1} * \log (Q)\right]+ \\
{\left[\left(B_{2} * \sin (0.0172 * j d a y)\right)+\left(B_{3} * \cos (0.0172 * j d a y)\right)\right]}
\end{gathered}
$$

$$
\begin{gathered}
\log (C)=B_{0}+\left[B_{1} * \log (Q)\right]+ \\
{\left[\left(B_{2} * \sin (0.0172 * j d a y)\right)+\left(B_{3} * \cos (0.0172 * j d a y)\right)\right]}
\end{gathered}
$$

where

$$
\begin{aligned}
\log = & \text { base-10 logarithm; } \\
C= & \text { value of selected physical property or } \\
& \text { chemical concentration; } \\
B_{0}= & \text { intercept; } \\
B_{1}= & \text { coefficient for logarithm of streamflow; } \\
Q \quad= & \text { streamflow, in cubic feet per second; }
\end{aligned}
$$

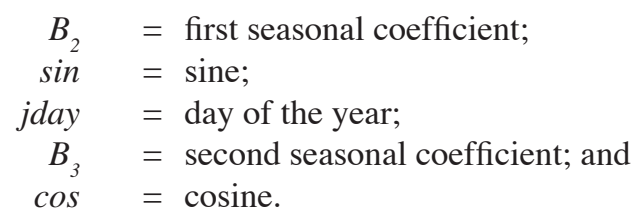

For each water-quality characteristic, the selection of whether to use equation 1 or equation 2 to relate water-quality values to streamflow and season was based on an examination of the plot of the data. Equation 1 was selected for dissolved oxygen concentration and $\mathrm{pH}$; equation 2 was selected for all other water-quality characteristics.

The sine and cosine terms in equations 1 and 2 are the seasonal terms. The form of the seasonal terms was taken from Helsel and Hirsch (1992); two seasonal terms are needed to define the amplitude and the phase shift of the relation between water-quality characteristic and season.

Equations were developed by use of Tobit regression (briefly described in appendix 2) rather than least-squares regression, because in equations 1 and 2, Tobit regression allows the water-quality values to be nondetect values. If all values of a water-quality characteristic are detected, the results of Tobit regression are the same as for least-squares regression.

Equations were not developed if more than 80 percent of the measured values were "non-detects" and if there were fewer than 12 detected values. These requirements (that 20 percent of the water-quality values should be detected and that three or more detected values for each coefficient including the intercept were available) were suggested by David Lorenz (U.S. Geological Survey, written commun., 2007).

Equations were not reported if the assumptions of linearity, normality, and constant variance were not met. Linearity, constant variance, and normality of the data were verified by examining plots of data and residuals. How well the values predicted with each equation matched measured values was determined from an examination of plots of predicted and measured values as a function of streamflow and season. The effect of outlying points was considered. Plots of residuals as a function of streamflow and season were examined to determine whether there was constant variance. Probability plots of residuals were examined to determine if the residuals were normally or near normally distributed.

For 13 of the 14 stations, streamflow values were those instantaneous values measured or estimated at the time of sampling at the stations. The daily mean streamflows at Flat Brook near Flatbrookville, N.J., (01440000) on the days of sample collection were used in place of streamflows at the station on Vandermark Creek (01438301). No analysis was made to determine whether the daily streamflow in Flat Brook was representative of streamflow in Vandermark Creek.

\section{Variation of Water Quality with Streamflow}

Whether the value of a physical property or chemical constituent changed with increasing streamflow was deter- 
mined from the value of $B_{l}$ in either equation 1 or equation 2 . An increase was considered to exist if $B_{1}$ was greater than 0 at a 0.05 level of significance; a decrease was considered to exist if $B_{1}$ was less than 0 at a 0.05 level of significance.

\section{Variation of Water Quality with Season}

A nested F-test (described in Helsel and Hirsh, 1992) was used to determine whether the value of a physical property or chemical constituent varied with season for reasons other than the seasonal variation of streamflow. The outcome of the test was used to determine whether a "complex" equation with seasonal terms was significantly better than a "simple" equation without seasonal terms in explaining the variation in the values of a water-quality characteristic at a station. The "complex" equations are equations 1 and 2 previously discussed. The corresponding "simple" equations are

$$
C=B_{0}+B_{1}(\log (Q))
$$

and

$$
\log (C)=B_{0}+B_{1}(\log (Q))
$$

where

$$
\begin{aligned}
\log = & \text { base-10 logarithm; } \\
C & =\text { value of selected water-quality } \\
& \text { characteristic; } \\
B_{0}= & \text { intercept; } \\
B_{1}= & \text { coefficient for logarithm of } \\
& \text { streamflow; and } \\
Q \quad= & \text { streamflow, in cubic feet per second. }
\end{aligned}
$$

One equation was used for all relations for each waterquality characteristic. Equation 3 was used for dissolved oxygen concentration and $\mathrm{pH}$. Equation 4 was used all other water-quality characteristics.

The following equation for a nested F-test was taken from Helsel and Hirsch (1992).

$$
F=\frac{\left(S S E_{s}-S S E_{c}\right) /\left(d f_{s}-d f_{c}\right)}{\left(S S E_{c} / d f_{c}\right)},
$$

where

$$
\begin{aligned}
F= & \text { test statistic, } \\
S S E_{s} \quad= & \text { sum of squares of errors for simple } \\
& \text { equation } 3 \text { or } 4, \\
S S E_{c} \quad= & \text { sum of squares of errors for complex } \\
& \text { equation } 1 \text { or } 2, \\
d f_{s}= & \text { degrees of freedom of simple model, and } \\
d f_{c}= & \text { degrees of freedom of complex model. }
\end{aligned}
$$

The degrees of freedom of the simple model and complex model are defined as

$$
d f_{s}=n-2,
$$

and

$$
d f_{c}=n-4,
$$

where

$$
\begin{aligned}
d f_{s} & =\text { degrees of freedom of simple model } \\
d f_{c} & =\text { degrees of freedom of complex model, and } \\
n & =\text { number of measurements in model. }
\end{aligned}
$$

Equation 5, however, is formulated for use with leastsquares regression and was modified for use with Tobit regression by substituting values of "scale" (see Appendix 2) in place of values of sum of squares of error by use of equation 8:

$$
S S E \approx \operatorname{scale}^{2} \times d f,
$$

where

$$
\begin{aligned}
\text { SSE } & =\text { sum of squares of error, } \\
\text { scale } & =\text { measure of "goodness of fit" from Tobit } \\
& \text { regression, and } \\
d f \quad= & \text { degrees of freedom. }
\end{aligned}
$$

Substituting equations 6 to 8 into equation 5 produces the equation given below. It is this equation that was used to determine the value of the test statistic F-test with Tobit regression.

$$
F=\frac{\left(\left(\text { scale }_{s}^{2} \times(n-2)\right)-\left(\text { scale }_{c}^{2} \times(n-4)\right)\right) /(2)}{\text { scale }_{c}^{2}},
$$

where

$$
\begin{aligned}
F & =\text { test statistic, } \\
\text { scale }_{s} & =\text { scale for simple equation } 3 \text { or } 4, \\
\text { scale }_{c} & =\text { scale for complex equation } 1 \text { or } 2, \text { and } \\
n & =\text { number of measurements. }
\end{aligned}
$$

For this report, the complex model was considered to be significantly better than the simple model in describing the variation of the water-quality values if the test statistic $(F)$ equaled or exceeded the value of the $\mathrm{F}$ distribution with 2 and $d f_{c}$ degrees of freedom at a 0.05 level of significance. In these cases, the values of water quality were considered to vary with season.

\section{Detection of Future Changes in Water Quality}

Differences between current and future values of a waterquality characteristic are based on equations between values of that water-quality characteristic at a station, streamflow, and season. Separate equations are developed by use of Tobit regression for values of current water quality and water quality to be measured in the future. The form of the equation for 
a selected water-quality characteristic at a station is shown either by equation 1 or equation 2 .

Differences between current and future values of a waterquality characteristic at a station are based on a comparison of the intercepts in the two equations. The method of comparison of intercepts was provided by Gregory Schwarz (U.S. Geological Survey, written commun., 2005). The comparison is based on the following equation:

$$
t=\left(B_{o p}-B_{o f}\right) /[\operatorname{var}(\operatorname{delta}(\text { intercepts }))]^{0.5},
$$

where

$$
\begin{aligned}
& t=\text { test statistic, } \\
& B_{0 p} \quad=\text { intercept of relation with current } \\
& \text { values of a water-quality characteristic at a } \\
& \text { station, } \\
& B_{\text {of }} \quad=\text { intercept of relation with future value of a } \\
& \text { water-quality characteristic at a station, and } \\
& \operatorname{var}(\text { delta }(\text { intercepts }))=\text { variance of the difference }
\end{aligned}
$$

The two intercepts will be known, but the variance of the differences between intercepts will not. The variance term, however, can be approximated from the number of measurements of current and future water quality and the variance of the errors in the relation for current water quality using the equation

$$
\begin{gathered}
\operatorname{Var}(\text { delta }(\text { intercepts })) \approx((m+n) / \\
(m * n))(\operatorname{Var}(\text { errors })),
\end{gathered}
$$

where

$$
\begin{aligned}
& \text { Var (delta }(\text { intercepts }))=\text { variance of the } \\
& \text { difference between intercepts, } \\
& \begin{aligned}
& m \quad= \text { number of current measurements, } \\
& n \quad= \text { number of future measurements, and } \\
& \operatorname{Var}(\text { errors })=\text { variance of the errors in the } \\
& \text { relation with current water quality. }
\end{aligned}
\end{aligned}
$$

In turn, the variance of the errors of the relation can be approximated with the mean square error of the relation with current water quality using the equation

$$
\operatorname{Var}(\text { errors }) \approx M S E,
$$

where

$$
\begin{aligned}
\operatorname{Var}(\text { errors })= & \text { variance of the errors in the relation, } \\
& \text { and } \\
M S E= & \text { mean square error of relation with current } \\
& \text { water quality. }
\end{aligned}
$$

If values in equations 11 and 12 are substituted in equation 10 and scale is substituted for mean square error, equation 13 is the result. This equation can be used to determine whether the intercepts are significantly different from one another. All values on the right hand side will be known after the future sampling.

$$
t \approx\left(B_{o p}-B_{o f}\right) /\left[((m+n) /(m * n))\left(\text { scale }^{2}\right)\right]^{0.5},
$$

where

$$
\begin{aligned}
t= & \text { test statistic, } \\
B_{0 p}= & \text { intercept of relation with current water } \\
& \text { quality, } \\
B_{0 f}= & \text { intercept of relation with future water } \\
& \text { quality, } \\
m= & \text { number of current measurements, } \\
n= & \text { number of future measurements, and } \\
\text { scale }= & \text { measure of "goodness of fit" from Tobit } \\
& \text { regression relation with current water } \\
& \text { quality. }
\end{aligned}
$$

The value of $t$ is calculated using equation 13 , then compared to the value of $t_{\text {crit }}$ which is the value of the $t$ distribution for $\mathrm{df}_{\text {crit }}$ degrees of freedom and a 0.05 level of significance. The value for $\mathrm{df}_{\text {crit }}$ is calculated using the equation

$$
d f_{c r i t}=(m+n-3)
$$

where

$$
\begin{aligned}
d f_{\text {crit }} & =\text { degrees of freedom } \\
m & =\text { number of current measurements, and } \\
n & =\text { number of future measurements. }
\end{aligned}
$$

If the value of $t$ equaled or exceeded the value of $t_{\text {crit }}$, the two intercepts are considered to be different, and water quality of the future is considered to be different than the current water quality.

The amount of change that can be detected in the intercept of the equation with current water quality can be estimated. Equation 13 can be rearranged into equation 15, from which the amount of change in intercept with current water quality can be detected.

$$
\left.\left(B_{o p}-B_{o f}\right) \approx\left(t_{c r i t}\right) *\left[((m+n) /(m * n)) *\left(\text { scale }^{2}\right)\right]\right]^{0.5},
$$

where

$$
\begin{aligned}
B_{0 p}= & \text { intercept of relation with current water } \\
& \text { quality, } \\
B_{0 f}= & \text { intercept of relation with future water } \\
& \text { quality, } \\
t_{c r i t}= & \text { value of t distribution for given degrees } \\
& \text { of freedom of complex model and a } 0.05 \\
& \text { level of significance, } \\
m= & \text { number of current measurements of water } \\
& \text { quality, } \\
= & \text { number of future measurements of water } \\
& \text { quality, and } \\
= & \text { measure of "goodness of fit" from Tobit } \\
\text { scale } & \text { regression relation with current water } \\
& \text { quality. }
\end{aligned}
$$


For a relation in which the value of the water-quality characteristic is untransformed, the change in intercept which can be identified is

$$
\text { delta }=\left[\left(B_{0 f}-B_{0 p}\right) /\left(B_{O p}\right)\right] * 100,
$$

where

$$
\begin{aligned}
\text { delta } & =\text { change in intercept with current water } \\
& \text { quality, in percent; } \\
B_{o_{p}} & =\text { intercept in relation with current water } \\
& \text { quality; and } \\
B_{o f} & =\begin{array}{l}
\text { intercept in relation with future water } \\
\text { quality. }
\end{array}
\end{aligned}
$$

For a relation in which the value of the water-quality characteristic is expressed as a logarithm, the change in intercept which can be identified is

$$
\text { delta } \approx\left(\exp \left(B_{0 f}-B_{0 p}\right)-1\right) * 100
$$

where

$$
\begin{aligned}
\text { delta } & =\text { change in intercept with current water } \\
& \text { quality, in percent; } \\
\exp & =\text { exponent; } \\
B_{o p} & =\text { intercept in relation with current water } \\
& \text { quality; and } \\
B_{o f} & =\begin{array}{l}
\text { intercept in relation with future water } \\
\end{array} \\
& \text { quality. }
\end{aligned}
$$

As an alternative to the comparison of intercepts, the nonparametric seasonal rank sum test (described in Helsel and Hirsch, 1992, p. 118 and 348) can also be used to determine if the values of water-quality characteristics measured in the future are, as a group, different from the values measured during 2002-04. This method, which compares the relative magnitudes of the two sets of values, does not require the values to be normally distributed and can incorporate nondetect values. The variation of water quality with season is considered.

If only a small fraction of the current and future values of a water-quality characteristic are nondetects, the effects of season and streamflow can be incorporated into the rank sum test. A LOWESS curve between all values (current and future) of a water-quality characteristic and streamflow is created. Then a seasonal rank-sum test determines whether the residuals from the LOWESS curve for future measurements are different from the residuals for 2002-04 measurements.

\section{Water Quality of Streams in and near the Delaware Water Gap National Recreation Area, 2002-04}

Water-quality characteristics discussed in this report were selected for two reasons. Some characteristics (such as phosphorus and nitrogen species) were selected because values of these characteristics are expected to change with increasing urbanization and because the differences in current land use among the drainage basins may help explain the station-tostation differences in current values. Other characteristics (such as calcium) were selected because the station-to-station differences in values of these characteristics are related to differences in the geology of the basins.

\section{Summary of Water-Quality Characteristics at Each Station}

Summary statistics for the values of water-quality characteristics at each station are shown in appendix 3, and boxplots showing the distribution of values of most water-quality characteristics are shown in figure 4. Boxplots of dissolved ammonia and dissolved orthophosphate phosphorus are not shown because the greatest reporting levels of nondetect values for these two characteristics were greater than most of the detected concentrations; as a result, little information would be displayed. Boxplots of the concentrations of total nitrogen and dissolved nitrate plus nitrite are censored because, at Vancampens Brook (station 01440100), 28 percent of the concentrations of total nitrogen and 59 percent of the concentrations of dissolved nitrate plus nitrite are nondetects.

Only those concentrations of dissolved oxygen (as percent of saturation) measured during the months of July, August, and September were used in the analyses because station-to-station differences in concentrations, as well as variations with streamflow, were expected to be more apparent if only these values were considered. The higher temperatures during July through September, relative to temperatures in the other months, tend to increase the rate and effects of the chemical and biological processes that either increase or decrease the amount of oxygen dissolved in the water. In addition, the effects of the processes that add or remove oxygen from the water are more pronounced or evident during the relatively low streamflow during July through September than during periods of higher streamflow.

\section{Results of Analyses of Blanks and Replicates}

For most major ions and plant nutrients, the results from analyses of blanks indicate that effects of contamination from sample-collection and sample processing equipment on concentrations appear negligible (table 5). Dissolved orthophosphate phosphorus, total nitrogen, organic nitrogen plus ammo- 
(A)
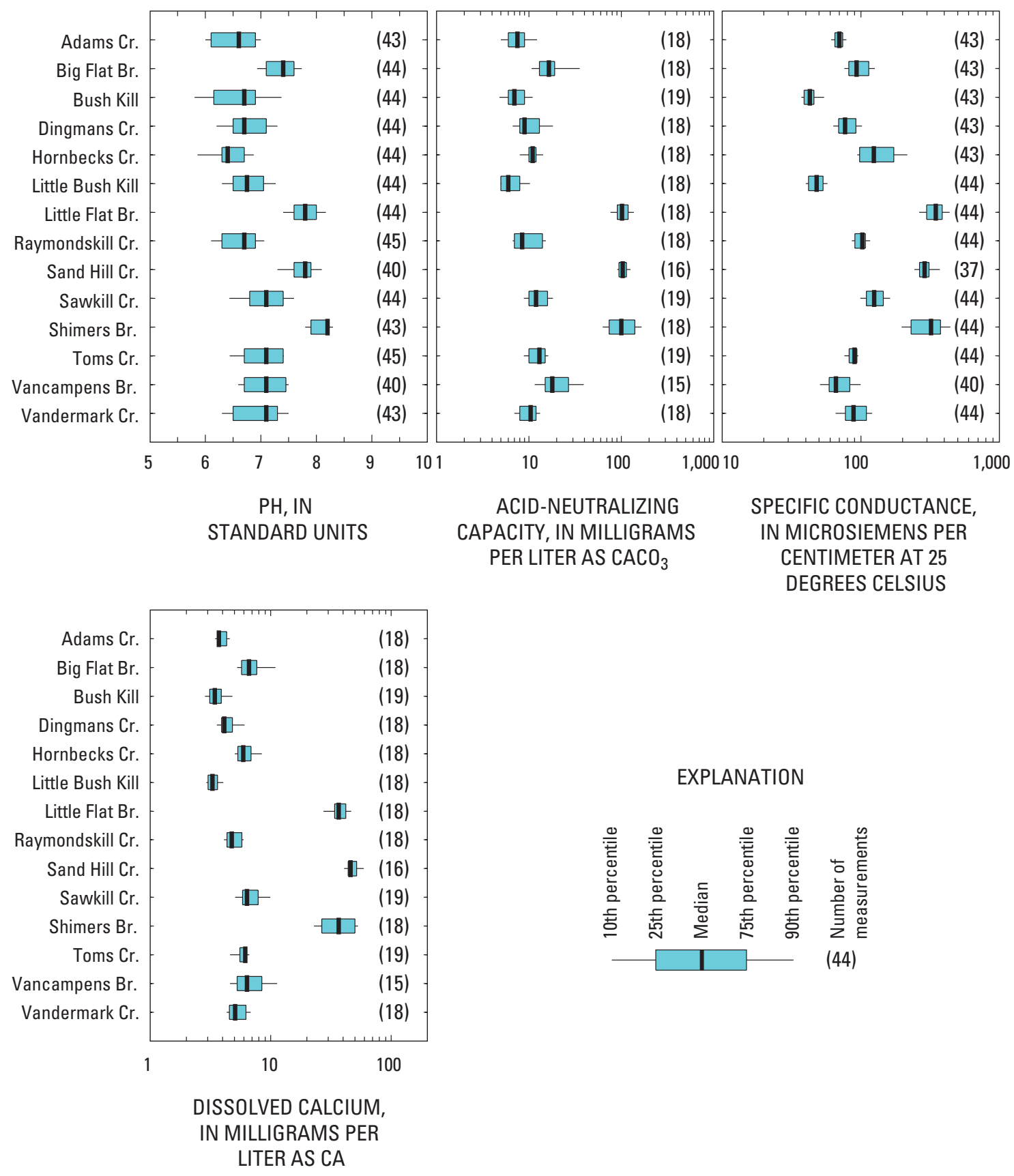

Figure 4. Distribution of values of $(A) \mathrm{pH}$, acid-neutralizing capacity, specific conductance, dissolved calcium, $(B)$ attenuation turbidity, total phosphorus, dissolved oxygen, total nitrogen, dissolved nitrate plus nitrite, and dissolved chloride at each water-quality monitoring station on streams in and near the Delaware Water Gap National Recreation Area, Pa. and N.J., 2002-04. 
(B)

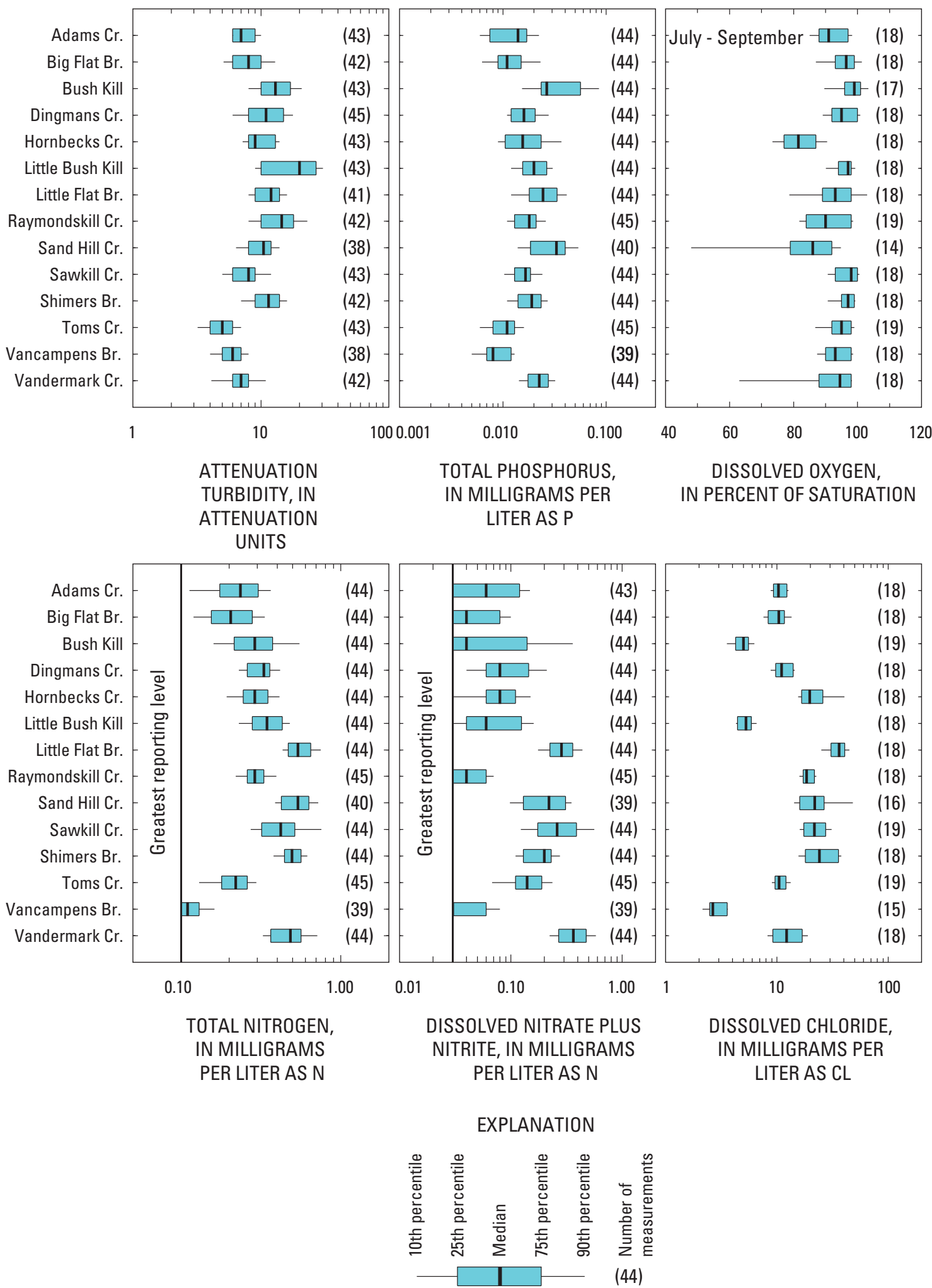

Figure 4. Distribution of values of $(A) \mathrm{pH}$, acid-neutralizing capacity, specific conductance, dissolved calcium, $(B)$ attenuation turbidity, total phosphorus, dissolved oxygen, total nitrogen, dissolved nitrate plus nitrite, and dissolved chloride at each water-quality monitoring station on streams in and near the Delaware Water Gap National Recreation Area, Pa. and N.J., 2002-04.—Continued 
nia, dissolved nitrate plus nitrite, and dissolved chloride were not detected in any blank.

For total phosphorus and dissolved ammonia, the effects of contamination appear to exist but are small. Total phosphorus was detected in 2 of 14 blanks, and dissolved ammonia was detected in 1 of 14 blanks (table 5); detected concentrations of each were near the respective reporting levels.

Dissolved calcium was detected in three of seven blanks (table 5). The effect of this apparent contamination is negligible, however. The greatest detected concentration was 0.01 $\mathrm{mg} / \mathrm{L}$ as $\mathrm{Ca}$, two orders of magnitude lower than the smallest concentration in any environmental sample (about $2 \mathrm{mg} / \mathrm{L}$ as Ca).

Acid-neutralizing capacity was detected in four of seven blanks at concentrations near the reporting level (table 5). These detections could indicate contamination. However, they may also indicate that the laboratory reporting level during the study (1-2 $\mathrm{mg} / \mathrm{L}$ as $\mathrm{CaCO}_{3}$ ) was set too low and that concentrations at the reporting level, either in blanks or in samples, are not accurate. In 2005, the National Water Quality Laboratory raised the reporting limit of acid-neutralizing capacity to $5 \mathrm{mg} / \mathrm{L}$ as $\mathrm{CaCO}_{3}$.

The summary of analyses of replicate/sample pairs (table 5) provides information for each characteristic on the differences between concentrations in replicates and associated samples in each replicate/sample pair. Each replicate constitutes a measurement of the water quality of a stream separated in time by a few minutes from the associated sample. Differences between concentrations in replicates and concentrations in the associated samples can be the result of changes in the concentrations in the stream between the time the sample was collected and the time the replicate was collected, but may also be the result of variations in methods of sample collection, processing, and (or) laboratory analysis.

The differences between concentrations in replicates and concentrations in associated samples provide a measure of the variability in concentrations in all samples collected as part of this sampling program that are due to these three factors. Variability in detection and variability in concentration were considered separately.

A measure of the variation in detection of each characteristic is indicated by examining the percentage of replicate/ sample pairs with incongruous results. The characteristics with the largest percentage of replicate/sample pairs with incongruous results tend to be those with the smallest number of detected values (and, therefore, the smallest concentrations relative to the reporting limits) in the samples of the replicate/ sample pairs (table 5). Dissolved ammonia is the characteristic with the most replicate/sample pairs with incongruous results (12 percent of pairs) and the fewest number of detections in the samples of the replicate/sample pairs (38 percent). In contrast, the characteristics with no incongruous results (total phosphorus, total nitrogen, dissolved calcium, and acid-neutralizing capacity) were detected in 100 percent of the samples of the replicate/sample pairs.
A measure of the variation in concentration for each characteristic is indicated by comparing concentrations in samples with concentrations in associated replicates. The variability in concentration appears to be affected by whether or not the concentration is for characteristics in dissolved form or dissolved plus particulate form. The greatest median differences (in terms of percentages of sample concentration) were for total phosphorus ( 8 percent), total nitrogen ( 7 percent), and total organic nitrogen plus ammonia (20 percent). All these plant nutrients are in dissolved plus particulate form. For plant nutrients in the dissolved form only, the median differences were less than 1 percent.

Two reasons are proposed to account for the greater variability in concentration, when characteristics are composed, at least partly, of particulate substances compared with those composed only of dissolved substances. First, the variation in concentration in the stream over short periods of time may be greater for particulate substances than for dissolved substances. Second, the method of creating subsamples from each composited sample (shaking and pouring from the compositing bottle) could have created subsamples with non-representative concentrations of particulate substances because the particles were not distributed evenly.

\section{Variation of Water Quality with Basin Characteristics}

It is apparent from the boxplots in figure 4 that values of a selected water-quality characteristic varied from stream to stream. For example, the median concentration of total phosphorus at the station on Sand Hill Creek (0.033 milligrams per liter as $\mathrm{P}$ ) was four times the corresponding median concentration at the station on Vancampens Brook (0.008 milligrams per liter as P). This variation can be attributed to differences in land-use and geology of the drainage basins, as well as to the presence of wastewater discharges to the basins.

Results of correlations between median values of waterquality characteristics at the stations and the amounts of highintensity and low-intensity urban land, agricultural land, and wetlands are given in table 6 . Relations for most water-quality characteristics were determined from medians from all 14 stations; relations for dissolved orthophosphate phosphorus and dissolved ammonia were determined from medians at 12 and 9 stations, respectively.

In all relations identified, median concentrations increased with increasing amounts of a specified land use (table 6). In no relations did median concentrations decrease with increasing amounts of any of the specified land uses.

For the two phosphorus and three nitrogen species, results of correlations between median concentrations of these plant nutrients and land use at all stations indicate that agricultural land appears to have a greater effect on water quality than either high-intensity or low-intensity urban land when all 14 stations are considered (table 6). Median concentrations of total nitrogen and dissolved nitrate plus nitrite increased with 


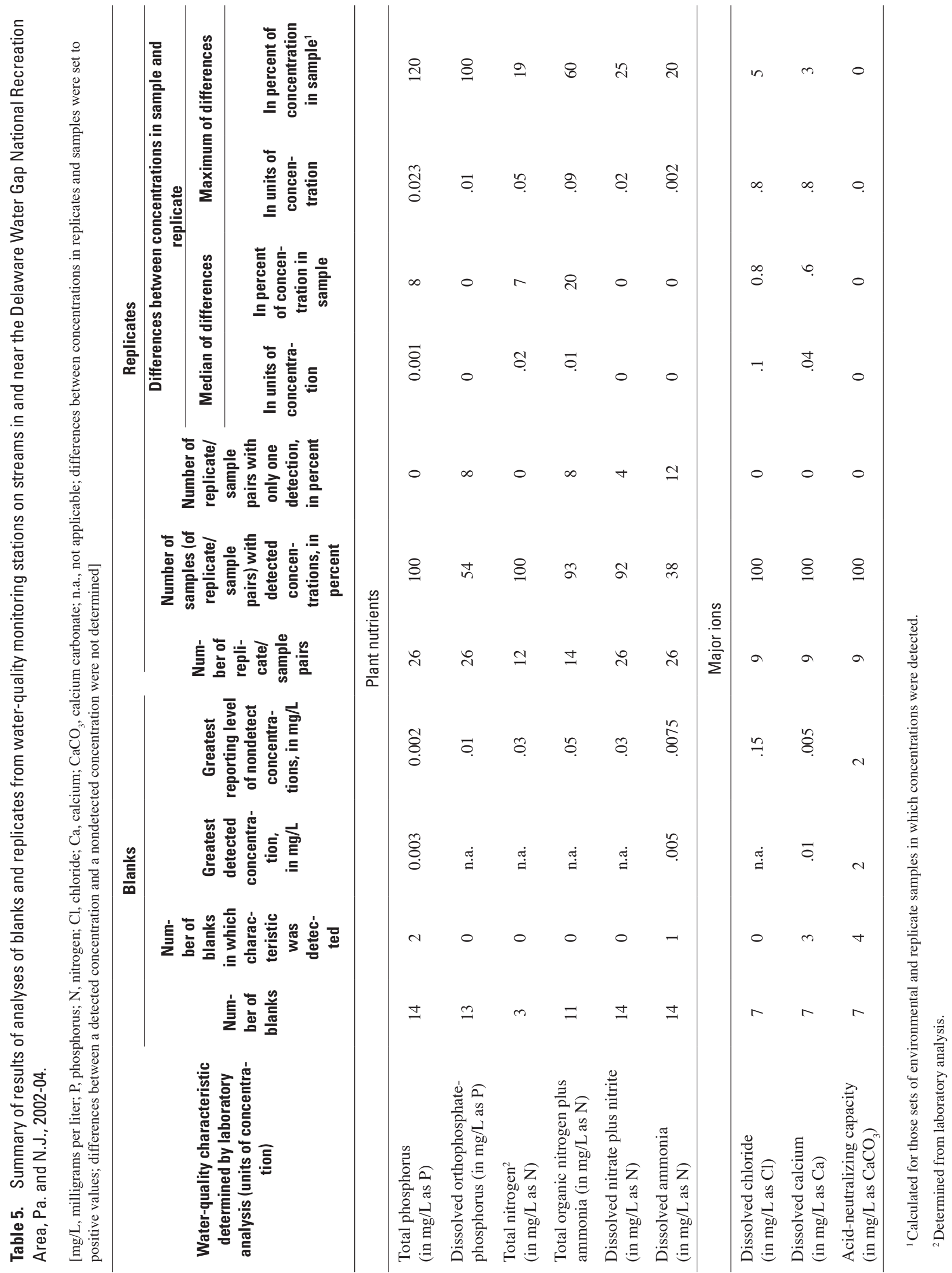


Table 6. Results of correlation tests between median values of water-quality characteristics at each water-quality monitoring station and the land use in the drainage basin, for streams in and near the Delaware Water Gap National Recreation Area, Pa. and N.J., 2002-04.

$[+$, median increased with increasing land use at a 0.05 level of significance; --, no significant correlation; $<$, less than $]$

Water-quality characteristic Results of Kendall tau tests to determine whether median value of the water-quality characteristic
increased or decreased with increasing land use in drainage basin (level of significance)

\begin{tabular}{|c|c|c|c|c|}
\hline & $\begin{array}{l}\text { High-intensity } \\
\text { urban land }\end{array}$ & $\begin{array}{l}\text { Low-intensity } \\
\text { urban land }\end{array}$ & Agricultural land & Wetlands \\
\hline \multicolumn{5}{|c|}{ Physical characteristics } \\
\hline $\begin{array}{l}\text { Dissolved oxygen concentration } \\
\text { (July-September) }\end{array}$ & -- & -- & -- & -- \\
\hline Specific conductance & -- & -- & $\stackrel{+}{+}$ & -- \\
\hline $\mathrm{pH}$ & -- & -- & -- & -- \\
\hline Attenuation turbidity & -- & -- & -- & $\stackrel{+}{+} \underset{(<0.0001)}{ }$ \\
\hline \multicolumn{5}{|c|}{ Plant nutrients } \\
\hline Total phosphorus & -- & -- & -- & $\stackrel{+}{+}+(0.028)$ \\
\hline Dissolved orthophosphate phosphorus ${ }^{1}$ & -- & -- & -- & -- \\
\hline Total nitrogen & -- & -- & $\begin{array}{l}+ \\
(0.01)\end{array}$ & -- \\
\hline Dissolved nitrate plus nitrite & -- & -- & $\begin{array}{c}+ \\
(0.027)\end{array}$ & -- \\
\hline Dissolved ammonia $^{2}$ & -- & -- & -- & -- \\
\hline \multicolumn{5}{|c|}{ Major ions } \\
\hline Acid-neutralizing capacity & -- & -- & -- & -- \\
\hline Dissolved calcium & -- & -- & -- & -- \\
\hline Dissolved chloride & $\stackrel{+}{+}$ & -- & $\stackrel{+}{+}$ & -- \\
\hline
\end{tabular}

${ }^{1}$ Only the uncensored medians at 12 stations were included in the analysis.

${ }^{2}$ Only the uncensored medians at 9 stations were included in the analysis.

an increase in the area of agricultural land in the associated basin, but not with increases in the areas of either highintensity or low-intensity urban land. Similar results for total nitrogen and dissolved nitrate plus nitrite can be attributed to the fact that total nitrogen is composed partly of nitrate plus nitrite; median concentrations of total nitrogen as a function of agricultural land use are shown in figure 5. No relations between either phosphorus species and agricultural land or high-intensity or low-intensity urban land were identified.

An examination of figure 5 indicates that the presence of a permitted wastewater facility in a basin appears to be a factor affecting median concentrations of total phosphorus and total nitrogen in the streams. For a specified amount of agri- cultural land in a basin, concentrations at stations with permitted wastewater facilities in the basin appear to be greater than concentrations at stations without such facilities in the basin.

To provide clearer relations between water quality and land use without effects of permitted wastewater discharge, selected correlations indicated in table 6 were repeated without the 5 stations in basins with permitted wastewater facilities (table 2). The results of these correlations are described below.

When only the nine stations with no permitted wastewater facilities are considered, median concentrations of both total phosphorus and total nitrogen increased with an increase in the area of agricultural land use in the associated basin (fig. 5); each relation has a 0.01 level of significance. These 


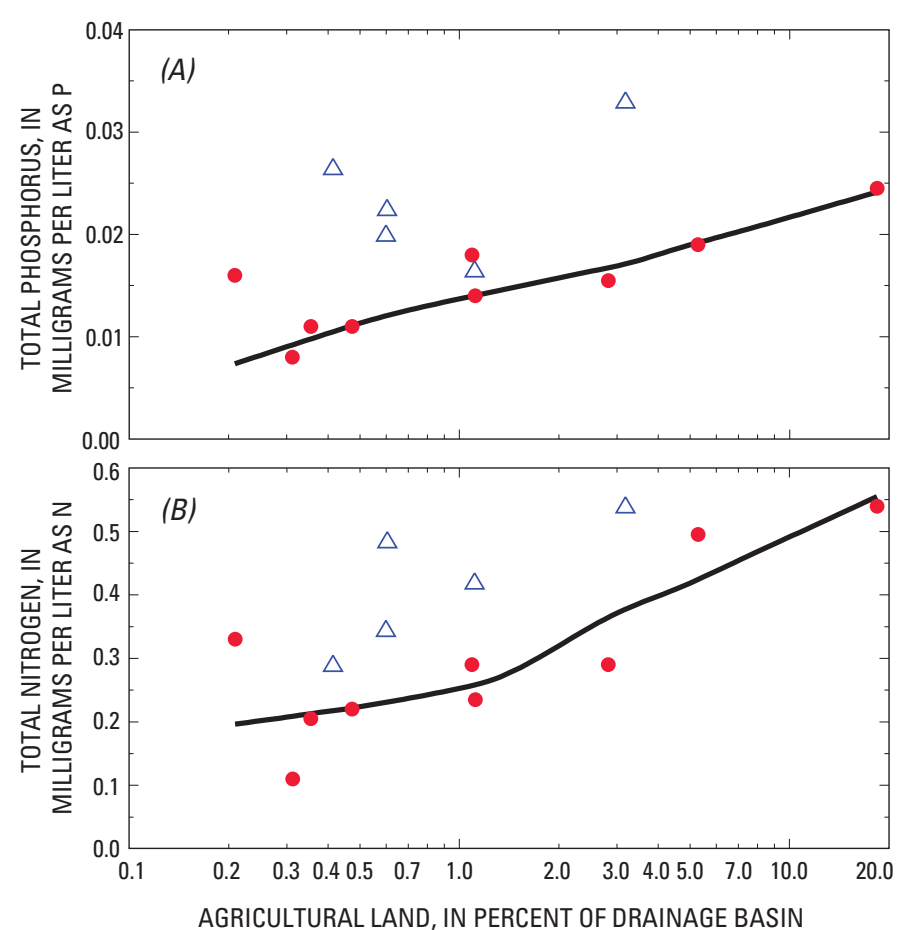

EXPLANATION

\section{LOWESS smoothed curve through median concentrations at stations with no permitted wastewater facility \\ - Median concentration at a station with no permitted wastewater facility \\ $\triangle \quad$ Median concentration at a station with a permitted wastewater facility}

Figure 5. Median concentrations of $(A)$ total phosphorus and (B) total nitrogen at water-quality monitoring stations as a function of agricultural land use and the presence of permitted wastewater facilities in associated drainage basins, for streams in and near the Delaware Water Gap National Recreation Area, Pa. and N.J., 2002-04.

patterns indicate that agricultural land use could be an important factor affecting the concentrations of both plant nutrients where no permitted wastewater discharges are present. The importance of agricultural land as a factor in streamwater quality has been discussed previously.

When all stations are considered, the area of wetlands in a basin does not appear to be a major factor related to median concentrations of phosphorus and nitrogen species. Of the two phosphorus and three nitrogen species, relations between median concentration and the area of wetlands in a basin were only identified for total phosphorus (table 6); median concentrations of total phosphorus increased with increasing area of wetlands (level of significance is 0.028).

When only the seven stations in basins with (a) no permitted wastewater facility and (b) agricultural land use accounting for less than 5 percent of the basin were consid- ered, median concentrations of both total phosphorus and total nitrogen increased with the increasing area of wetlands in the basin (fig. 6). The level of significance for the relation for total phosphorus is 0.003 , and the relation for total nitrogen is 0.03 . The two stations with more than 5 percent agricultural land within the basin, but with no permitted wastewater discharge (Shimers Brook and Little Flat Brook), were not included in the analysis to minimize the effects of agriculture on the relation between water quality and wetland area.

Little information is available in the literature about yields of phosphorus and nitrogen from wetlands. Wetlands are commonly considered as sinks for phosphorus and nitrogen that enter in streamflow (Mitsch and Gosselink, 1986, table 5-8). Nevertheless, Dillon and Molot (1997) report that the concentrations of phosphorus in streamflow leaving mostly forested basins in Ontario, Canada, increased with an increasing fraction of the basin composed of wetlands; they attributed this result to the complexation (facilitated by iron) of phosphorus with dissolved organic carbon. Whether the processes described for the forested basins in Ontario occur in the basins of streams tributary to the DWGNRA is unknown. No similar report comparing nitrogen yields from wetlands and forested basins could be found.

The small percentages of agricultural and wetland area in the drainage basin of Vancampens Brook (station 01440100) could be one reason why the median concentrations of total phosphorus, total nitrogen, and dissolved nitrate plus nitrite for this station were the smallest of those for all stations (fig. 4). The basin draining to this station has the second smallest area of agricultural land and wetlands of any basin considered.

From figure 6, the presence of a permitted wastewater facility that discharges into the drainage basin appears to affect the concentrations of total phosphorus and total nitrogen in streamflow leaving some, but not all, basins receiving such discharges. Median concentrations of total phosphorus at three of the five stations with permitted discharges - Vandermark Creek (station 01438301), Sand Hill Creek (station 01439570), and Bush Kill (station 01439500) - were noticeably greater than the median concentrations at stations with no permitted discharges and with less than 5 percent agricultural land in the basin. Also, from examination of the graph in figure 6 , median concentrations of total nitrogen at three of the five stations with permitted discharges - Vandermark Creek (station 01438301), Sand Hill Creek (station 01439570), and Sawkill Creek (station 0143839602) - were noticeably greater than median concentrations at stations with no permitted discharges and with less than 5 percent agricultural land in the basin.

The high median concentrations of nutrients at stations with permitted wastewater discharge (figs. 5 and 6) could be due to the effects of wastewater discharged directly to the streams. Some of wastewater facilities are septic systems, however, and the high concentrations could be the result of ground water leaving the septic systems and discharging to streams. Lastly, the high concentrations also could reflect the 

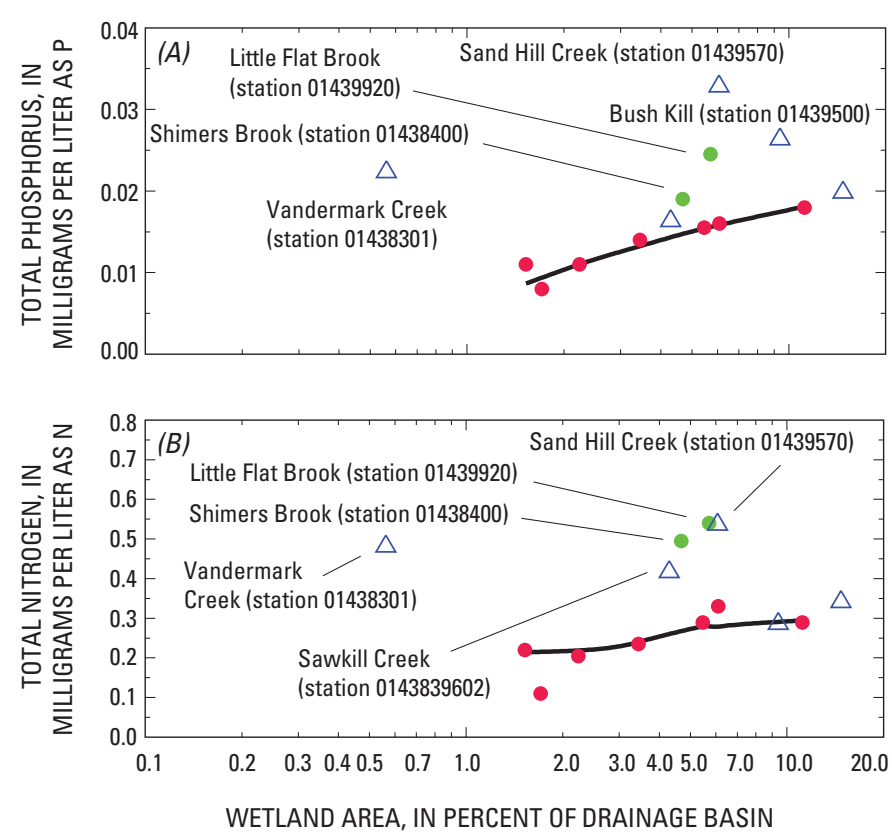

EXPLANATION

LOWESS smoothed line through median concentrations at waterquality monitoring stations with no permitted wastewater facility and agricultural land use is less than 5 percent of the basin area

\section{MEDIAN CONCENTRATION AT A WATER-QUALITY MONITORING STATION}

- Station with no permitted wastewater facility and agricultural land use is greater than or equal to 5 percent of the basin area

- Station with no permitted wastewater facility and agricultural land use is less than 5 percent of the basin area

$\triangle \quad$ Station with permitted wastewater facility

Figure 6. Median concentrations of $(A)$ total phosphorus and $(B)$ total nitrogen at water-quality stations as a function of wetland area and the presence of permitted wastewater facilities in associated drainage basins, for streams in and near the Delaware Water Gap National Recreation Area, Pa. and N.J., 2002-04.

presence of urban land or other land use sometimes associated with large wastewater facilities.

The median concentrations for Vandermark Creek (station 01438301) and Sawkill Creek (station 0143839602) may also be affected by the on-lot septic systems in Milford, Pa. Milford, a borough of about 1,000 residents, is almost entirely served by on-lot septic systems (Lenny Schall, Pennsylvania Department of Environmental Protection, oral commun., 2007). The basins of both streams include parts of this borough.

The median attenuation turbidity in all 14 streams appears to be strongly related to the wetland area in the associated basin. Median values of attenuation turbidity increased with an increase in the area of wetlands in the associated basin (table 6; fig. 7); the level of significance of this relation is $<0.0001$. Given that most of the measurements of attenua- tion turbidity were conducted under base-flow conditions, the values of attenuation turbidity are more likely to represent the true color of the streamflow due to dissolved materials and less likely to represent the particulate material in the water. Therefore, this relation appears to be between the color of the streams and the amount of wetland in the basins.

The correlation between attenuation turbidity and amount of wetlands in the drainage basin likely is due to the greater amount of dissolved organic material in streamflow leaving wetlands than is present in streamflow leaving other types of land use; the color of water in wetlands typically is directly related to the amount of dissolved organic material in the water. Hem (1985) notes that "color in natural water usually results from leaching of organic debris" and that "intensely colored waters occur in many environments where vegetation is plentiful, as in swamps and bogs." Concentrations of dissolved organic carbon (a measure of dissolved organic material) are greatest in surface water in wetland areas compared to that in other types of natural waters (Thurman, 1985).

Relations between color and (or) concentration of dissolved organic carbon in streams and lakes and the percentage of drainage basin composed of wetlands are reported by others. Gergel and others (1999) report concentrations of dissolved organic carbon in lakes and rivers in Wisconsin increased with an increase in the wetlands in the associated drainage basins. Dillon and Molot (1997) report that the concentrations of dissolved organic carbon and the color of streams increased with increasing wetland area in mostly forested basins in Ontario, Canada.

Median values of dissolved chloride concentrations and specific conductance increased with increasing area of agricultural land in the associated basins (table 6). The reasons for these two relations are unknown, but the correlations may be attributed to fertilizer use. The smallest median concentrations of dissolved chloride measured in Vancampens Brook (station 01440100) (fig. 4) likely are due, in part, to the small amount of agricultural land in the basin; this stream drains the basin with the second smallest amount of agricultural land.

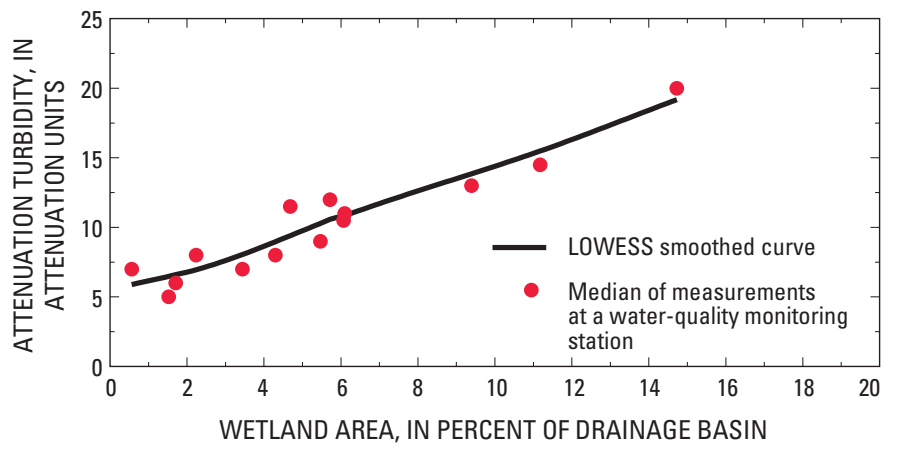

Figure 7. Median values of attenuation turbidity at waterquality monitoring stations as a function of wetland area in the associated drainage basins, for streams in and near the Delaware Water Gap National Recreation Area, Pa. and N.J., 2002-04. 
When all stations are considered, median concentrations of dissolved chloride increased with increasing area of urban land use (table 6), a pattern likely affected by the presence of discharge from wastewater facilities. When only the nine stations in basins without permitted wastewater facilities are considered, however, there is no relation between urban land and median concentrations of dissolved chloride.

Median values of $\mathrm{pH}$, specific conductance, dissolved calcium, and acid-neutralizing capacity in Little Flat Brook (station 01439920), Sand Hill Creek (station 01439570), and Shimers Brook (station 01438400) are the greatest of those from the 14 streams sampled (fig. 4). A comparison of a map of the drainage basins to a geologic map indicates that the basins associated with these three streams are underlain by carbonate rocks. The presence of carbonate rocks in the basins of Little Flat Brook and Shimers Brook in New Jersey was confirmed by an examination of the bedrock geologic map of northern New Jersey (Drake and others, 1996), but corresponding maps of the Sand Hill Creek basin were not readily available. The bedrock geologic map of northern New Jersey (Drake and others, 1996) does indicate that carbonate rocks likely underlie the Sand Hill Creek basin in Pennsylvania, however. Carbonate rocks are, generally, more soluble than most other types of rock; the presence of carbonate rock in a basin tends to raise the values of these water-quality characteristics in the stream draining the basin to levels that probably would not occur if the carbonate rocks were not present in the basin. ANC, a measure of the ability of streamwater to react with and neutralize acid, is a function of the amount of bicarbonate and carbonate in solution (Hem, 1985). Calcium is a major component of carbonate rocks.

\section{Linear Equations Relating Water Quality, Streamflow, and Season}

Linear equations relating values of water-quality characteristics, streamflow, and season (appendix 4) were developed as part of (1) the analyses relating water quality to streamflow and, separately, to season, and (2) detection of changes in water quality over time. An equation was developed if there were a sufficient number of detected values of a water-quality characteristic, if most of the residuals were normally distributed, and if the predicted values of water-quality characteristics equation appeared to match the measured values. The intercept and level of significance of the intercept, coefficients and levels of significance of the coefficients, and the value of scale in each equation are shown in appendix 4.

\section{Variation of Water Quality with Streamflow and Season}

Variations in values of a water-quality characteristic with streamflow and (or) season were examined because, in part, they describe how water quality varies over time. An understanding of how current water quality varies over time is needed in order to determine whether the water quality measured in the future is different from current water quality.

Variations of values of a water-quality characteristic with streamflow and (or) season also provide information on other factors that affect water quality. For instance, a decrease in concentrations of a characteristic with increasing streamflow could indicate that ground-water and (or) point-source discharges are important sources of that characteristic. In contrast, an increase in concentrations of a characteristic with increasing streamflow could indicate that material washed off the land surface during storms is an important source.

Most water-quality characteristics varied with increasing streamflow at most stations (table 7). Nine of the water-quality characteristics increased or decreased with increasing streamflow at nine or more stations.

Concentrations of dissolved orthophosphate phosphorus, dissolved nitrate plus nitrite, and dissolved ammonia decreased with increasing streamflow at more stations than concentrations increased with increasing streamflow. For example, concentrations of dissolved nitrate plus nitrite decreased with increasing streamflow at 9 stations and increased with increasing streamflow at 0 stations. These relations indicate that point-source discharges and (or) groundwater discharge (including septic-system discharge) are probable sources of these nutrients. An example graph showing decreasing concentrations of dissolved nitrate plus nitrite as a function of increasing streamflow is illustrated in figure 8 . The relation between the concentrations and season shown in figure 8 is discussed below.

Concentrations of total phosphorus and total nitrogen were more likely to increase with increasing streamflow than to decrease (table 7). Concentrations of total phosphorus increased at five stations and decreased at one; concentrations of total nitrogen increased at seven stations and decreased at three. These increases could indicate that some of the phosphorus and nitrogen is associated with particulate material, which commonly increases in concentration with increases in streamflow. An example of concentrations of total phosphorus increasing with increasing streamflow is shown in figure 9; an example of concentrations of total nitrogen increasing with increasing streamflow is shown in figure 10.

The three stations at which concentrations of either total phosphorus or total nitrogen decreased with increasing streamflow - Bush Kill (station 01439500), Sawkill Creek (station 0143839602), and Vandermark Creek (station 01438301) - are all in basins with permitted wastewater facilities. The presence of permitted wastewater facilities may explain the decreasing concentrations with increasing streamflow if the permitted facilities discharged large amounts of phosphorus or nitrogen relative to other sources.

Values of attenuation turbidity increased with increasing streamflow at all stations (table 7); one example is given in figure 11. Increasing turbidity with streamflow is common and likely the result of particulate material washing off land surface during storms and the suspension of streambed material; 


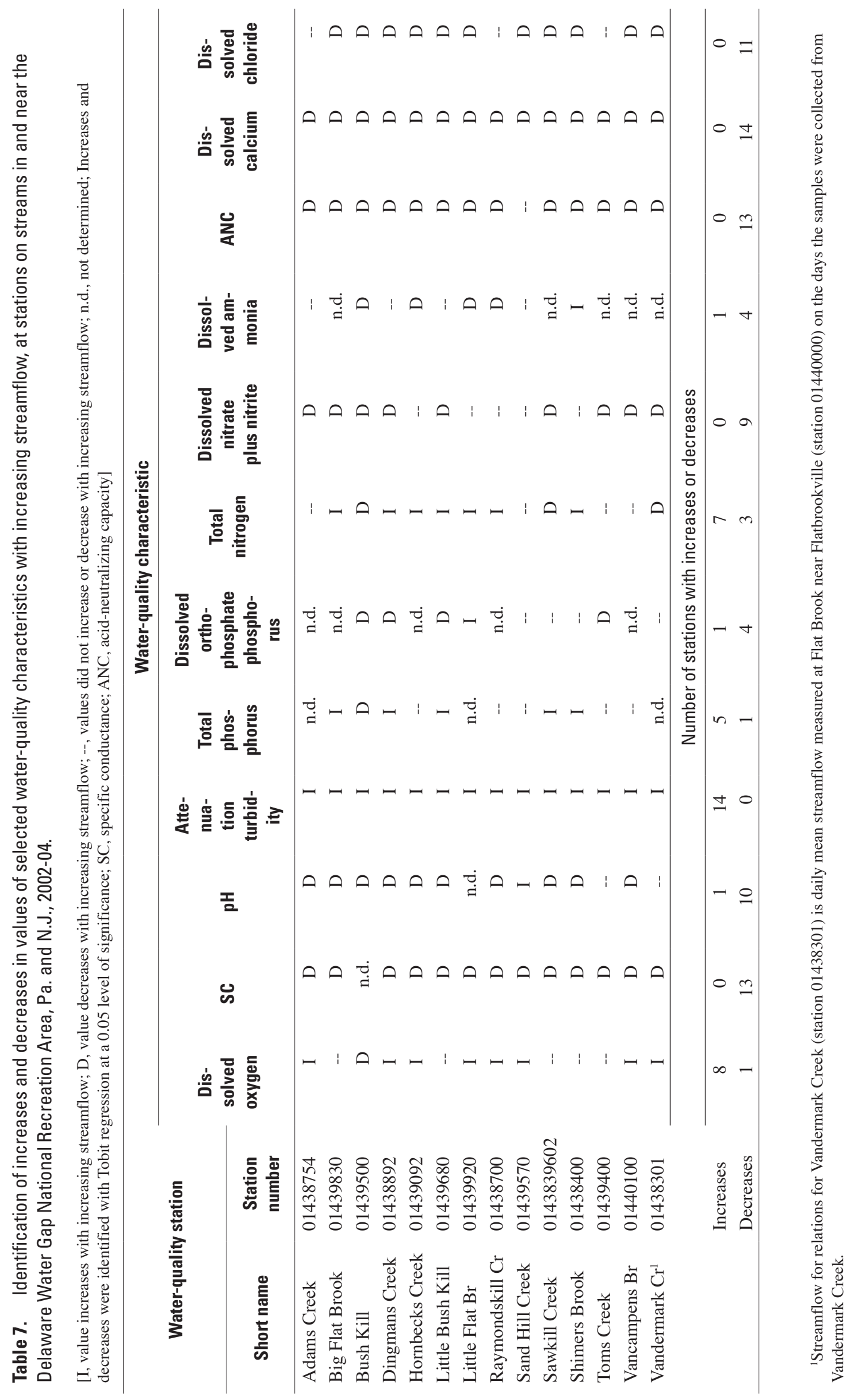



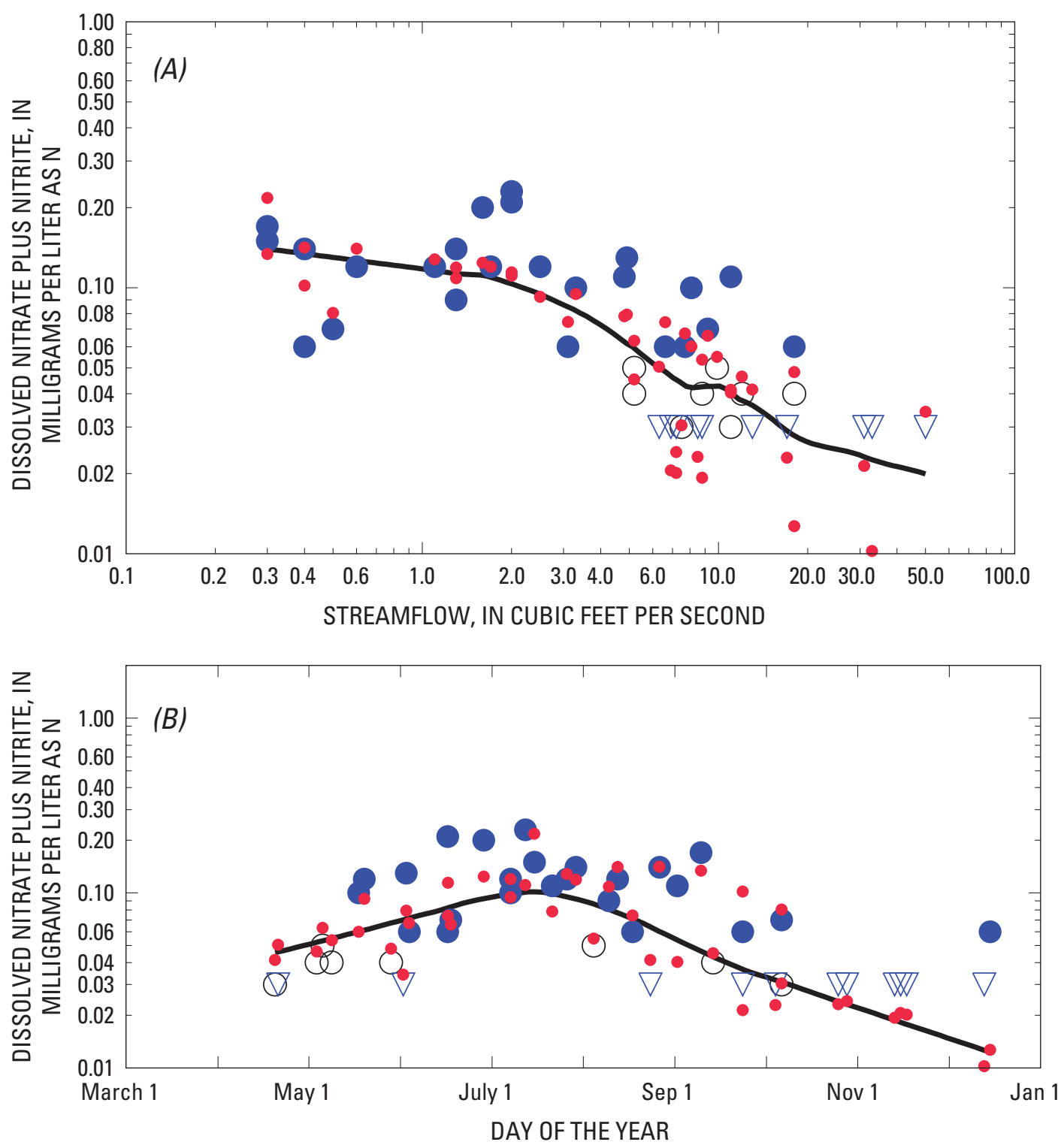

EXPLANATION

LOWESS smoothed curve through
predicted values
Uncensored value
Estimated value
$\nabla$ Nondetect value
- Value predicted with equation

Figure 8. Concentration of dissolved nitrate plus nitrite as a function of $(A)$ streamflow and $(B)$ day of the year at the water-quality monitoring station (01438754) on Adams Creek below Long Meadow Brook near Edgemere, Pa., near the border of the Delaware Water Gap National Recreation Area, Pa. and N.J., 2002-04. 

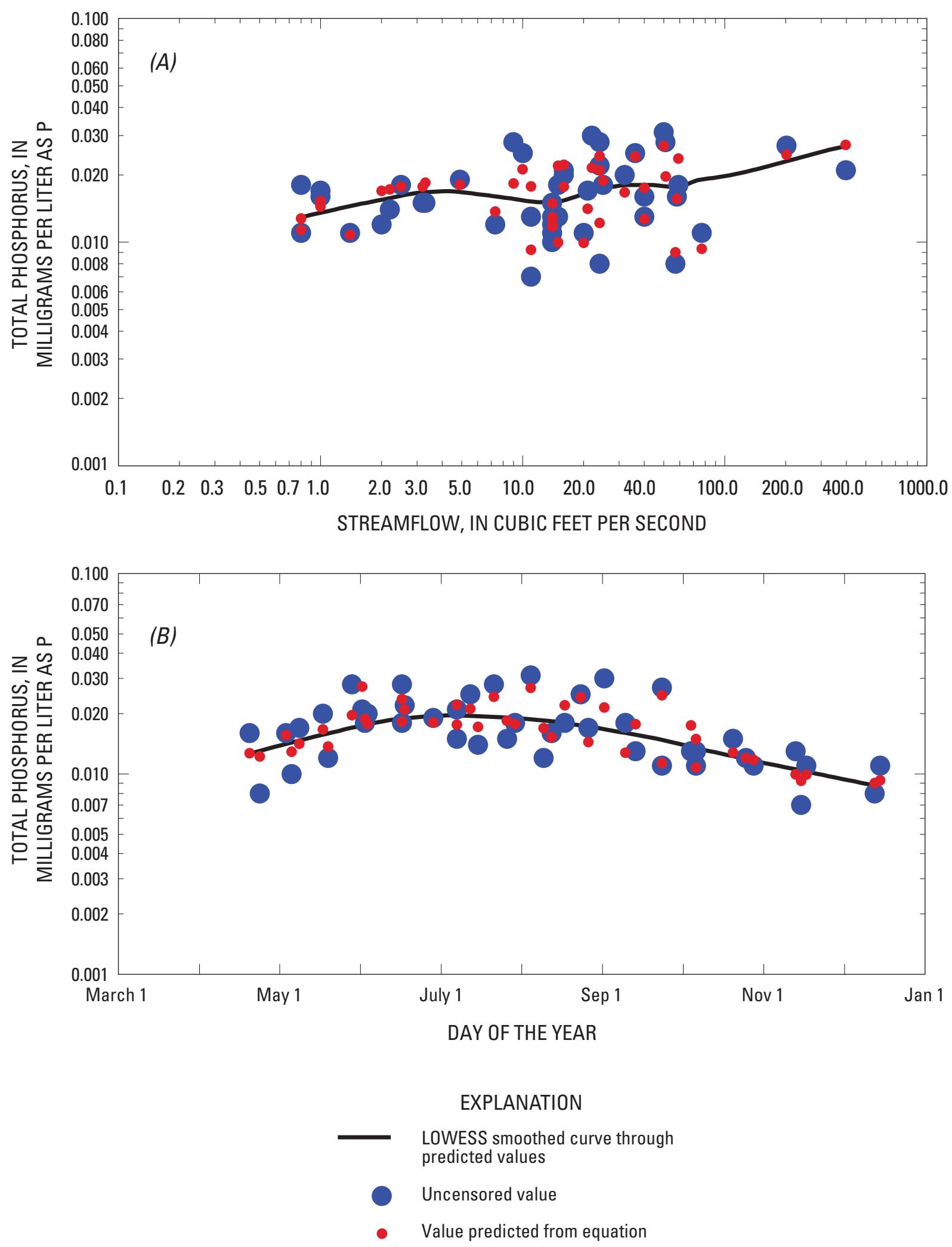

Figure 9. Total phosphorus as a function of $(A)$ streamflow and $(B)$ day of the year at the water-quality monitoring station (01438892) on Dingmans Creek above Dingmans Falls near Dingmans Ferry, Pa., near the border of the Delaware Water Gap National Recreation Area, Pa. and N.J., 2002-04. 

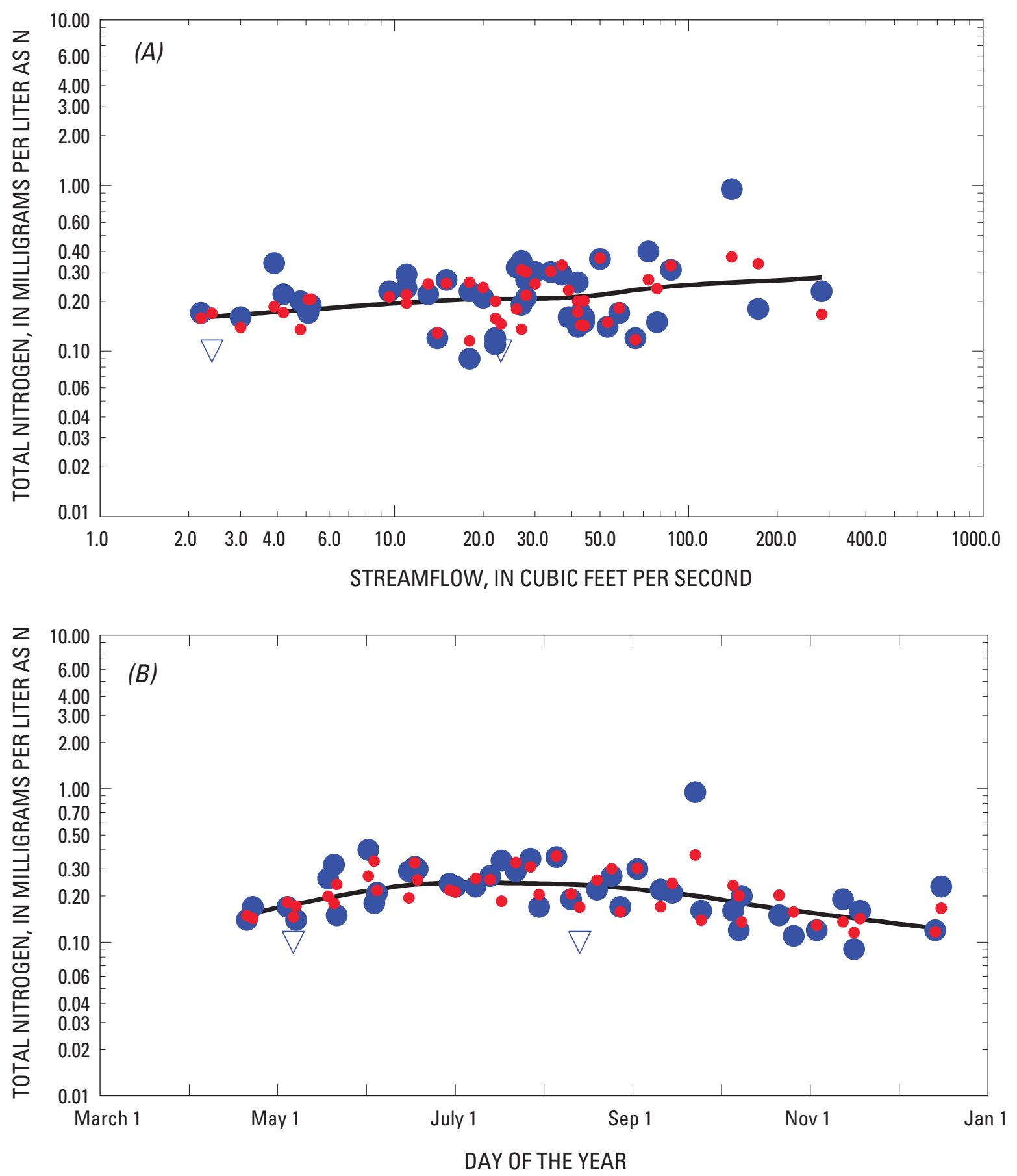

\section{EXPLANATION}

LOWESS smoothed curve through predicted values

Uncensored value

Nondetect value

- Value predicted with equation

Figure 10. Total nitrogen concentration as a function of $(A)$ streamflow and $(B)$ day of the year at the water-quality monitoring station (01439830) on Big Flat Brook at Tuttles Corner, Pa., near the border of the Delaware Water Gap National Recreation Area, Pa. and N.J., 2002-04. 
however, as previously discussed, the values of attenuation turbidity include the effects of true color as well as particles.

Values of acid-neutralizing capacity, dissolved calcium, dissolved chloride, and specific conductance at almost all stations decreased with increasing streamflow (table 7); one example is given in figure 12 . These water-quality characteristics are measurements of major ions, and concentrations of major ions often decrease with increasing streamflow because the concentrations in precipitation are much lower than concentrations in ground water.

Values of $\mathrm{pH}$ decreased with increasing streamflow at 10 stations (table 7); the relation between $\mathrm{pH}$ and streamflow at the station (01439680) on Little Bush Kill at Bushkill, Pa., is shown in figure 13. This pattern is likely the result of the low $\mathrm{pH}$ of the precipitation in this area; during 2002-04, the weighted mean annual field $\mathrm{pH}$ of precipitation in this area ranged from 4 to 5 (National Atmospheric Deposition Program, 2006). As streamflow increases, the streamflow is more likely to have come from surface runoff (which has had little time to react chemically with soil and rock) than from groundwater discharge (which has had more time to react chemically with soil and rock). As a result, the $\mathrm{pH}$ during periods of high streamflow is more likely to be closer to the $\mathrm{pH}$ of precipitation than is the $\mathrm{pH}$ of streamflow during periods of low flow when the streamflow is made up entirely of ground-water and point-source discharges. In contrast, values of $\mathrm{pH}$ at the station (01439570) at Sand Hill Creek at Bushkill, Pa., increased with increasing streamflow; the reasons for this are unclear.

During July-September, dissolved oxygen concentrations increased with increasing streamflow at eight water-quality stations (table 7); as an example, the relation between dissolved oxygen concentration and streamflow at the station

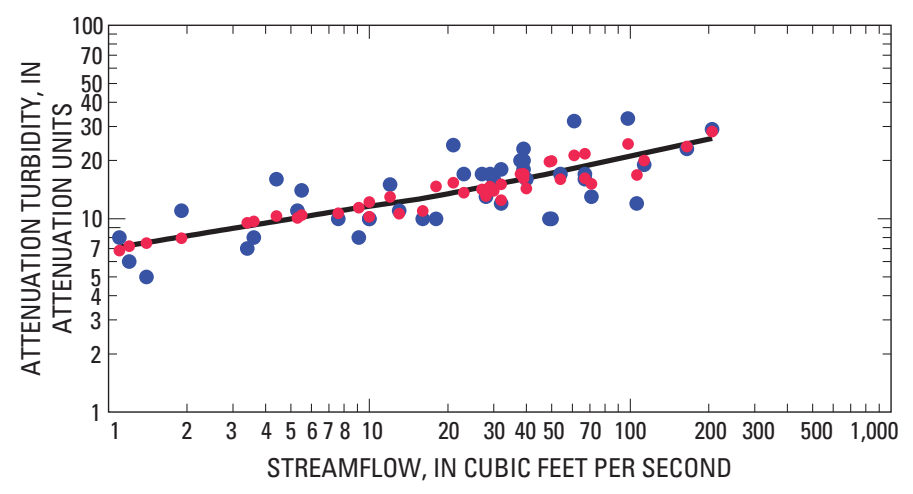

EXPLANATION

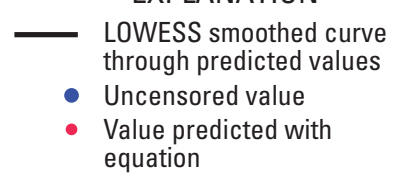

Figure 11. Attenuation turbidity as a function of streamflow at the water-quality monitoring station (01438700) on the Raymondskill Creek near Milford, Pa., near the border of the Delaware Water Gap National Recreation Area, Pa. and N.J., 2002-04.
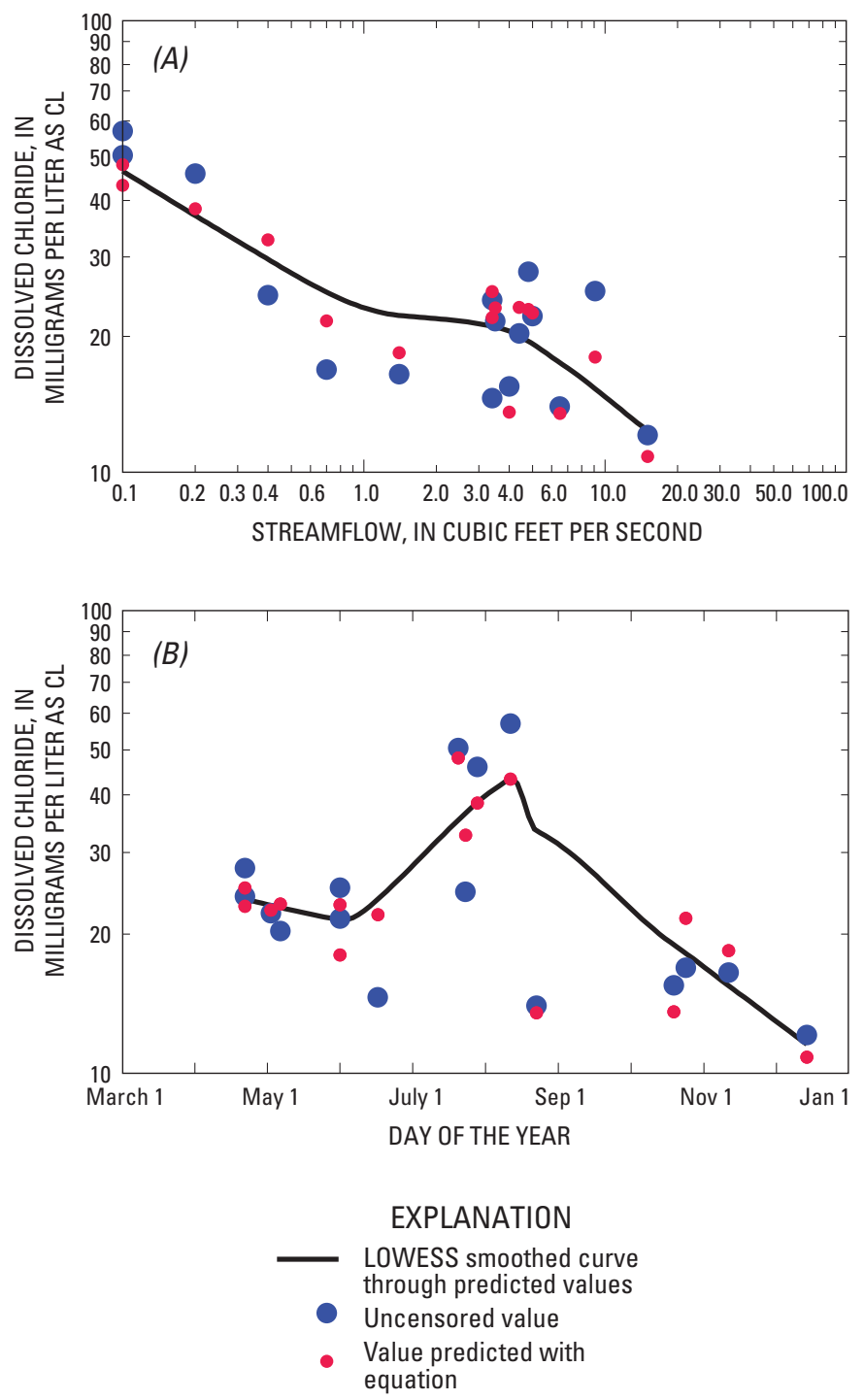

Figure 12. Dissolved chloride as a function of $(A)$ streamflow and $(B)$ day of the year at the water-quality monitoring station (01439570) on the Sand Hill Creek at Bushkill, Pa., near the border of the Delaware Water Gap National Recreation Area, Pa. and N.J., 2002-04.

(01438700) on Raymondskill Creek near Milford, Pa., is shown in figure 14. In streams, there are processes adding oxygen (such as aeration and photosynthesis) and processes which are removing oxygen (such as benthic oxygen demand). These relations indicate that, at higher flows, the rate at which processes remove oxygen from the stream appears to be less than the rate at which processes add oxygen; whereas, at lower flows, the rate at which processes remove oxygen appears to exceed the rate at which processes add oxygen. Low dissolved oxygen concentrations in streamflow leaving wetlands may also be affecting the concentrations in streams during periods of low flow. In contrast, dissolved oxygen concentrations at the station (01439500) on Bush Kill near Shoemakers, Pa., 


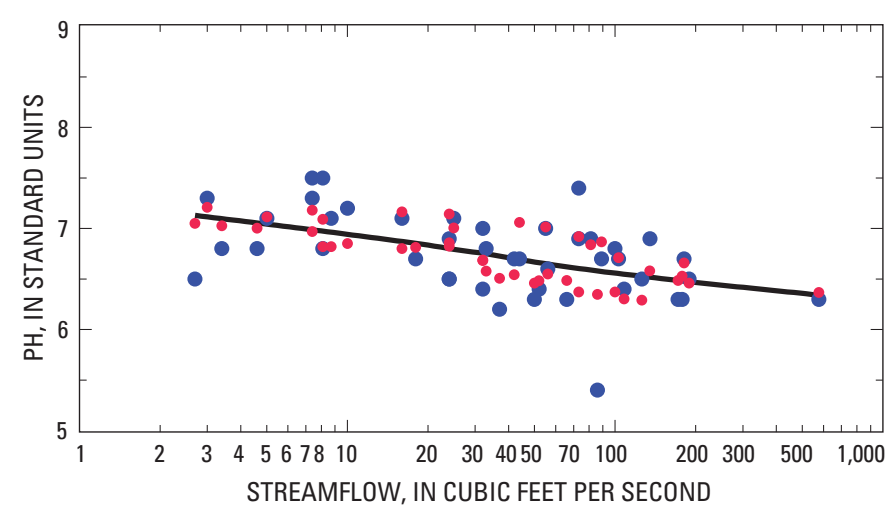

EXPLANATION

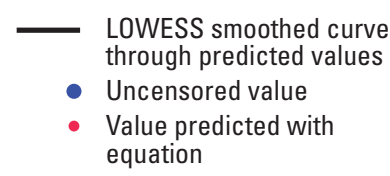

Figure 13. Values of $\mathrm{pH}$ as a function of streamflow at the waterquality monitoring station (01439680) on the Little Bush Kill at Bushkill, Pa., near the border of the Delaware Water Gap National Recreation Area, Pa. and N.J.,2002-04.

decreased with increasing streamflow, possibly as a result of supersaturation from photosynthesis at low streamflow.

Results of tests to determine whether values of a waterquality characteristic at a station varied with season are shown in table 8 . For this analysis, season is represented by the Julian day of the year.

Due to the method of identification of seasonality, the variation of a water-quality characteristic with season is the result of the seasonal variation in conditions or processes other than streamflow. These other conditions or processes include (1) the loads of that water-quality characteristic, that are discharged to the stream, and (or) (2) instream biological, chemical, and (or) physical processes that affect water quality. The results of this analysis only identified whether or not values of water-quality characteristics varied with season; the analysis did not determine the seasons during which the values were greatest or smallest. For a given water-quality characteristic, seasonal relations at different stations may indicate different seasonal patterns at different stations. The relation between a water-quality characteristic and season does not necessarily represent conditions during January-March because no waterquality characteristics were measured during these months.

For 10 of the 11 water-quality characteristics analyzed, values varied seasonally at 7 or more stations (table 8 ). Values of dissolved oxygen were not tested for seasonality because only the measurements made during July-September were considered in this analysis.

Concentrations of nitrogen and phosphorus species varied with season at almost all stations for which calculations were made (table 8). Concentrations during the summer (JulySeptember) often exceeded concentrations during the spring (April-June) and fall (October-December). Examples of this
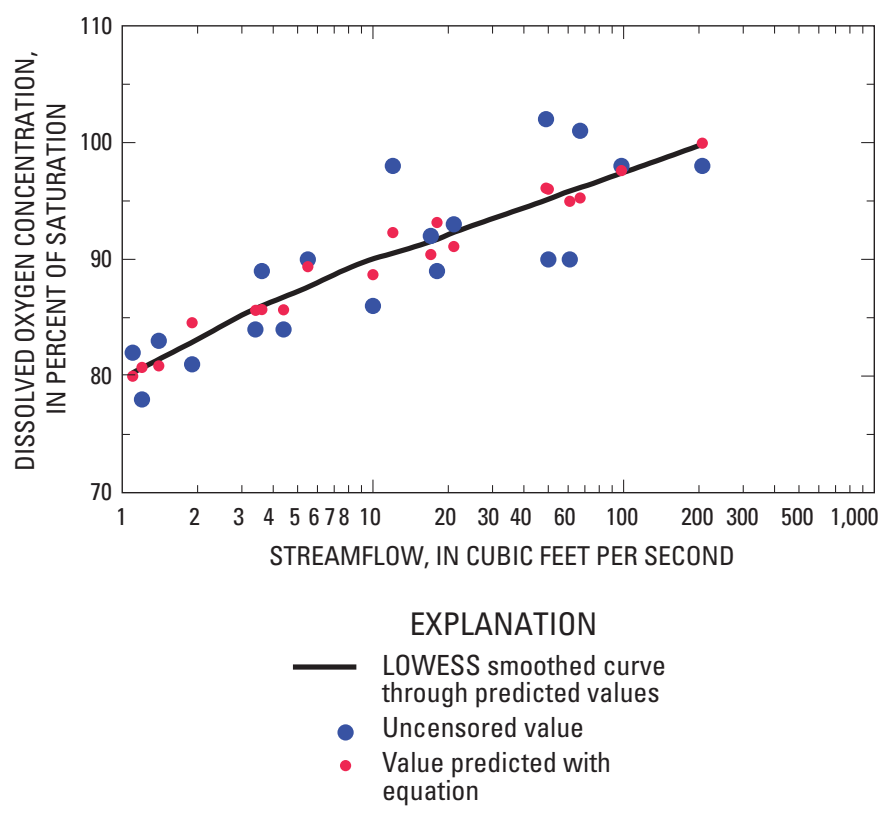

Figure 14. Dissolved oxygen concentration as a function of streamflow at the water-quality monitoring station (01438700) on the Raymondskill Creek near Milford, Pa., near the border of the Delaware Water Gap National Recreation Area, Pa. and N.J., JulySeptember, 2002-04.

seasonal variation are shown in figures 8 to 10 . As one example, concentrations of total nitrogen in Big Flat Brook (station 01439830) are between 0.1 and 0.2 milligrams per liter as $\mathrm{N}$ in the spring and fall, but increase to between 0.2 and 0.3 milligrams per liter as $\mathrm{N}$ during the summer. This pattern may indicate that sources of phosphorus and nitrogen were greater during summer than during spring or fall. This pattern would be consistent with the greater discharges from wastewatertreatment plants and septic systems in the study area during the summer that results from increased summer population. Another possibility is that this pattern is due to increased wash off of fertilizers from agricultural lands, although the greatest loads from fertilizer washing off agricultural land might occur during rainstorms immediately following a major application in the spring.

The concentration of dissolved chloride varied seasonally at nine stations (table 8). At some stations, the seasonal variation in concentrations of dissolved chloride followed the pattern as shown by nitrogen and phosphorus concentrations; concentrations during July-September were greater than those during other months. For example, the greatest concentrations of dissolved chloride at the Sand Hill Creek at Bushkill, Pa., station (01439570) were measured during July-September (fig. 12). This pattern may indicate that discharge from wastewatertreatment facilities (including septic systems) are important sources of chloride in some basins. 

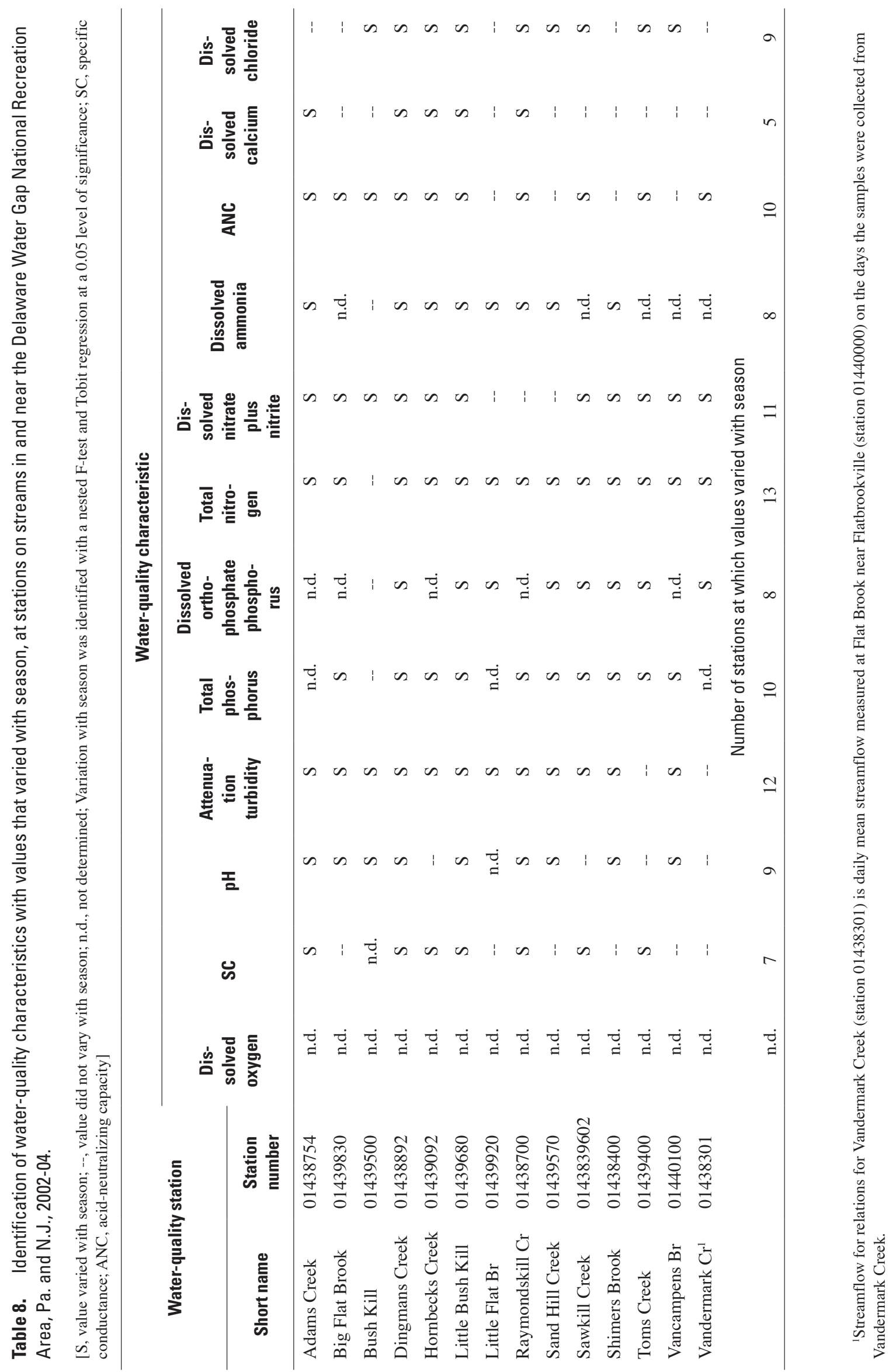


\section{Detection of Future Changes in Water Quality}

In order for either method described in this report to accurately detect future changes in water quality, the techniques of field measurement, sample collection, and analysis in the future have to be the same as those used to measure water quality during 2002-04 (previously discussed). Otherwise, differences between current and future water quality identified by these or other methods could simply be an artifact of the differences in techniques.

Also, streamflow measurements at the times of the future sample collection will have to be available for at each station in order for the variation of water quality with streamflow to be considered in the analysis. For 13 of the stations, this means that instantaneous streamflow will need to be measured or estimated at the times of sample collection. For days on which samples are collected at the station (01438301) on Vandermark Creek at 4th Street at Milford, Pa., the record of daily streamflow for the station (01440000) Flat Brook near Flatbrookville, N.J., will need to be available.

Either of the two methods mentioned in this report-the seasonal rank sum test or the analysis of intercepts - can be used to identify future changes in water quality. The seasonal rank sum test can be used for values of any water-quality characteristic at any of the stations, whether or not equations could be developed that relate both current values and future values of the water-quality characteristic to streamflow and season. The analysis of intercepts can be used only if both equations could be developed for values of a water-quality characteristic at a station. Once an equation relating current values of a specified water-quality characteristic at a station to streamflow and season is developed, this method allows an estimate of the minimum change in current values of the water-quality characteristic at a station that can be detected.

The minimum detectable changes between current and future water-quality values are given in table 9 for those water-quality characteristics with equations relating current values of the characteristic at a station to streamflow and season (Appendix 4). To calculate these values, 10 measurements of future water quality and a 0.05 level of significance were assumed.

The minimum detectable changes in table 9 are expressed as the percentage of the intercept for the equations with current values of water quality. Each intercept represents an estimate of the current value of a specified water-quality characteristic at a specified station when streamflow was $1 \mathrm{ft}^{3} / \mathrm{s}$ during a season in which the variation in water quality due to season was minimal. If the left-hand side of the equation is the logarithm of the water quality, the intercept represents the logarithm of the value of the water-quality characteristic under these conditions.

The minimum detectable changes varied among waterquality characteristics (table 9). For the water-quality characteristics composed of or related to major ions $(\mathrm{pH}$, specific conductance, dissolved calcium, acid-neutralizing capacity, or dissolved chloride) minimum detectable changes were 1 to 9 percent of intercepts. For attenuation turbidity, total phosphorus, and total nitrogen, the minimum detectable changes were 3 to 12 percent; and for dissolved orthophosphate phosphorus, dissolved nitrate plus nitrite, and dissolved ammonia, 6 to 30 percent.

Examination of equation 15 indicates that the magnitudes of minimum detectable changes (table 9) are related to the number of current values of water-quality characteristics and to the value of scale (goodness of fit) of the linear relations, which are presented in Appendix 4. The minimum detectable change decreases with an increase in the number of values of a current water-quality characteristic and increases with an increase in the value of scale (a measure of the error in the fit of the equation to the measured values).

When considering the changes (between current and future water-quality values) that are detectable using this method, it is assumed that the relations between future water quality and streamflow or season are similar to those between current water quality and streamflow, and season. Given the uncertainty of the relations in the future, the actual detectable changes are likely to be larger than those changes calculated in this report.

Assuming that future methods used to measure waterquality characteristics will be similar to the methods used to measure water-quality characteristics during 2002-04, any detectable changes between current and future water-quality values then can be attributed to either changes in basin characteristics or, possibly, to changes in climate. Basin characteristics that can change and result in changes in water quality over time include land use, wastewater-discharge facilities, and any human activity that alters the streamflow.

\section{Summary and Conclusions}

Water samples were collected at stations on 14 streams within or entering the Delaware Water Gap National Recreation Area, Pa., and N.J., during 2002-04 in order to define water quality and provide a baseline from which to detect changes in water quality over time. Measurements of physical characteristics and analyses of samples for plant nutrients and major ions were made from April through December of each year, mostly under base-flow conditions. Summary statistics were generated for dissolved oxygen, specific conductance, $\mathrm{pH}$, attenuation turbidity, total phosphorus, dissolved orthophosphate phosphorus, total nitrogen, dissolved nitrate plus nitrite, dissolved ammonia, acid-neutralizing capacity, dissolved chloride, and dissolved calcium. Boxplots were created for all water-quality characteristics except dissolved orthophosphate phosphorus and dissolved ammonia.

For a given water-quality characteristic, median values commonly varied among the 14 water-quality monitoring stations. For example, the median concentration of total phosphorus at the station on Sand Hill Creek (0.033 milligrams per liter as $\mathrm{P}$ ) was four times the corresponding median concentra- 


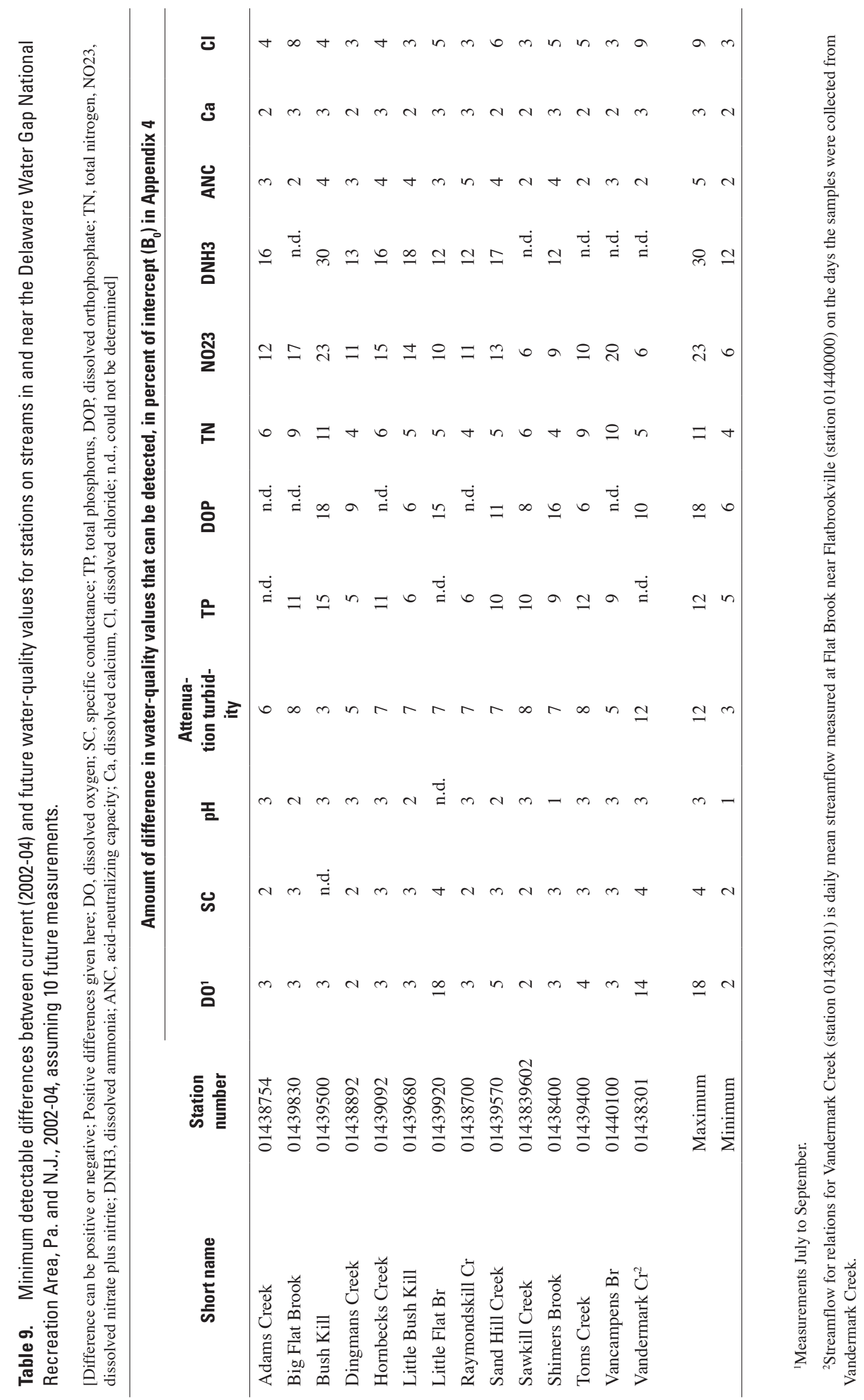


tion at the station on Vancampens Brook (0.008 milligrams per liter as P).

Median values of water-quality characteristics at all 14 stations were correlated with land-use characteristics of the drainage basins to identify land uses that appear to affect water quality. Results indicate that median concentrations of total nitrogen and dissolved nitrate plus nitrite increased with an increase in the area of agricultural land in the associated basin (levels of significance are 0.01 and 0.027 , respectively), but not with increases in the area of either high-intensity or low-intensity urban land. No relations were identified between median concentrations of other phosphorus and nitrogen species and the area of either agricultural, high-intensity urban, or low-intensity urban land.

Correlations between median values of phosphorus and nitrogen species and land use were repeated with only the nine stations without permitted wastewater facilities in order to reduce any influence of large wastewater discharges on the relations. Results indicate that agricultural practices could be an important factor affecting the concentrations of both total nitrogen and total phosphorus in these streams. Median concentrations of both total phosphorus and total nitrogen increased with an increase in the area of agricultural land in the drainage basins; the levels of significance are 0.01 for total phosphorus and 0.01 for total nitrogen.

Results of correlations may also indicate that the areas of wetlands in a basin could be a factor affecting the concentrations of total nitrogen and total phosphorus in these streams. When only the seven stations without permitted wastewater facilities and with less than 5 percent of the basin composed of agricultural land were considered, median concentrations of total phosphorus and total nitrogen increased with an increase in the amount of wetland area; the levels of significance are 0.003 for total phosphorus and 0.03 for total nitrogen.

The presence of a permitted wastewater facility that discharges into the drainage basin may also affect the concentrations of total phosphorus and total nitrogen in streamflow leaving some of the five basins with such facilities. When plotted as a function of wetland area, median concentrations of total phosphorus and (or) total nitrogen at four of the five stations with wastewater facilities in their drainage basins (Vandermark Creek, station 01438301; Sand Hill Creek, station, 01439570; Sawkill Creek, station 0143839602; and Bush Kill, station 01439500) were noticeably greater than the median concentrations at stations with no permitted facilities and with less than 5 percent agricultural land in the basin. The high median concentrations of nutrients at stations with permitted wastewater discharge could be due to the effects of wastewater discharged directly to the streams, the result of ground water leaving septic systems and discharging to the stream, or reflect the presence of urban land or other land use sometimes associated with large wastewater facilities.

The median attenuation turbidity in all 14 streams appears to be strongly related to the wetland area in the associated basin. Median values of attenuation turbidity increased with an increase in the area of wetlands in the associated basin; the level of significance of this relation is $<0.0001$. Given that most of the measurements of attenuation turbidity were conducted under base-flow conditions, the values of attenuation turbidity are more likely to represent the true color of the streamflow due to dissolved materials and less likely to represent the particulate material in the water.

Median values of $\mathrm{pH}$, specific conductance, dissolved calcium, and acid-neutralizing capacity (ANC) in Little Flat Brook (station 01439920), Sand Hill Creek (station 01439570), and Shimers Brook (station 01438400) are the greatest of those in the 14 streams sampled. A comparison of a map of the drainage basins to a geologic map indicates that the basins associated with these three streams are underlain or are likely underlain by carbonate rocks. The presence of carbonate rocks in the three basins would account for the greater values of $\mathrm{pH}$, specific conductance, ANC, and dissolved calcium in these three streams than in the other streams

Linear equations between values of each water-quality characteristic, streamflow, and season at each station were developed from Tobit regression. Whether values of water quality changed with increasing streamflow and (or) with changes in season were determined partly from an examination of these equations.

Concentrations of dissolved orthophosphate phosphorus, dissolved nitrate plus nitrite, dissolved ammonia, and major ions decreased with increasing streamflow at more waterquality stations than concentrations increased with increasing streamflow. For example, concentrations of dissolved nitrate plus nitrite decreased with increasing streamflow at nine stations and increased with increasing streamflow at no stations. These relations likely indicate that point-source discharges and (or) ground-water discharge (including septic-system discharge) are important sources of these constituents.

Concentrations of total phosphorus, total nitrogen, and attenuation turbidity increased with increasing streamflow at more stations than concentrations decreased with increasing streamflow. Concentrations of total phosphorus increased with increasing streamflow at five stations and decreased with increasing streamflow at one station; the corresponding values for total nitrogen increased at seven stations and decreased at three. This pattern occurred because values of these nutrients are affected by particulate material in the streams, and particulate material often increases with increasing streamflow.

Most water-quality characteristics varied with season at most stations due to reasons other than the seasonal variation in streamflow. For 10 of the 11 water-quality characteristics analyzed, changes with season were identified for 7 or more stations. Due to the method of identification of seasonality, the variation of a water-quality characteristic with season is the result of the seasonal variation in conditions or processes other than streamflow.

Concentrations of nitrogen and phosphorus species varied with season for most water-quality monitoring stations; concentrations of nitrogen and phosphorus species varied with season at 10 and 13 stations, respectively. Concentrations during the summer (July-September) often exceeded con- 
centrations during the spring (April-June) and fall (OctoberDecember). As one example, concentrations of total nitrogen in Big Flat Brook (station 01439830) are between 0.1 and 0.2 milligrams per liter as $\mathrm{N}$ in the spring and fall but increase to between 0.2 and 0.3 milligrams per liter as $\mathrm{N}$ during the summer. This pattern may indicate that sources during the summer were greater than sources during spring or fall, which would be consistent with the greater discharges from wastewatertreatment plants and septic systems during the summer that result from increased summer population.

A method to detect changes in future water quality was described. The method is based on the linear equations developed between values of water-quality characteristics, streamflow, and season. For each water-quality characteristic at each station, the equation with current water-quality values is compared to the equation which will be determined with future water quality. Changes in future water quality are identified by testing for differences in the intercepts of the two equations. The intercept represents an estimate of the current value of a water-quality characteristic measured at a station (1) with a streamflow of 1 cubic foot per second and (2) during a season in which the seasonal variation of water quality is minimal.

The method to detect changes in future water quality was selected, in part, because it allows for an estimate of the minimum change in current water quality that can be detected. Assuming 10 measurements will be made in the future, the minimum detectable changes in total phosphorus or total nitrogen at any of the stations are 4 to 12 percent of the intercepts in equations for current water quality.

These methods can be used to generate an overall assessment of the current and potential effects of land development on water quality in streams entering the park. On the basis of data collected during the study, managers can develop numeric regulatory standards for the water quality of streams and a cost effective strategy for future monitoring. Use of standard protocols will allow for comparison of the results from this study with results from studies in other regions of the country. Information on efficient monitoring designs and the effects of residential development are relevant to most of the parks which have rivers or streams flowing into them from outside park boundaries.

\section{References Cited}

American Public Health Association, 1998, Standard methods for the examination of water and wastewater $\left(20^{\text {th }} \mathrm{ed}\right.$.): Washington, D.C., p. 1-1 through 10-159 plus plates and index.

DeLuca, M.J., Heckathorn, H.A., Lewis, J.M., Gray, B.J., Melvin, E.L., Riskin, M.L., and Liu, N.A., 2005, Water resources data for New Jersey-water year 2004, volume 3, Water-quality data: U.S Geological Survey Water-Data Report NJ-05-3, 680 p.
DeLuca, M.J., Heckathorn, H.A., Lewis, J.M., Gray, B.J., and Feinson, L.S., 2006, Water resources data for New Jerseywater year 2005, volume 3, Water-quality data: U.S Geological Survey Water-Data Report NJ-04-3, 568 p.

Dillon, P.J., and Molot, L.A., 1997, Effect of landscape form on export of dissolved organic carbon, iron, and phosphorus from forested stream catchments: Water Resources Research, v. 33, n. 11, p. 2591-2600.

Drake, Jr., A.A., Volkert, R.A., Monteverde, D.H., Herman, G.C., Houghton, H.F., Parker, R.A., and Dalton, R.F., 1996, Bedrock Geologic Map of Northern New Jersey: U.S. Geological Survey Miscellaneous Investigations Series, Map I-2540-A, 2 sheets.

Eastern Brook Trout Joint Venture, 2006, Eastern Brook Trout, Status and Trends: Trout Unlimited, 30 p., accessed on June 20, 2007 at http://www.easternbrooktrout.org/statusta.html

Federal Interagency Sedimentation Project, undated, U.S. DH-81 sampler, accessed on August 16, 2005, at http://fisp. wes.army.mil/Catalog_Page_US_DH-81_Sampler.htm

Fischer, J.M., Riva-Murray, Karen, Hickman, R.E., Chichester, D.C., Brightbill, R.A., Romanok, K.M., and Bilger, M.D., 2004, Water quality in the Delaware River Basin, Pennsylvania, New Jersey, New York, and Delaware, 1998-2001: U.S. Geological Survey Circular 1227, 38 p.

Fishman, M.J., ed., 1993, Methods of analysis by the U.S. Geological Survey National Water Quality LaboratoryDetermination of inorganic and organic constituents in water and fluvial sediments: U.S. Geological Survey OpenFile Report 93-125, 217 p.

Fishman, M.J., and Friedman, L.C., 1989, Methods for determination of inorganic substances in water and fluvial sediments: U.S. Geological Survey Techniques of WaterResources Investigations, book 5, chap. A1, 545 p.

Gergel, S.E., Turner, M.G., and Kratz, T.K., 1999, Dissolved organic carbon as indicator of the scale of watershed influence on lakes and rivers: Ecological Applications, v. 9, no. 4, p 1377-1390.

Heisig, Paul M., 2000, Effects of residential and agricultural land uses on the chemical quality of baseflow of small streams in the Croton watershed, southeastern New York: U.S. Geological Survey Water-Resources Investigations Report 99-4173, 15 p.

Helsel, D.R., 2005, Nondetects and data analysis, statistics for censored environmental data: Hoboken, New Jersey, John Wiley \& Sons, Inc., 250 p.

Helsel, D.R., and Hirsch, R.M., 1992, Statistical methods in water resources: New York, Elsevier Science Publishing Company, Inc., 522 p. 
Hem, John D., 1985, Study and interpretation of the chemical characteristics of natural water: U.S. Geological Survey Water-Supply Paper 2254, 263 p., 3 pl.

Hirsch, R.M., 1982, A comparison of four streamflow record extension techniques: Water Resources Research, v. 18, no. 4, p. 1081-1088.

Judge, G.G., Griffiths, W.E., Hill, R.C., and Lee, T.-C., 1980, The theory and practice of econometrics: New York, John Wiley and Sons, $793 \mathrm{p}$.

LaMotte Company, 1997, LaMotte Smart Colorimeter Operators Manual: Chestertown, Maryland, 50 p., accessed on February 22, 2007 at http://www.lamotte.com/pages/common/pdf/instruct/1911manu.pdf

Lister, A., Riemann, R., Lister, T., and McWilliams, W., 2005, Northeastern regional forest fragmentation assessment - Rationale, methods and comparisons with other studies, in Proceedings of the Fifth Annual Forest Inventory and Analysis Symposium, 2003 November 18-20, New Orleans, Louisiana: Washington, DC, U.S. Department of Agriculture Forest Service, General Technical Report WO-69, $222 \mathrm{p}$.

Mathey, Sharon B., ed., 1998, National Water Information System (NWIS): U.S. Geological Survey Fact Sheet FS-027-98, accessed August 16, 2005, at http://water.usgs. gov/pubs/fs/FS-027-98/

Mitsch, W.J., and Gosselink, J.G., 1986, Wetlands: New York, Van Nostrand Reinhold, 537 p.

National Atmospheric Deposition Program (NRSP-3), 2006, Isopleth Maps: NADP Program Office, Illinois State Water Survey, accessed June 9, 2006, at http://nadp.sws.uiuc.edu/ isopleths/annualmaps.asp

National Park Service, 2006, Delaware Water Gap National Recreation Area and Middle Delaware National Scenic River - Water quality, accessed June 20, 2007, at http:// www.nps.gov/dewa/naturescience/water-quality.htm

Oblinger-Childress, C.J., Foreman, W.T., Connor, B.F., and Maloney, T.J., 1999, New reporting procedures based on long-term method detection levels and some considerations for interpretation of water-quality data provided by the U.S. Geological Survey National Water Quality Laboratory: U.S. Geological Survey Open-File Report 99-193, 19 p.

Patton, C.J., and Kryskalla, J.R., 2003, Methods of analysis by the U.S. Geological Survey National Water Quality Laboratory-Evaluation of alkaline persulfate digestion as an alternative to Kjeldahl digestion for determination of total and dissolved nitrogen and phosphorus in water: U.S. Geological Survey Water-Resources Investigations Report 03-4174, 33 p.
Patton, C.J., and Truitt, E.P., 2000, Methods of analysis by the U.S. Geological Survey National Water Quality Laboratory-Determination of ammonium plus organic nitrogen by a Kjeldahl digestion method and an automated photometric finish that includes digest cleanup by gas diffusion: U.S. Geological Survey Open-File Report 00-170, 31 p.

Rantz, S. E., and others, 1982, Measurement and Computation of Streamflow, volumes 1 and 2: U.S. Geological Survey Water-Supply Paper 2175, $631 \mathrm{p}$.

SAS Institute, Inc., 1999a, The Corr Procedure: Cary, N.C., SAS Procedures Guide, Version 8, p. 273-312.

SAS Institute, Inc., 1999b, The Lifereg Procedure: Cary, N.C., SAS/STAT User's Guide, Version 8, p. 1761-1796.

Shelton, L. R., 1994, Field guide for collecting and processing stream-water samples for the National Water-Quality Assessment Program: U.S. Geological Survey Open-File Report 94-455, $42 \mathrm{p}$.

Thurman, E.M., 1985, Organic chemistry of natural waters: Boston, Mass., Martinus Nijhoff/Dr W. Junk Publishers, $497 \mathrm{p}$.

U.S. Census Bureau, 2006a, State and County QuickFacts, accessed on July 6, 2006, at http://quickfacts.census.gov/ qfd/index.html

U.S. Census Bureau, 2006b, TIGER, TIGER/Line, and TIGER-related products, accessed on July 13, 2006, at http://www.census.gov/geo/www/tiger/index.html

U.S. Geological Survey, 1999, The quality of our Nation's waters - nutrients and pesticides: U.S. Geological Survey Circular 1225, $82 \mathrm{p}$.

U.S. Geological Survey, 2006, National Land Cover Data: Sioux Falls, South Dakota, USGS Land Cover Institute, accessed July 11, 2006, at http://landcover.usgs.gov/

Zaugg, S.D., Smith, S.G., Schroeder, M.P., Barber, L.B., and Burkhardt, M.R., 2002, Methods of analysis by the U.S. Geological Survey National Water Quality Laboratory-Determination of wastewater compounds by polystyrenedivinylbenzene solid-phase extraction and capillarycolumn gas chromatography/mass spectrometry: U.S. Geological Survey Water-Resources Investigations Report 01-4186, $37 \mathrm{p}$. 


\section{Appendix 1. Methods used to determine flow at stations on streams in and near the Delaware Water Gap National Recreation Area, Pa. and N.J., at times of water-quality-sample collection, 2002-04}

Values of streamflow were measured or estimated at the times of sampling at 13 of the 14 stream stations (table 1-1). Streamflow was not determined for samples collected at the water-quality monitoring station (01438301) on Vandermark Creek at 4th Street at Milford, Pa., because, on an initial survey, field personnel could not find a good spot to measure streamflow.

Three methods were used to measure most values of streamflow at the 13 stations (table 1-1). All methods are based on discharge measurements made at the stations using the methods described in Rantz and others (1982). At four stations, most values of streamflow were set equal to the streamflow measured by USGS personnel on the days the samples were collected. At the station on the Bush Kill at Shoemakers, Pa. (No. 01439500), stage (the elevation of the streamwater level above a datum) is continuously measured by the USGS, and continuous values of streamflow were calculated from the rating curve (the relation between stage and streamflow) for this station. Values of streamflow at the time of sample collection were taken from the record of streamflow.

At the remaining nine stations, values of streamflow for most samples were based on measurements of stage at the time of sample collection and from a rating curve for the individual station developed with streamflow measurements made during 2002-04. Rating curves for these stations were retrieved from the records of the USGS; an example of one rating curve is shown in figure 1-1.

For some samples, streamflow could not be determined by use of the methods described above. For these samples, streamflow was estimated using a MOVE1 relation (Hirsch, 1982 ) and the record of daily streamflow at 01440000 Flat Brook near Flatbrookville, NJ (fig. 1); an example of one relation is given in figure 1-2. For each station, the MOVE1 curve describes the relation between the measurements of streamflow at the station and the daily streamflow at Flat Brook (01440000) on the days of sample collection. Values of streamflow determined in this way were considered to be "estimated" values and given an "E" remark code. 
Table 1-1. Method used to determine streamflow at the time of collection of most water samples at stations on streams in and near the Delaware Water Gap National Recreation Area, Pa. and N.J., 2002-04.

[Br, Brook; Cr, Creek; --, streamflow not determined]

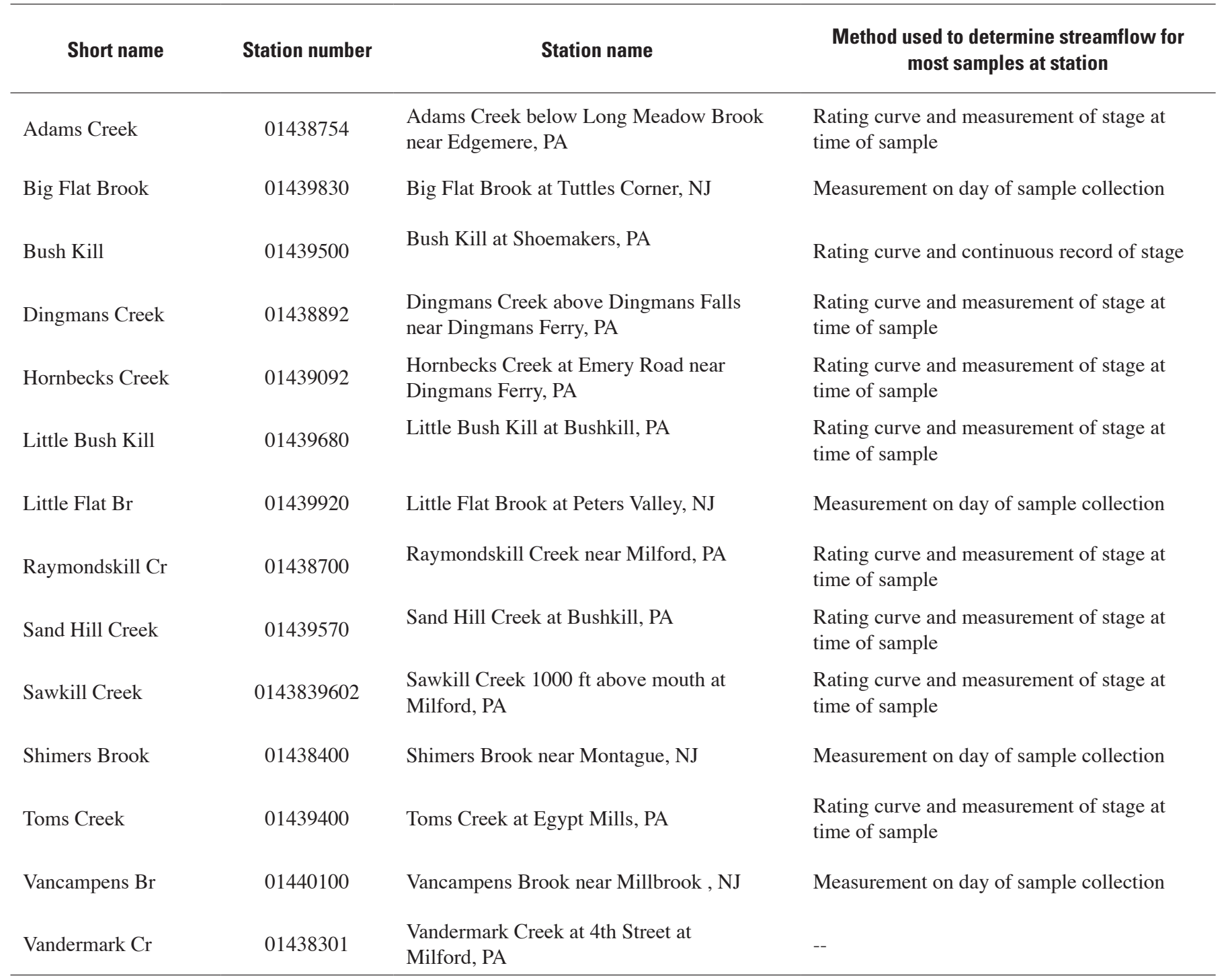




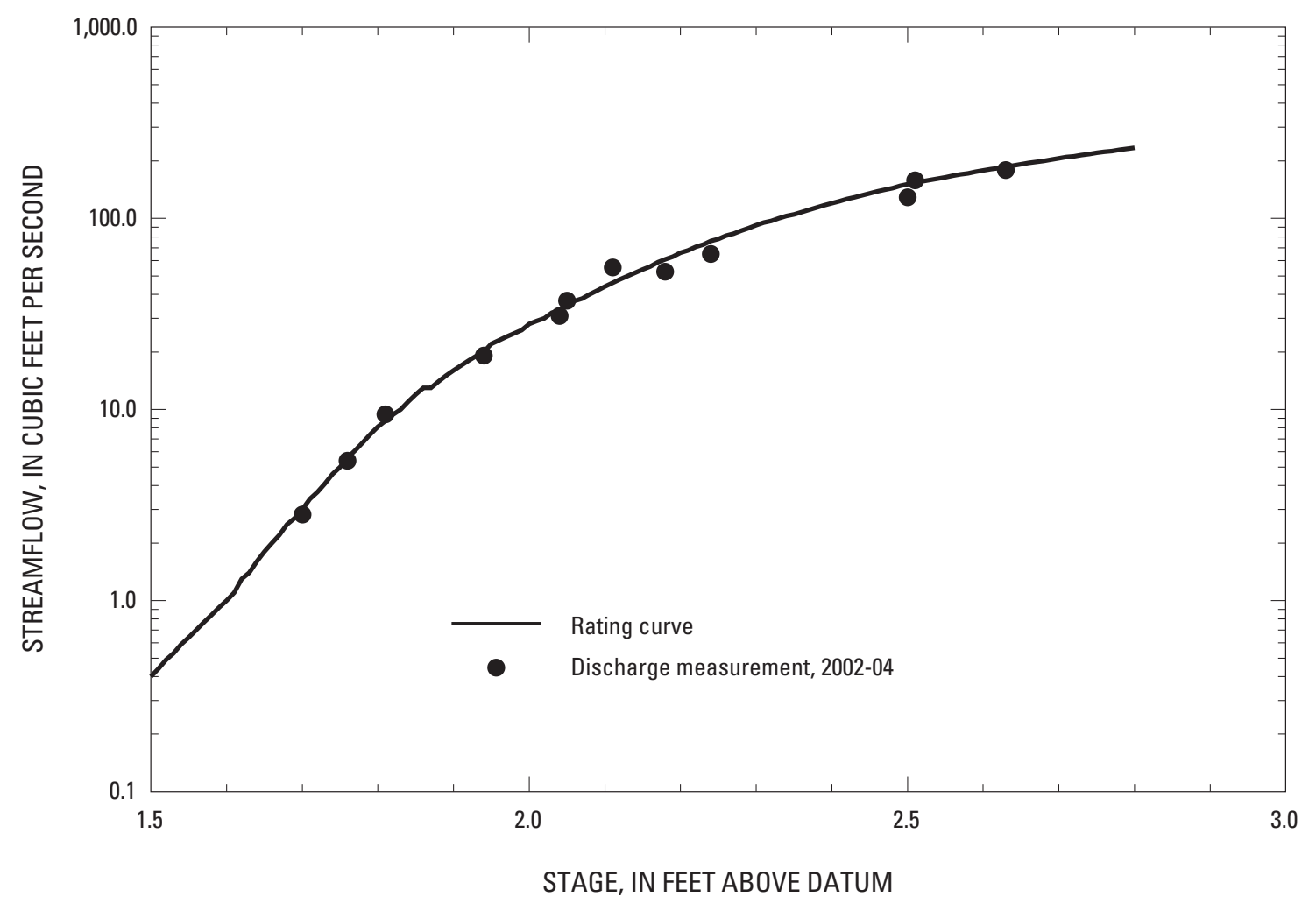

Figure 1-1. Rating curve and streamflow measurements of the Little Bush Kill at Bushkill, Pa. (station 01439680), $2002-04$.

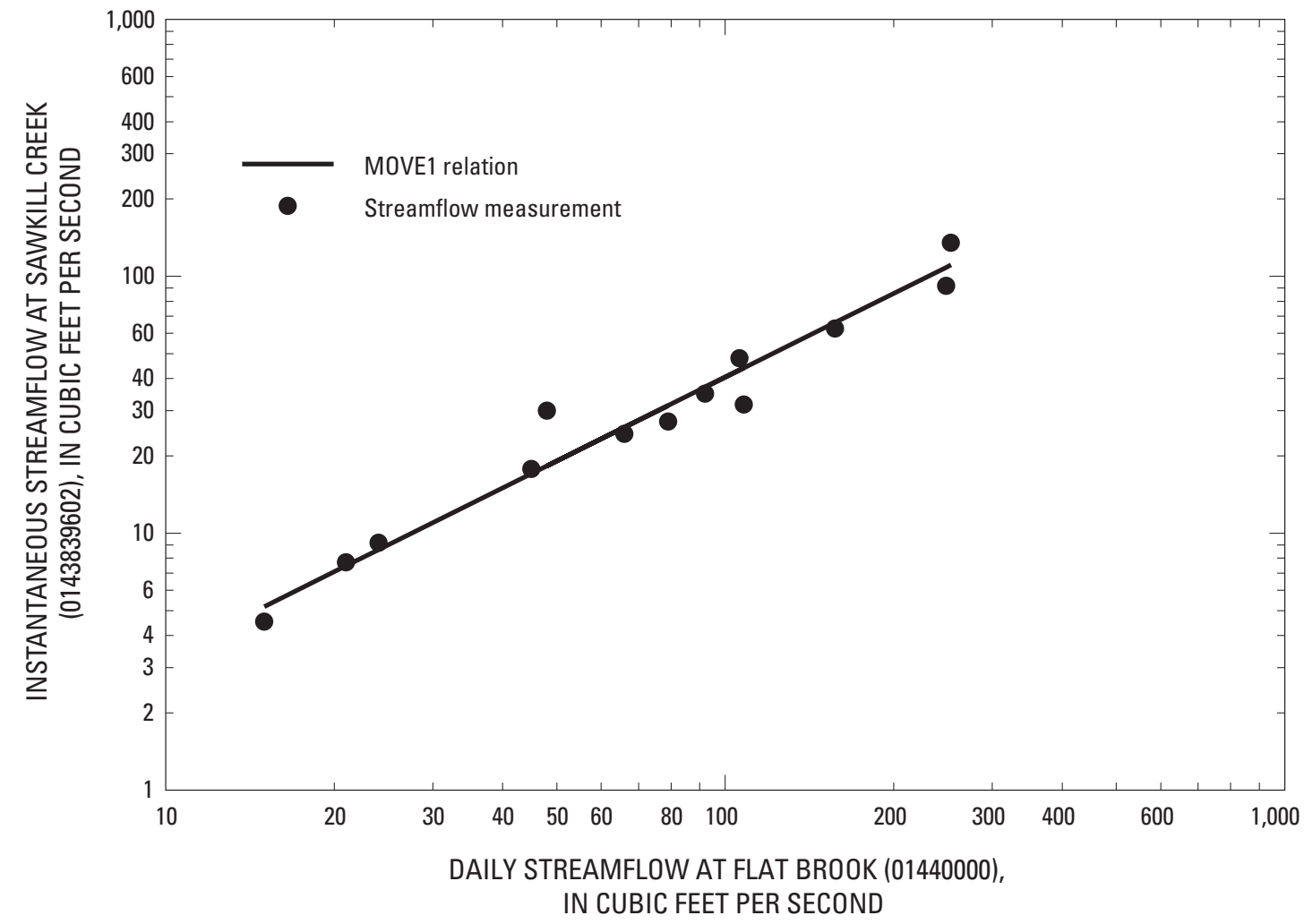

Figure 1-2. Relation between instantaneous streamflow of Sawkill Creek 1000 feet above mouth at Milford, Pa. (station 0143839602), and daily streamflow of Flat Brook at Flatbrookville, N.J. (station 01440000), 2002-04. 


\section{Appendix 2. A brief description of Tobit regression}

Tobit regression (described in Judge and others, 1980) was used to develop all linear relations discussed in this report. All the relations are of the following form:

$$
y_{i}^{*}=\Sigma B_{j} x_{j i}+e_{i}
$$

where

$$
\begin{aligned}
y_{i}^{*}= & \text { value of experimental variable } y \text { in } \\
& \text { observation } i \text { (nondetect values are set } \\
& \text { equal to the reporting level), } \\
B_{j}= & \text { coefficient for explanatory variable } j, \\
x_{j i}= & \text { value of explanatory variable } j \text { in } \\
& \text { observation } i, \text { and } \\
e_{i}= & \text { residual for observation } i .
\end{aligned}
$$

Tobit regression uses maximum likelihood estimation and iterative solutions to maximize the likelihood function in equation 2-2. The calculations, conducted with the Lifereg procedure (SAS Institute, Inc., 1999b), include estimating values for the residuals $\left(e_{i}\right)$ as well as for the coefficients $\left(B_{i}\right)$ in equation $2-1$. Residuals are assumed to have a normal distribution and constant variance across the range of predicted values.

$$
L=\Pi\left[p\left(e_{i}\right)^{\delta_{i}} \times F\left(e_{i}\right)^{1-\delta_{i}}\right]
$$

where

$$
\begin{aligned}
L= & \text { likelihood, } \\
p\left(e_{i}\right)= & \text { the probability density function of the } \\
& \text { residuals, } \\
F\left(e_{i}\right)= & \text { the cumulative distribution function of the } \\
& \text { residuals, } \\
e_{i}= & \text { residual for observation } i, \text { and } \\
\delta_{i}= & 0 \text { for an observation } i \text { with a nondetect } \\
& \text { value of } y, \text { or } \\
= & 1 \text { for an observation } i \text { with a detected value } \\
& \text { of } y .
\end{aligned}
$$

The goodness of fit of the relation to the measured values is indicated by the value of "scale." Scale is equivalent to mean square error of least-squares regression.

The Tobit relation may be strongly affected by outliers (Helsel and Hirsch, 1992). How well the values fit the linear equation and whether the residuals have constant variance and normality were evaluated as part of this report.

\section{References Cited}

Helsel, D.R., and Hirsch, R.M., 1992, Statistical methods in water resources: New York, Elsevier Science Publishing Company, Inc., 522 p.

Judge, G.G., Griffiths, W.E., Hill, R.C., and Lee, T.-C., 1980, The theory and practice of econometrics: New York, John Wiley and Sons, $793 \mathrm{p}$.

SAS Institute, Inc., 1999b, The Lifereg Procedure: Cary, N.C., SAS/STAT User's Guide, Version 8, p. 1761-1796. 


\section{Appendix 3. Summary statistics for water-quality characteristics in samples from water-quality monitoring stations on streams in and near the Delaware Water Gap National Recreation Area, Pa. and N.J., 2002-04.}

\begin{tabular}{lc}
\hline \multicolumn{1}{c}{ Index } & \\
\hline \multicolumn{1}{c}{ Water-quality characteristic } & Table \\
\hline Dissolved oxygen & $3-1$ \\
Specific conductance & $3-2$ \\
$\mathrm{pH}$ & $3-3$ \\
Attenuation turbidity & $3-4$ \\
\hline \multicolumn{2}{c}{ Plant nutrients } \\
\hline Total phosphorus & $3-5$ \\
Dissolved orthophosphate phosphorus & $3-6$ \\
Total nitrogen & $3-7$ \\
Dissolved nitrate plus nitrite & $3-8$ \\
Dissolved ammonia & $3-9$ \\
\hline \multicolumn{2}{c}{ Major ions } \\
Acid-neutralizing capacity & $3-10$ \\
Dissolved calcium & $3-11$ \\
Dissolved chloride & $3-12$ \\
\hline
\end{tabular}


Table 3-1. Summary statistics for dissolved oxygen concentrations in samples from water-quality monitoring stations on streams in and near the Delaware Water Gap National Recreation Area, Pa. and N.J., July-September, 2002-04.

[Stations are listed in order of short name; greatest reporting level of nondetect values, minimum, median, and maximum are in percent of saturation; n.a., not applicable]

\begin{tabular}{|c|c|c|c|c|c|c|c|c|}
\hline Short name & $\begin{array}{l}\text { Station } \\
\text { number }\end{array}$ & $\begin{array}{l}\text { Number of } \\
\text { measure- } \\
\text { ments }\end{array}$ & $\begin{array}{c}\text { Number of } \\
\text { nondetect } \\
\text { values }\end{array}$ & $\begin{array}{c}\text { Percentage of } \\
\text { measurements } \\
\text { that are nonde- } \\
\text { tect values }\end{array}$ & $\begin{array}{c}\text { Greatest } \\
\text { reporting level } \\
\text { of nondetect } \\
\text { values }\end{array}$ & Minimum & Median & Maximum \\
\hline Adams Creek & 01438754 & 18 & 0 & 0 & n.a. & 83 & 91 & 99 \\
\hline Big Flat Brook & 01439830 & 18 & 0 & 0 & n.a. & 84 & 97 & 104 \\
\hline Dingmans Creek & 01438892 & 18 & 0 & 0 & n.a. & 83 & 95 & 103 \\
\hline Hornbecks Creek & 01439092 & 18 & 0 & 0 & n.a. & 71 & 82 & 95 \\
\hline Little Bush Kill & 01439680 & 18 & 0 & 0 & n.a. & 85 & 97 & 100 \\
\hline Little Flat Br & 01439920 & 18 & 0 & 0 & n.a. & 77 & 93 & 127 \\
\hline Sawkill Creek & 0143839602 & 18 & 0 & 0 & n.a. & 88 & 98 & 102 \\
\hline Shimers Brook & 01438400 & 18 & 0 & 0 & n.a. & 90 & 97 & 107 \\
\hline Toms Creek & 01439400 & 19 & 0 & 0 & n.a. & 80 & 95 & 105 \\
\hline Vancampens Br & 01440100 & 18 & 0 & 0 & n.a. & 85 & 93 & 100 \\
\hline Vandermark $\mathrm{Cr}$ & 01438301 & 18 & 0 & 0 & n.a. & 34 & 95 & 101 \\
\hline
\end{tabular}


Table 3-2. Summary statistics for specific conductance in samples from water-quality monitoring stations on streams in and near the Delaware Water Gap National Recreation Area, Pa. and N.J., 2002-04.

[Stations are listed in order of short name; greatest reporting level of nondetect values, minimum, median, and maximum are in microsiemens per centimeter at 25 degrees Celsius; n.a., not applicable]

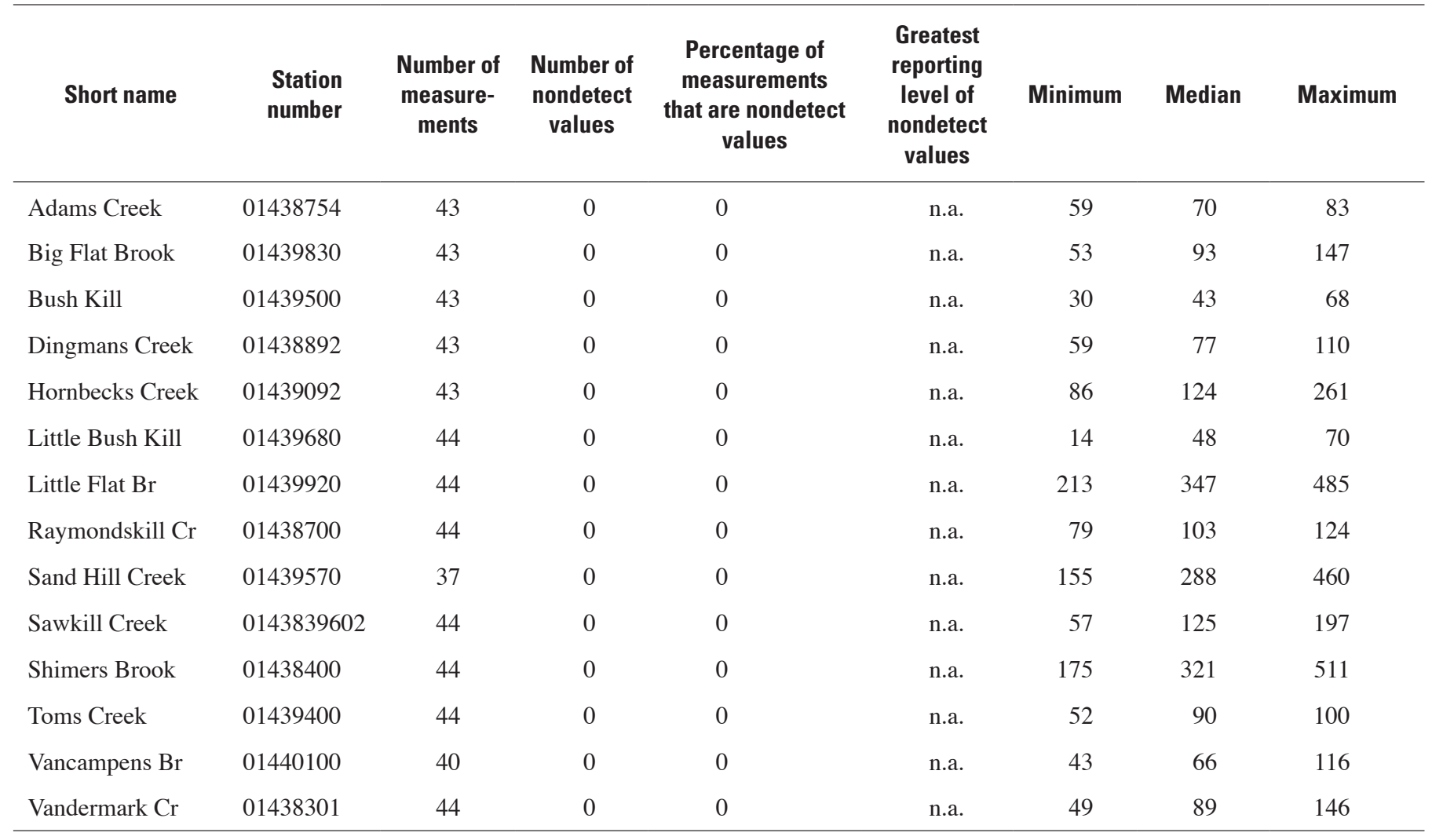


Table 3-3. Summary statistics for $\mathrm{pH}$ in samples from water-quality monitoring stations on streams in and near the Delaware Water Gap National Recreation Area, Pa. and N.J., 2002-04.

[Stations are listed in order of short name; greatest reporting level of nondetect values, minimum, median, and maximum are in standard units; n.a., not applicable]

\begin{tabular}{|c|c|c|c|c|c|c|c|c|}
\hline Short name & $\begin{array}{l}\text { Station } \\
\text { number }\end{array}$ & $\begin{array}{c}\text { Number of } \\
\text { measure- } \\
\text { ments }\end{array}$ & $\begin{array}{c}\text { Number of } \\
\text { nondetect } \\
\text { values }\end{array}$ & $\begin{array}{c}\text { Percentage of } \\
\text { measurements } \\
\text { that are nondetect } \\
\text { values }\end{array}$ & $\begin{array}{c}\text { Greatest } \\
\text { reporting level } \\
\text { of nondetect } \\
\text { values }\end{array}$ & Minimum & Median & Maximum \\
\hline Adams Creek & 01438754 & 43 & 0 & 0 & n.a. & 5.9 & 6.6 & 7.2 \\
\hline Big Flat Brook & 01439830 & 44 & 0 & 0 & n.a. & 6.2 & 7.4 & 8.2 \\
\hline Dingmans Creek & 01438892 & 44 & 0 & 0 & n.a. & 6 & 6.7 & 7.6 \\
\hline Hornbecks Creek & 01439092 & 44 & 0 & 0 & n.a. & 5.2 & 6.4 & 7.3 \\
\hline Little Bush Kill & 01439680 & 44 & 0 & 0 & n.a. & 5.4 & 6.8 & 7.5 \\
\hline Little Flat Br & 01439920 & 44 & 0 & 0 & n.a. & 7.3 & 7.8 & 8.6 \\
\hline Sawkill Creek & 0143839602 & 44 & 0 & 0 & n.a. & 5.7 & 7.1 & 7.7 \\
\hline Shimers Brook & 01438400 & 43 & 0 & 0 & n.a. & 7.5 & 8.2 & 8.6 \\
\hline Toms Creek & 01439400 & 45 & 0 & 0 & n.a. & 6.2 & 7.1 & 7.6 \\
\hline Vancampens Br & 01440100 & 40 & 0 & 0 & n.a. & 6.1 & 7.1 & 7.9 \\
\hline Vandermark $\mathrm{Cr}$ & 01438301 & 43 & 0 & 0 & n.a. & 6.1 & 7.1 & 7.8 \\
\hline
\end{tabular}


Table 3-4. Summary statistics for attenuation turbidity in samples from water-quality monitoring stations on streams in and near the Delaware Water Gap National Recreation Area, Pa. and N.J., 2002-04.

[Stations are listed in order of short name; greatest reporting level of nondetect values, minimum, median, and maximum are in attenuation units; n.a., not applicable]

\begin{tabular}{|c|c|c|c|c|c|c|c|c|}
\hline Short name & $\begin{array}{l}\text { Station } \\
\text { number }\end{array}$ & $\begin{array}{l}\text { Number of } \\
\text { measure- } \\
\text { ments }\end{array}$ & $\begin{array}{c}\text { Number of } \\
\text { nondetect } \\
\text { values }\end{array}$ & $\begin{array}{c}\text { Percentage of } \\
\text { measurements } \\
\text { that are nonde- } \\
\text { tect values }\end{array}$ & $\begin{array}{c}\text { Greatest } \\
\text { reporting level } \\
\text { of nondetect } \\
\text { values }\end{array}$ & Minimum & Median & Maximum \\
\hline Adams Creek & 01438754 & 43 & 0 & 0 & n.a. & 5 & 7 & 17 \\
\hline Big Flat Brook & 01439830 & 42 & 0 & 0 & n.a. & 4 & 8 & 66 \\
\hline Dingmans Creek & 01438892 & 43 & 0 & 0 & n.a. & 2 & 11 & 24 \\
\hline Hornbecks Creek & 01439092 & 43 & 0 & 0 & n.a. & 6 & 9 & 21 \\
\hline Little Bush Kill & 01439680 & 43 & 0 & 0 & n.a. & 7 & 20 & 45 \\
\hline Little Flat Br & 01439920 & 41 & 0 & 0 & n.a. & 7 & 12 & 53 \\
\hline Sawkill Creek & 0143839602 & 43 & 0 & 0 & n.a. & 2 & 8 & 69 \\
\hline Shimers Brook & 01438400 & 42 & 0 & 0 & n.a. & 3 & 12 & 41 \\
\hline Toms Creek & 01439400 & 43 & 0 & 0 & n.a. & 3 & 5 & 27 \\
\hline Vancampens Br & 01440100 & 38 & 0 & 0 & n.a. & 3 & 6 & 9 \\
\hline Vandermark $\mathrm{Cr}$ & 01438301 & 42 & 0 & 0 & n.a. & 2 & 7 & 64 \\
\hline
\end{tabular}


Table 3-5. Summary statistics for total phosphorus in samples from water-quality monitoring stations on streams in and near the Delaware Water Gap National Recreation Area, Pa. and N.J., 2002-04.

[Stations are listed in order of short name; greatest reporting level of nondetect values, minimum, median, and maximum are in milligrams per liter as P; E, estimated; n.a., not applicable]

\begin{tabular}{|c|c|c|c|c|c|c|c|c|}
\hline Short name & $\begin{array}{l}\text { Station } \\
\text { number }\end{array}$ & $\begin{array}{c}\text { Number of } \\
\text { measure- } \\
\text { ments }\end{array}$ & $\begin{array}{c}\text { Number of } \\
\text { nondetect } \\
\text { values }\end{array}$ & $\begin{array}{l}\text { Percentage of } \\
\text { measurements } \\
\text { that are non- } \\
\text { detect values }\end{array}$ & $\begin{array}{c}\text { Greatest re- } \\
\text { porting level } \\
\text { of nondetect } \\
\text { values }\end{array}$ & Minimum & Median & Maximum \\
\hline Adams Creek & 01438754 & 44 & 0 & 0 & n.a. & E 0.004 & 0.014 & 0.073 \\
\hline Big Flat Brook & 01439830 & 44 & 0 & 0 & n.a. & .005 & .011 & .182 \\
\hline Dingmans Creek & 01438892 & 44 & 0 & 0 & n.a. & .007 & .016 & .031 \\
\hline Hornbecks Creek & 01439092 & 44 & 0 & 0 & n.a. & .006 & .016 & .084 \\
\hline Little Bush Kill & 01439680 & 44 & 0 & 0 & n.a. & .011 & .02 & .044 \\
\hline Little Flat Br & 01439920 & 44 & 0 & 0 & n.a. & .007 & .025 & .176 \\
\hline Sawkill Creek & 0143839602 & 44 & 0 & 0 & n.a. & .008 & .017 & .189 \\
\hline Shimers Brook & 01438400 & 44 & 0 & 0 & n.a. & .009 & .019 & .102 \\
\hline Toms Creek & 01439400 & 45 & 0 & 0 & n.a. & E.003 & .011 & .069 \\
\hline Vancampens Br & 01440100 & 39 & 0 & 0 & n.a. & E.003 & .008 & .016 \\
\hline Vandermark $\mathrm{Cr}$ & 01438301 & 44 & 0 & 0 & n.a. & .01 & .023 & .084 \\
\hline
\end{tabular}


Table 3-6. Summary statistics for dissolved orthophosphate phosphorus in samples from water-quality monitoring stations on streams in and near the Delaware Water Gap National Recreation Area, Pa. and N.J., 2002-04.

[Stations are listed in order of short name; greatest reporting level of nondetect values, minimum, median, and maximum are in milligrams per liter as P; $<$, less than; E, estimated]

\begin{tabular}{|c|c|c|c|c|c|c|c|c|}
\hline Short name & $\begin{array}{l}\text { Station } \\
\text { number }\end{array}$ & $\begin{array}{c}\text { Number of } \\
\text { measure- } \\
\text { ments }\end{array}$ & $\begin{array}{c}\text { Number of } \\
\text { nondetect } \\
\text { values }\end{array}$ & $\begin{array}{c}\text { Percentage of } \\
\text { measurements } \\
\text { that are nonde- } \\
\text { tect values }\end{array}$ & $\begin{array}{c}\text { Greatest re- } \\
\text { porting level } \\
\text { of nondetect } \\
\text { values }\end{array}$ & Minimum & Median & Maximum \\
\hline Adams Creek & 01438754 & 43 & 33 & 77 & 0.02 & $<0.003$ & 0.002 & E 0.01 \\
\hline Big Flat Brook & 01439830 & 43 & 40 & 93 & .01 & $<.003$ & $<.01$ & E. .004 \\
\hline Dingmans Creek & 01438892 & 44 & 30 & 68 & .02 & $<.003$ & .003 & E.02 \\
\hline Hornbecks Creek & 01439092 & 44 & 40 & 91 & .02 & $<.003$ & $<.02$ & E.004 \\
\hline Little Bush Kill & 01439680 & 44 & 22 & 50 & .01 & $<.003$ & .01 & .013 \\
\hline Little Flat Br & 01439920 & 44 & 18 & 41 & .01 & $<.003$ & .01 & .04 \\
\hline Shimers Brook & 01438400 & 44 & 28 & 64 & .01 & $<.003$ & .003 & .02 \\
\hline Toms Creek & 01439400 & 45 & 22 & 49 & .01 & $<.003$ & .01 & E.01 \\
\hline Vancampens Br & 01440100 & 39 & 29 & 74 & .01 & $<.003$ & .003 & E.01 \\
\hline Vandermark Cr & 01438301 & 44 & 3 & 7 & .01 & $<.01$ & .012 & .04 \\
\hline
\end{tabular}


Table 3-7. Summary statistics for measurements of total nitrogen at stations on streams in and near the Delaware Water Gap National Recreation Area, 2002-2004.

[Stations are listed in order of short name; greatest reporting level of nondetect values, minimum, median, and maximum are in milligrams per liter as $\mathrm{N}$; $<$, less than]

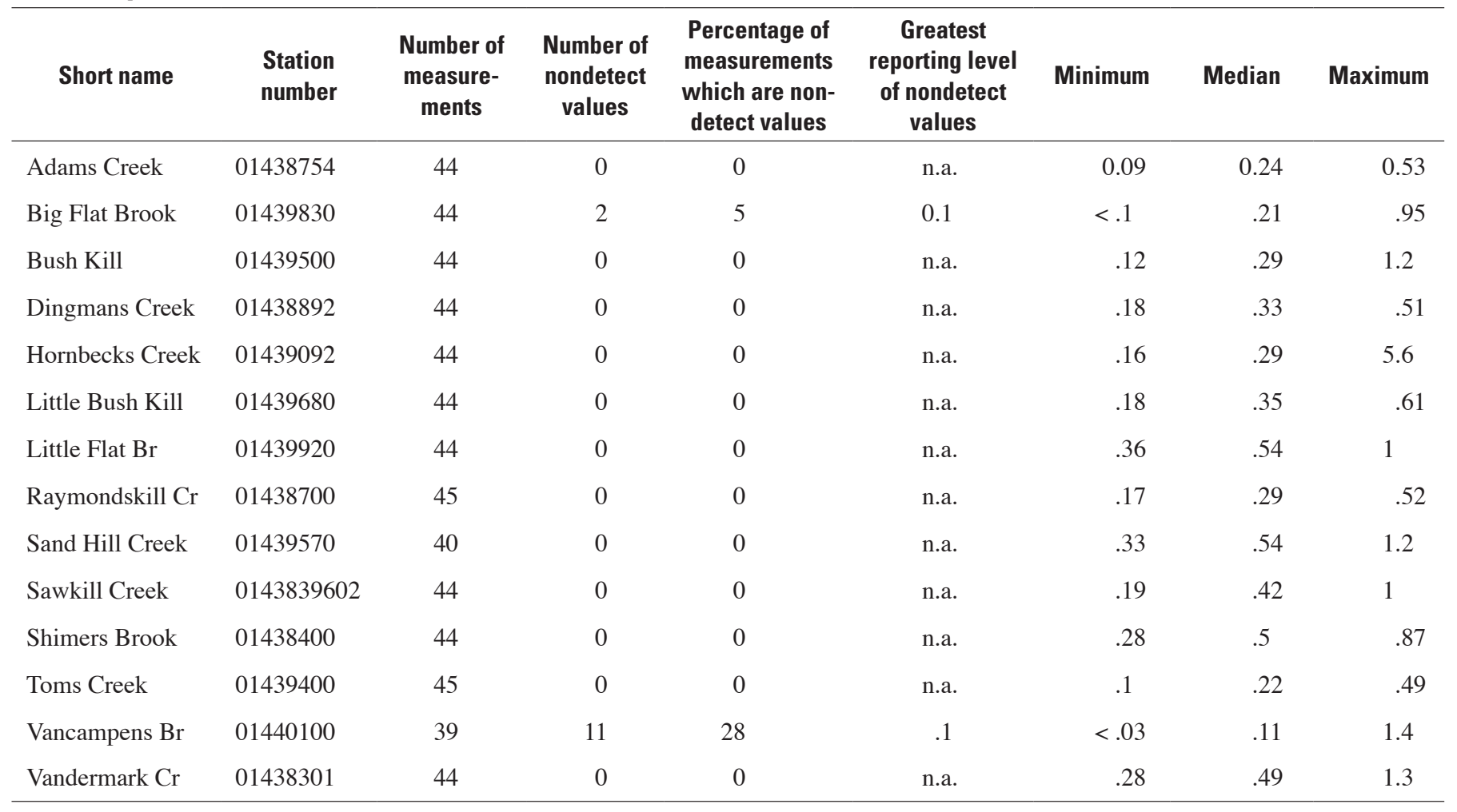


Table 3-8. Summary statistics for dissolved nitrate plus nitrite in samples from water-quality monitoring stations on streams in and near the Delaware Water Gap National Recreation Area, Pa. and N.J., 2002-04.

[Stations are listed in order of short name; greatest reporting level of nondetect values, minimum, median, and maximum are in milligrams per liter as $\mathrm{N}$; n.a., not applicable; <, less than; E, estimated]

\begin{tabular}{|c|c|c|c|c|c|c|c|c|}
\hline Short name & $\begin{array}{l}\text { Station } \\
\text { number }\end{array}$ & $\begin{array}{c}\text { Number of } \\
\text { measure- } \\
\text { ments }\end{array}$ & $\begin{array}{c}\text { Number of } \\
\text { nondetect } \\
\text { values }\end{array}$ & $\begin{array}{c}\text { Percentage of } \\
\text { measurements } \\
\text { that are non- } \\
\text { detect values }\end{array}$ & $\begin{array}{c}\text { Greatest } \\
\text { reporting level } \\
\text { of nondetect } \\
\text { values }\end{array}$ & Minimum & Median & Maximum \\
\hline Adams Creek & 01438754 & 43 & 11 & 26 & 0.03 & $<0.03$ & 0.06 & 0.23 \\
\hline Big Flat Brook & 01439830 & 44 & 17 & 39 & .03 & $<.025$ & .04 & .25 \\
\hline Dingmans Creek & 01438892 & 44 & 2 & 5 & .03 & $<.03$ & .08 & .32 \\
\hline Hornbecks Creek & 01439092 & 44 & 3 & 7 & .03 & $<.025$ & .08 & 5.35 \\
\hline Little Bush Kill & 01439680 & 44 & 7 & 16 & .03 & $<.025$ & .06 & .25 \\
\hline Little Flat Br & 01439920 & 44 & 0 & 0 & n.a. & .07 & .29 & .5 \\
\hline Shimers Brook & 01438400 & 44 & 0 & 0 & n.a. & .08 & .2 & .34 \\
\hline Toms Creek & 01439400 & 45 & 0 & 0 & n.a. & E.04 & .14 & .33 \\
\hline Vancampens $\mathrm{Br}$ & 01440100 & 39 & 23 & 59 & .03 & $<.025$ & .03 & .13 \\
\hline Vandermark $\mathrm{Cr}$ & 01438301 & 44 & 1 & 2 & .025 & $<.025$ & .37 & 1.3 \\
\hline
\end{tabular}


Table 3-9. Summary statistics for dissolved ammonia in samples from water-quality monitoring stations on streams in and near the Delaware Water Gap National Recreation Area, Pa. and N.J., 2002-04.

[Stations are listed in order of short name; greatest reporting level of nondetect values, minimum, median, and maximum are in milligrams per liter as $\mathrm{N} ;<$, less than; E, estimated]

\begin{tabular}{|c|c|c|c|c|c|c|c|c|}
\hline Short name & $\begin{array}{l}\text { Station } \\
\text { number }\end{array}$ & $\begin{array}{c}\text { Number of } \\
\text { measure- } \\
\text { ments }\end{array}$ & $\begin{array}{c}\text { Number of } \\
\text { nondetect } \\
\text { values }\end{array}$ & $\begin{array}{l}\text { Percentage of } \\
\text { measurements } \\
\text { that are nonde- } \\
\text { tect values }\end{array}$ & $\begin{array}{l}\text { Greatest } \\
\text { reporting } \\
\text { level of } \\
\text { nondetect } \\
\text { values }\end{array}$ & Minimum & Median & Maximum \\
\hline Adams Creek & 01438754 & 43 & 29 & 67 & 0.0075 & $<0.005$ & 0.004 & 0.03 \\
\hline Big Flat Brook & 01439830 & 44 & 40 & 91 & .0075 & $<.005$ & $<.0075$ & .018 \\
\hline Dingmans Creek & 01438892 & 44 & 30 & 68 & .0075 & $<.005$ & .005 & .029 \\
\hline Hornbecks Creek & 01439092 & 44 & 17 & 39 & .0075 & $<.005$ & .008 & .064 \\
\hline Little Bush Kill & 01439680 & 44 & 28 & 64 & .0075 & $<.005$ & .005 & .084 \\
\hline Sawkill Creek & 0143839602 & 44 & 37 & 84 & .0075 & $<.005$ & $<.0075$ & E.009 \\
\hline Shimers Brook & 01438400 & 44 & 29 & 66 & .0075 & $<.005$ & .005 & .025 \\
\hline Toms Creek & 01439400 & 45 & 43 & 96 & .02 & $<.005$ & $<.02$ & E. .005 \\
\hline Vancampens Br & 01440100 & 38 & 37 & 97 & .0075 & $<.005$ & $<.0075$ & E.005 \\
\hline Vandermark $\mathrm{Cr}$ & 01438301 & 44 & 39 & 89 & .0075 & $<.005$ & $<.0075$ & E.01 \\
\hline
\end{tabular}


Table 3-10. Summary statistics for acid-neutralizing capacity in samples from water-quality monitoring stations on streams in and near the Delaware Water Gap National Recreation Area, Pa. and N.J., 2002-04.

[Stations are listed in order of short name; greatest reporting level of nondetect values, minimum, median, and maximum are in milligrams per liter as $\mathrm{CaCO}_{3}$; n.a., not applicable; E, estimated]

\begin{tabular}{|c|c|c|c|c|c|c|c|c|}
\hline Short name & $\begin{array}{l}\text { Station } \\
\text { number }\end{array}$ & $\begin{array}{c}\text { Number of } \\
\text { measure- } \\
\text { ments }\end{array}$ & $\begin{array}{c}\text { Number of } \\
\text { nondetect } \\
\text { values }\end{array}$ & $\begin{array}{c}\text { Percentage of } \\
\text { measurements } \\
\text { that are nonde- } \\
\text { tect values }\end{array}$ & $\begin{array}{c}\text { Greatest re- } \\
\text { porting level } \\
\text { of nondetect } \\
\text { values }\end{array}$ & Minimum & Median & Maximum \\
\hline Adams Creek & 01438754 & 18 & 0 & 0 & n.a. & 5 & 8 & E 14 \\
\hline Big Flat Brook & 01439830 & 18 & 0 & 0 & n.a. & 9 & 17 & 39 \\
\hline Dingmans Creek & 01438892 & 18 & 0 & 0 & n.a. & 6 & 9 & E 23 \\
\hline Hornbecks Creek & 01439092 & 18 & 0 & 0 & n.a. & 7 & 11 & 18 \\
\hline Little Bush Kill & 01439680 & 18 & 0 & 0 & n.a. & 4 & 6 & 12 \\
\hline Little Flat Br & 01439920 & 18 & 0 & 0 & n.a. & 64 & 102 & E 158 \\
\hline Sawkill Creek & 0143839602 & 19 & 0 & 0 & n.a. & 8 & 12 & E 20 \\
\hline Shimers Brook & 01438400 & 18 & 0 & 0 & n.a. & 56 & 101 & E 172 \\
\hline Toms Creek & 01439400 & 19 & 0 & 0 & n.a. & 8 & 13 & E 19 \\
\hline Vancampens Br & 01440100 & 15 & 0 & 0 & n.a. & 10 & 18 & E 44 \\
\hline Vandermark Cr & 01438301 & 18 & 0 & 0 & n.a. & 6 & 11 & E 15 \\
\hline
\end{tabular}


Table 3-11. Summary statistics dissolved calcium in samples from water-quality monitoring stations on streams in and near the Delaware Water Gap National Recreation Area, Pa. and N.J., 2002-04.

[Stations are listed in order of short name; greatest reporting level of nondetect values, minimum, median, and maximum are in milligrams per liter as Ca; n.a., not applicable]

\begin{tabular}{|c|c|c|c|c|c|c|c|c|}
\hline Short name & $\begin{array}{l}\text { Station } \\
\text { number }\end{array}$ & $\begin{array}{c}\text { Number of } \\
\text { measure- } \\
\text { ments }\end{array}$ & $\begin{array}{c}\text { Number of } \\
\text { nondetect } \\
\text { values }\end{array}$ & $\begin{array}{c}\text { Percentage of } \\
\text { measurements } \\
\text { that are non- } \\
\text { detect values }\end{array}$ & $\begin{array}{c}\text { Greatest re- } \\
\text { porting level } \\
\text { of nondetect } \\
\text { values }\end{array}$ & Minimum & Median & Maximum \\
\hline Adams Creek & 01438754 & 18 & 0 & 0 & n.a. & 2.97 & 3.73 & 5.2 \\
\hline Big Flat Brook & 01439830 & 18 & 0 & 0 & n.a. & 3.99 & 6.6 & 12.3 \\
\hline Bush Kill & 01439500 & 19 & 0 & 0 & n.a. & 2.59 & 3.44 & 5.97 \\
\hline Dingmans Creek & 01438892 & 18 & 0 & 0 & n.a. & 3.32 & 4.13 & 6.96 \\
\hline Hornbecks Creek & 01439092 & 18 & 0 & 0 & n.a. & 4.63 & 5.94 & 10.1 \\
\hline Little Bush Kill & 01439680 & 18 & 0 & 0 & n.a. & 2.39 & 3.29 & 4.53 \\
\hline Little Flat Br & 01439920 & 18 & 0 & 0 & n.a. & 23.1 & 36.75 & 53.3 \\
\hline Raymondskill Cr & 01438700 & 18 & 0 & 0 & n.a. & 3.31 & 4.74 & 6.22 \\
\hline Sand Hill Creek & 01439570 & 16 & 0 & 0 & n.a. & 32.5 & 46 & 65 \\
\hline Sawkill Creek & 0143839602 & 19 & 0 & 0 & n.a. & 4.45 & 6.37 & 11.2 \\
\hline Shimers Brook & 01438400 & 18 & 0 & 0 & n.a. & 20.4 & 36.7 & 55.7 \\
\hline Toms Creek & 01439400 & 19 & 0 & 0 & n.a. & 4.53 & 6.17 & 6.9 \\
\hline Vancampens $\mathrm{Br}$ & 01440100 & 15 & 0 & 0 & n.a. & 4.05 & 6.36 & 12.7 \\
\hline Vandermark $\mathrm{Cr}$ & 01438301 & 18 & 0 & 0 & n.a. & 3.91 & 5.07 & 8.99 \\
\hline
\end{tabular}


Table 3-12. Summary statistics for dissolved chloride in samples from water-quality monitoring stations on streams in and near the Delaware Water Gap National Recreation Area, Pa. and N.J., 2002-04.

[Stations are listed in order of short name; greatest reporting level of nondetect values, minimum, median, and maximum are in milligrams per liter as $\mathrm{Cl}$; n.a., not applicable]

\begin{tabular}{|c|c|c|c|c|c|c|c|c|}
\hline Short name & $\begin{array}{l}\text { Station } \\
\text { number }\end{array}$ & $\begin{array}{c}\text { Number of } \\
\text { measure- } \\
\text { ments }\end{array}$ & $\begin{array}{c}\text { Number of } \\
\text { nondetect } \\
\text { values }\end{array}$ & $\begin{array}{c}\text { Percentage of } \\
\text { measurements } \\
\text { that are non- } \\
\text { detect values }\end{array}$ & $\begin{array}{c}\text { Greatest re- } \\
\text { porting level } \\
\text { of nondetect } \\
\text { values }\end{array}$ & Minimum & Median & Maximum \\
\hline Adams Creek & 01438754 & 18 & 0 & 0 & n.a. & 7.69 & 10.35 & 14.9 \\
\hline Big Flat Brook & 01439830 & 18 & 0 & 0 & n.a. & 4.36 & 10.4 & 16.7 \\
\hline Bush Kill & 01439500 & 19 & 0 & 0 & n.a. & 2.63 & 5.01 & 8.84 \\
\hline Dingmans Creek & 01438892 & 18 & 0 & 0 & n.a. & 8.49 & 11.05 & 15.5 \\
\hline Hornbecks Creek & 01439092 & 18 & 0 & 0 & n.a. & 12.9 & 19.7 & 53.6 \\
\hline Little Bush Kill & 01439680 & 18 & 0 & 0 & n.a. & 3.55 & 5.27 & 8.04 \\
\hline Little Flat Br & 01439920 & 18 & 0 & 0 & n.a. & 22.7 & 36.25 & 45.9 \\
\hline Raymondskill Cr & 01438700 & 18 & 0 & 0 & n.a. & 13.7 & 18.55 & 26.4 \\
\hline Sand Hill Creek & 01439570 & 16 & 0 & 0 & n.a. & 12.1 & 21.9 & 57 \\
\hline Sawkill Creek & 0143839602 & 19 & 0 & 0 & n.a. & 12.4 & 21.8 & 34.8 \\
\hline Shimers Brook & 01438400 & 18 & 0 & 0 & n.a. & 14.2 & 24.05 & 40.4 \\
\hline Toms Creek & 01439400 & 19 & 0 & 0 & n.a. & 4.76 & 10.5 & 13.7 \\
\hline Vancampens $\mathrm{Br}$ & 01440100 & 15 & 0 & 0 & n.a. & 1.97 & 2.66 & 3.68 \\
\hline Vandermark Cr & 01438301 & 18 & 0 & 0 & n.a. & 7.31 & 12.2 & 25.8 \\
\hline
\end{tabular}




\section{Appendix 4. Equations relating water quality, streamflow, and season at stations on streams in and near the Delaware Water Gap National Recreation Area, Pa. and N.J., 2002-04}

The equations relating water quality, streamflow, and season (listed in the index) are the basis for determining (a) relations between water quality and streamflow, and relations between water quality and season, and (b) changes in water quality over time. Intercepts and coefficients for streamflow and season are included. Also included are the levels of significance for each intercept and coefficient. All coefficients and the intercept remain in the equation regardless of the level of significance. Relations were determined with Tobit regression.

Relations for a water-quality characteristic at a station are not presented if certain requirements of the data were not met. These requirements are discussed in the text.

\begin{tabular}{lc}
\multicolumn{1}{c}{ Index } & \\
\multicolumn{1}{c}{ Water-quality characteristic } & Table \\
\hline \multicolumn{2}{c}{ Physical characteristics } \\
\hline Dissolved oxygen (July-September) & $4-1$ \\
Specific conductance & $4-2$ \\
$\mathrm{pH}$ & $4-3$ \\
Attenuation turbidity & $4-4$ \\
\hline \multicolumn{2}{c}{ Plant nutrients } \\
\hline Total phosphorus & $4-5$ \\
Dissolved orthophosphate phosphorus & $4-6$ \\
Total nitrogen & $4-7$ \\
Dissolved nitrate plus nitrite & $4-8$ \\
Dissolved ammonia & $4-9$ \\
\hline \multicolumn{2}{c}{ Major ions } \\
\hline Acid-neutralizing capacity & $4-10$ \\
Dissolved chloride & $4-11$ \\
Dissolved calcium & $4-12$ \\
\hline
\end{tabular}



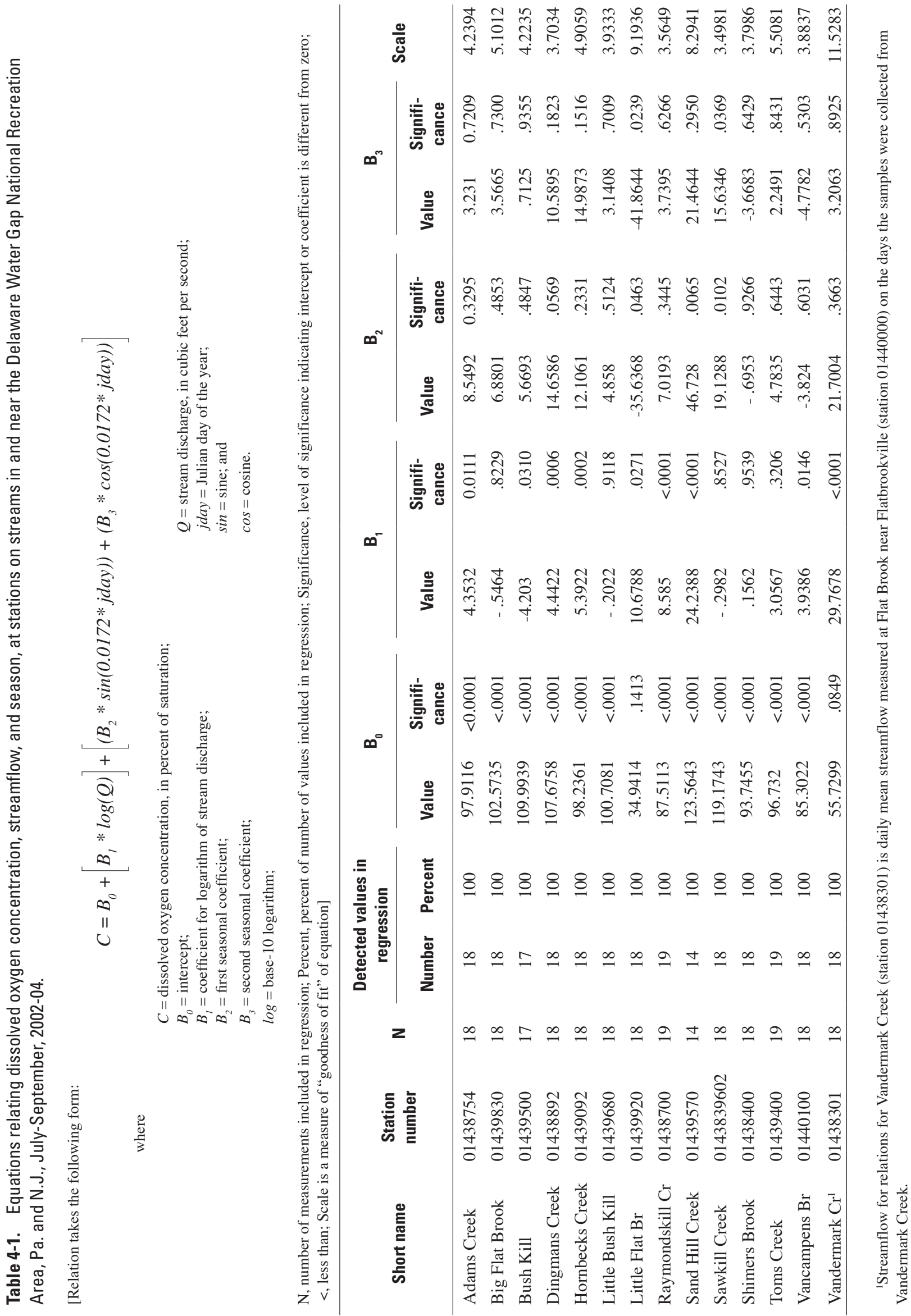

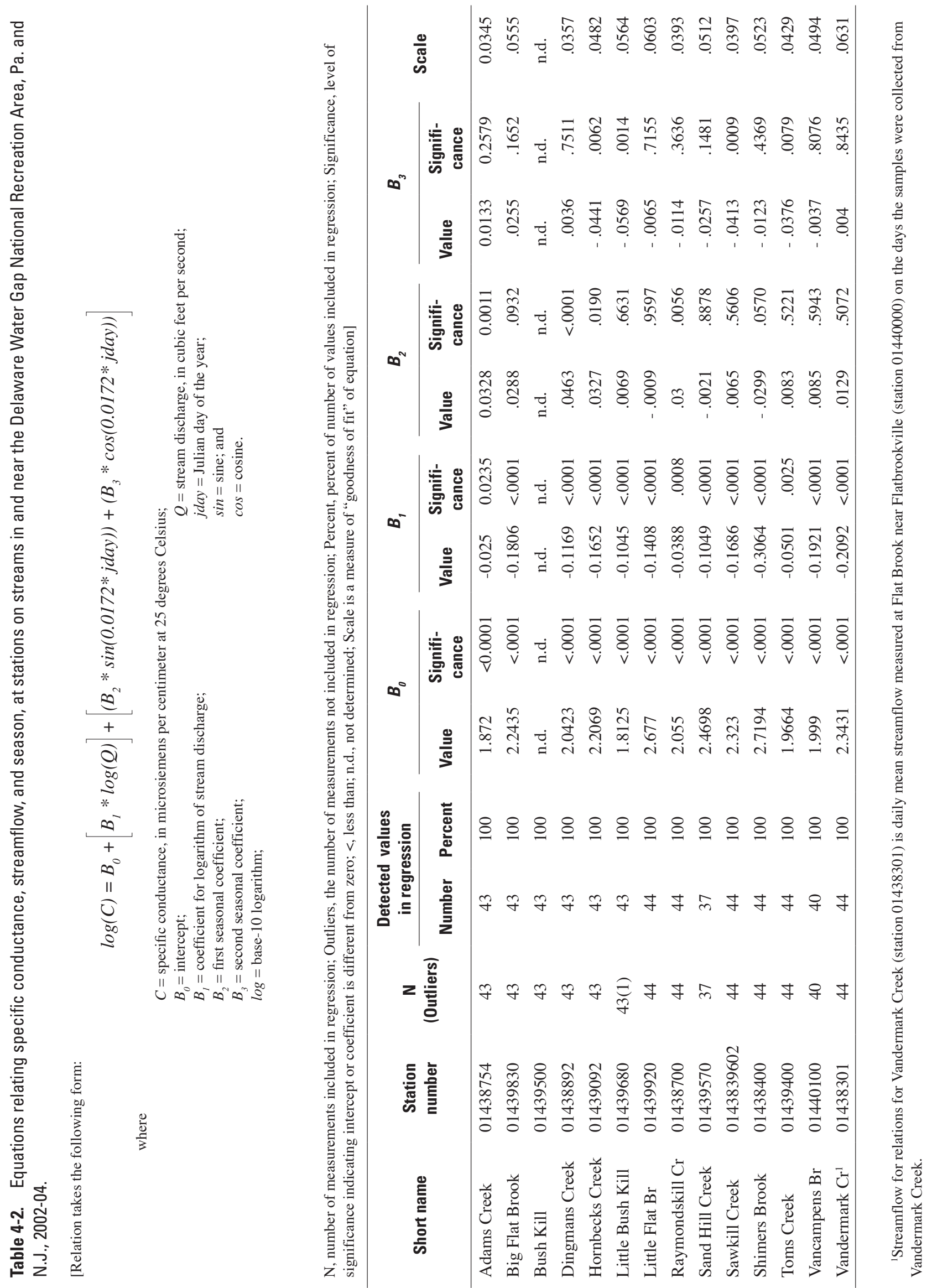

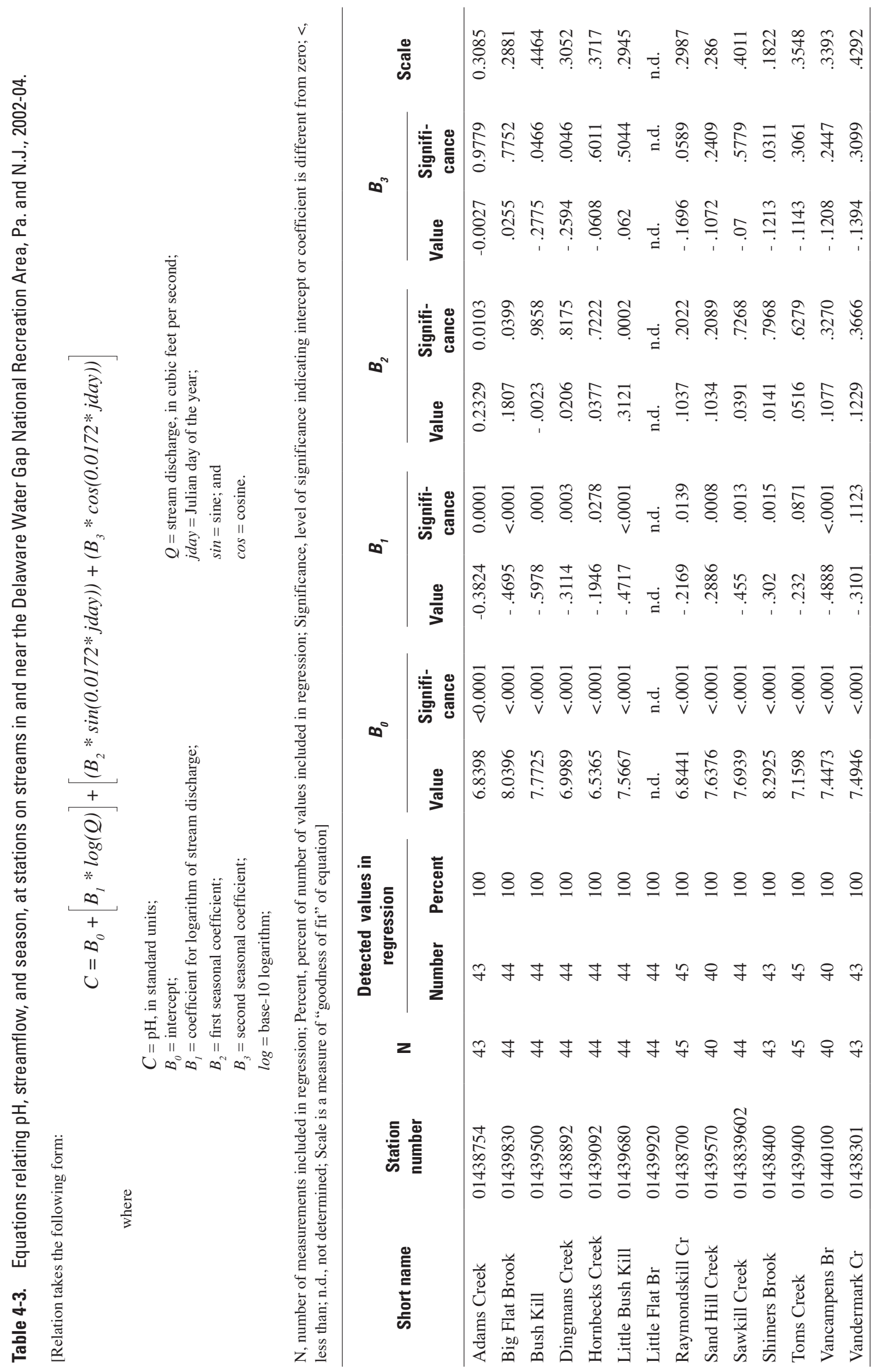

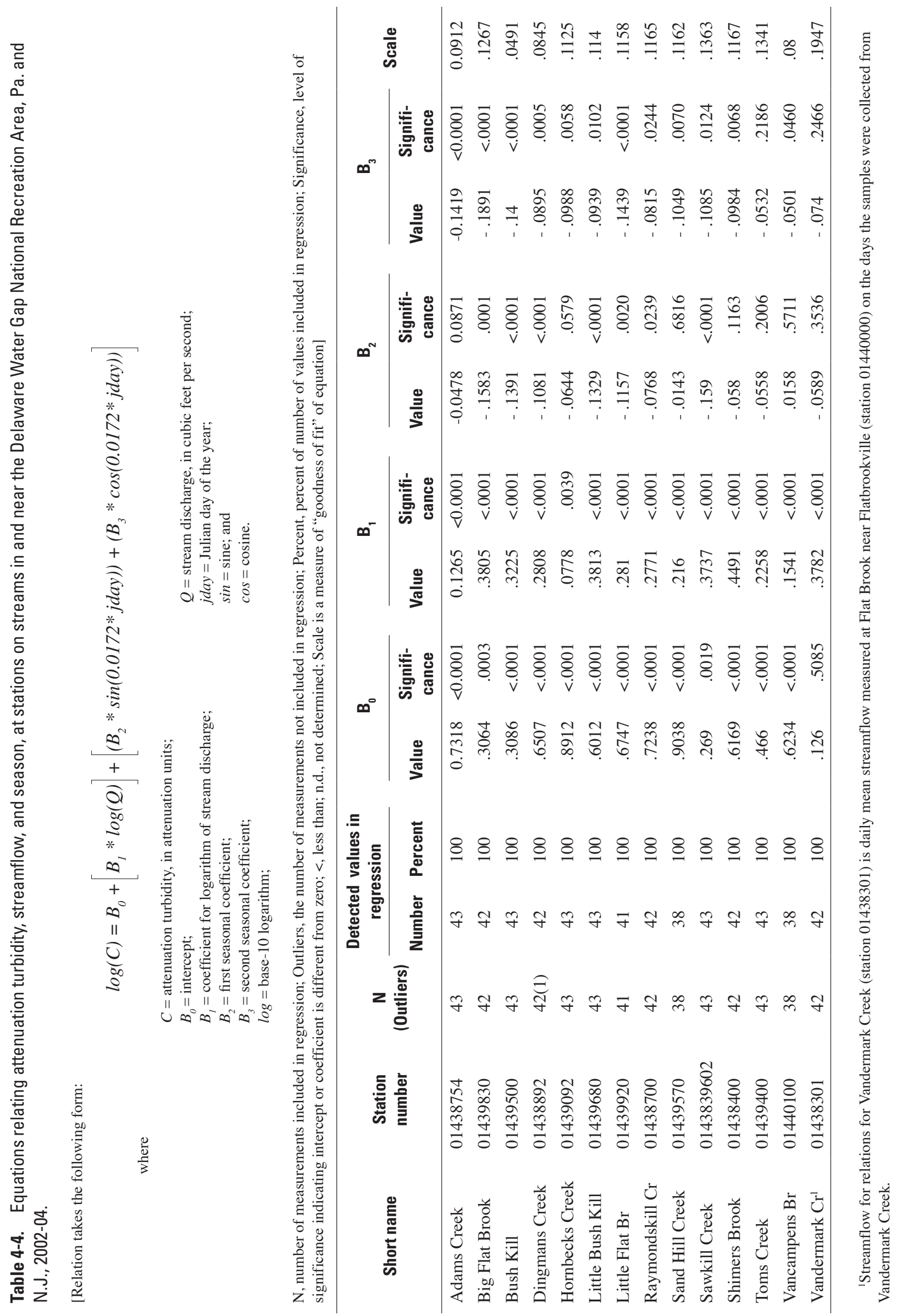

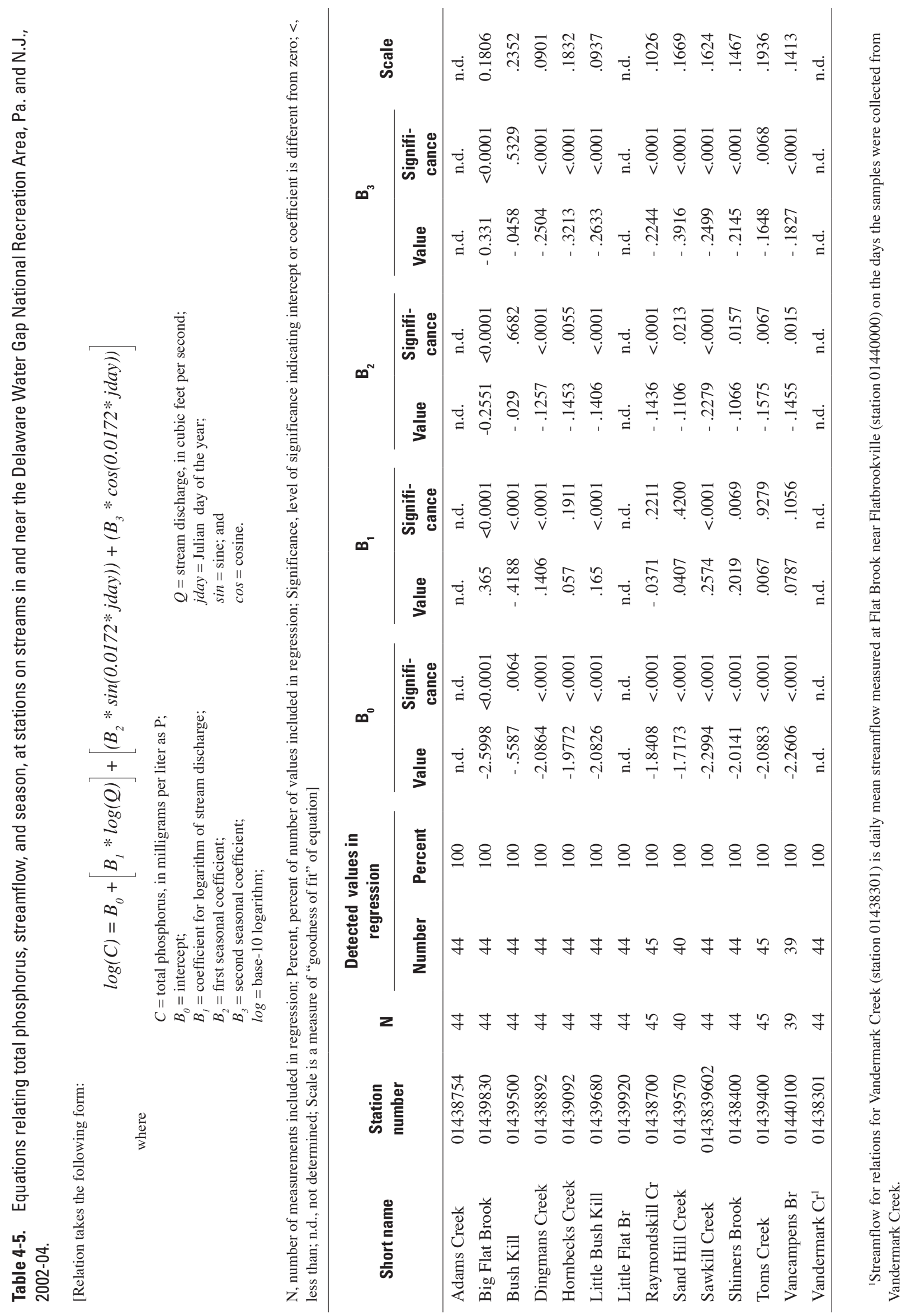

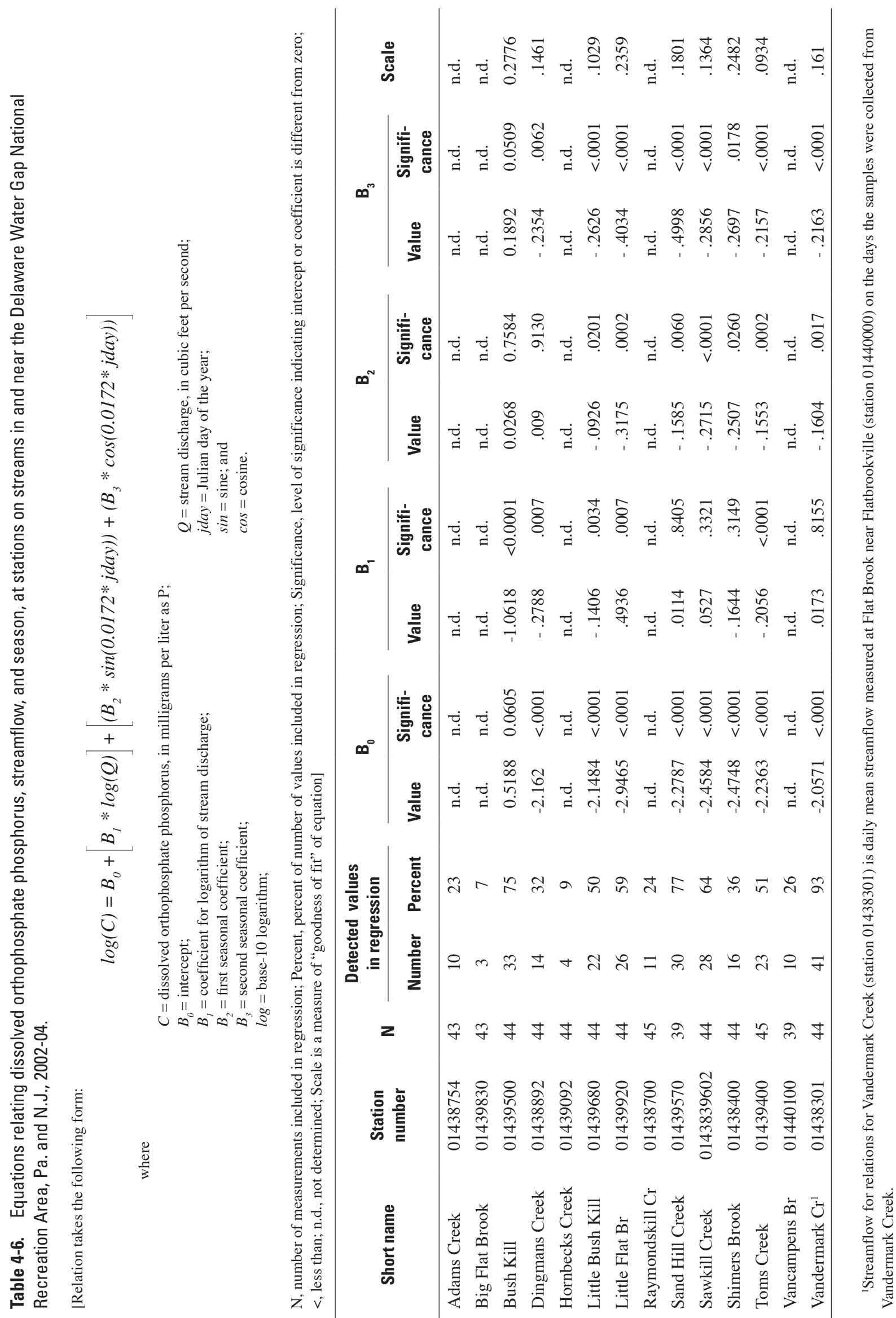

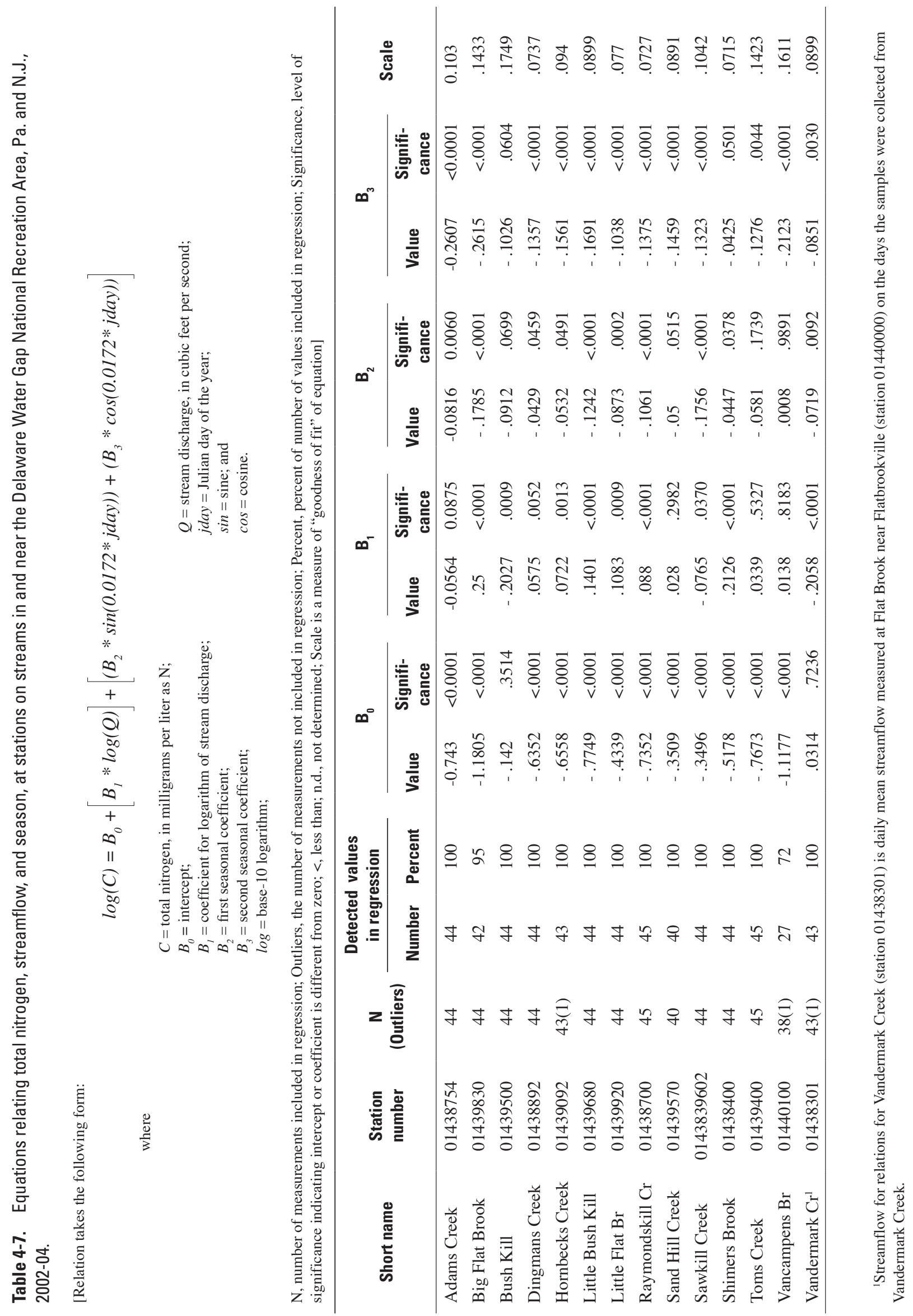

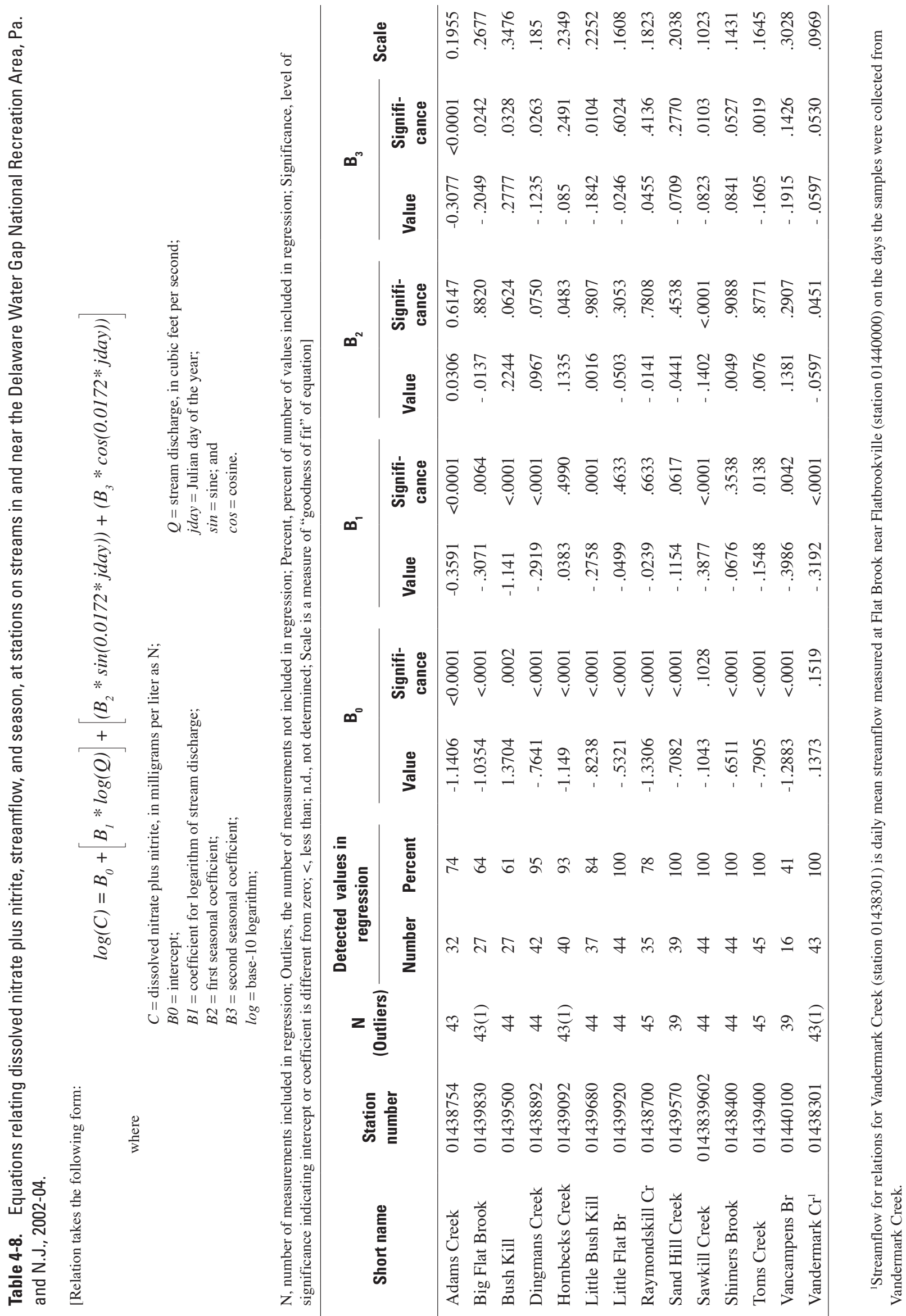

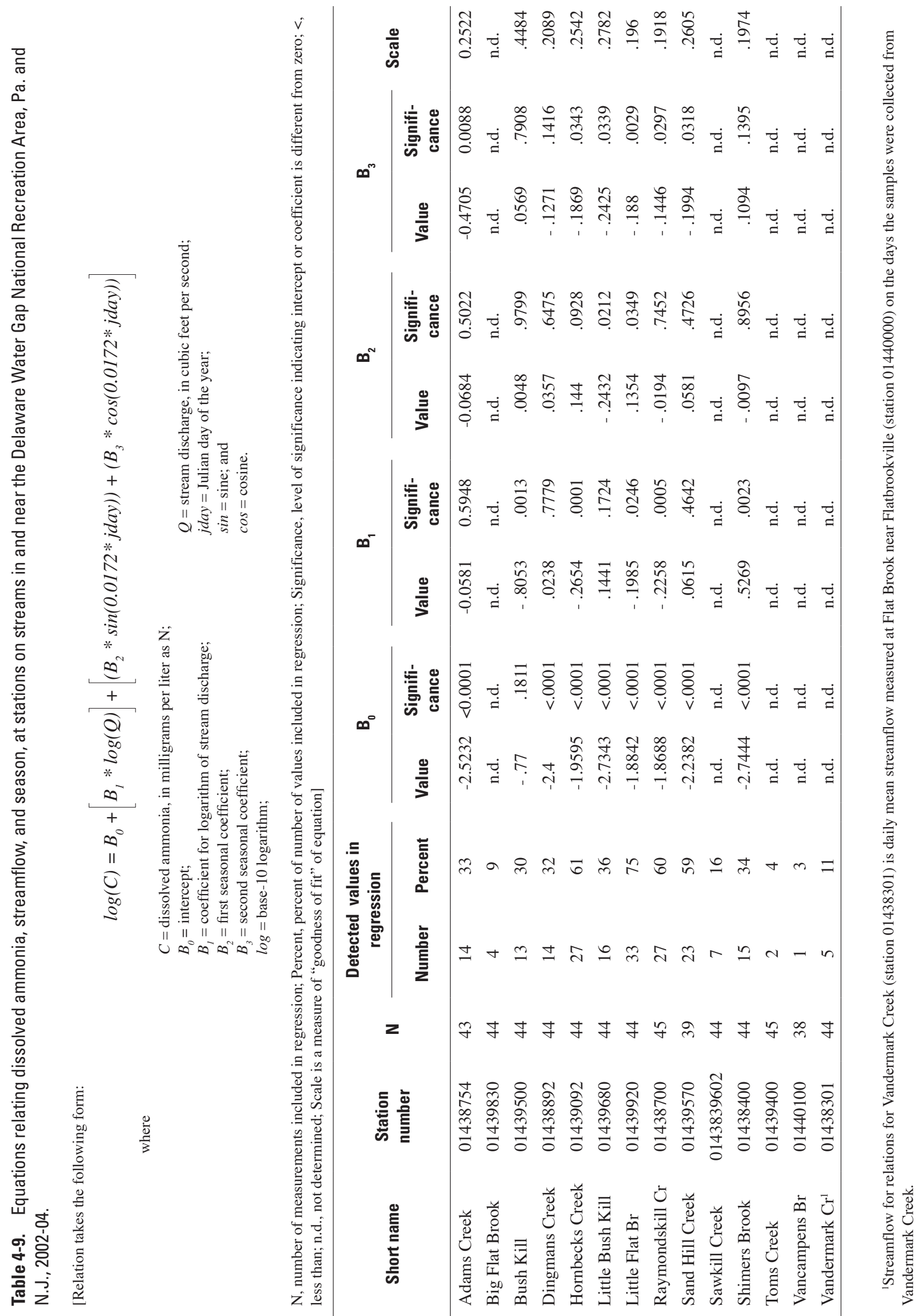

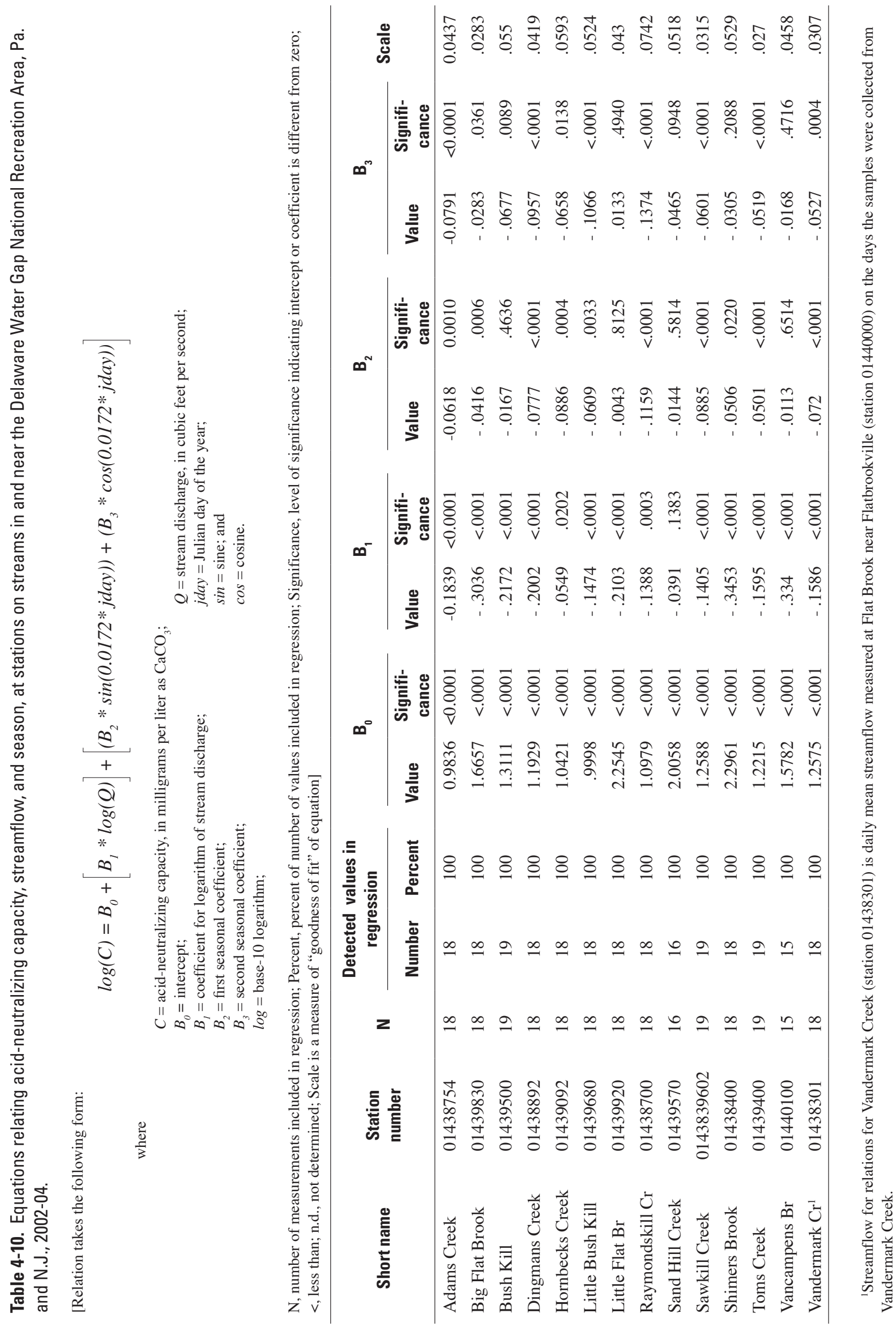

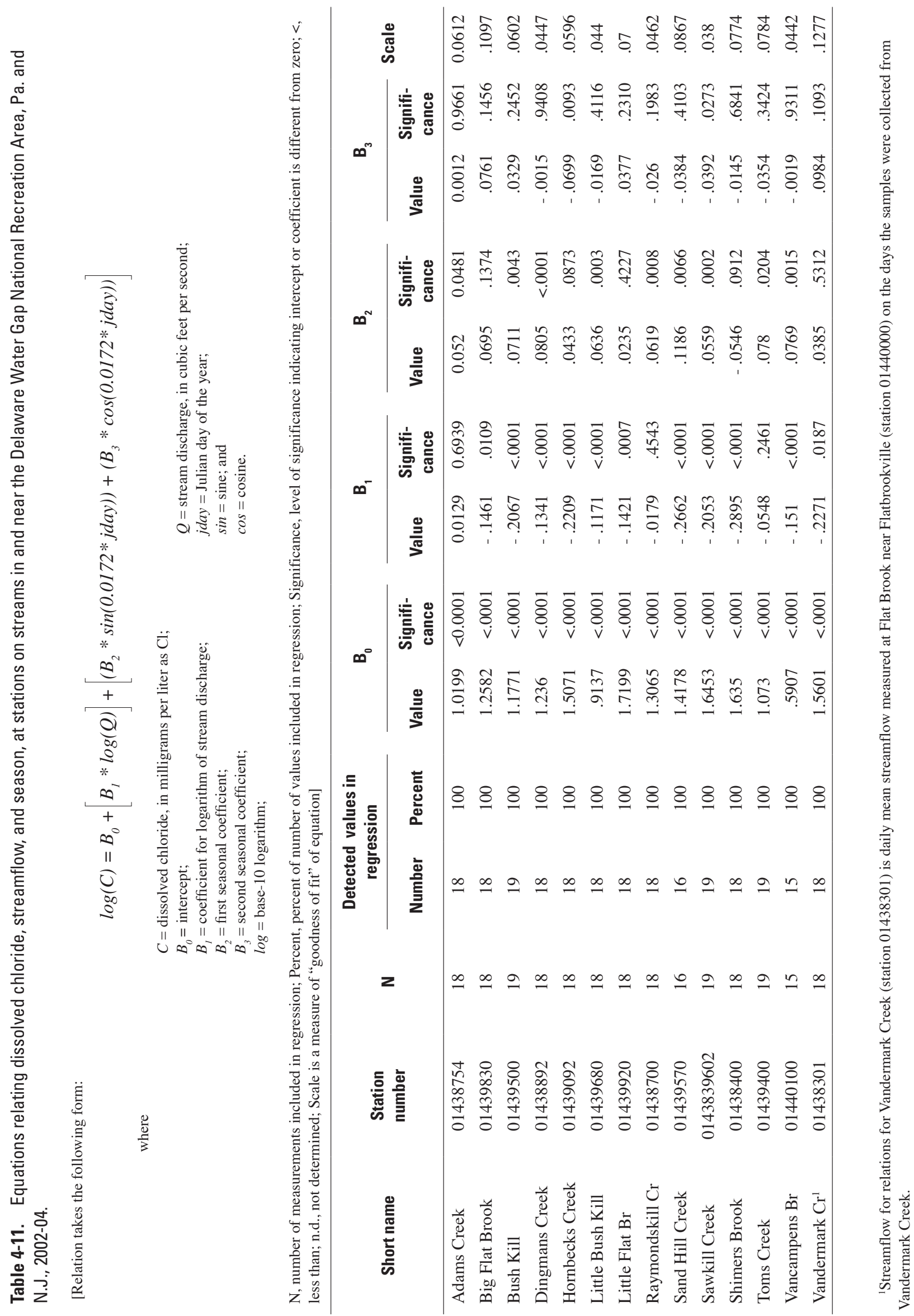

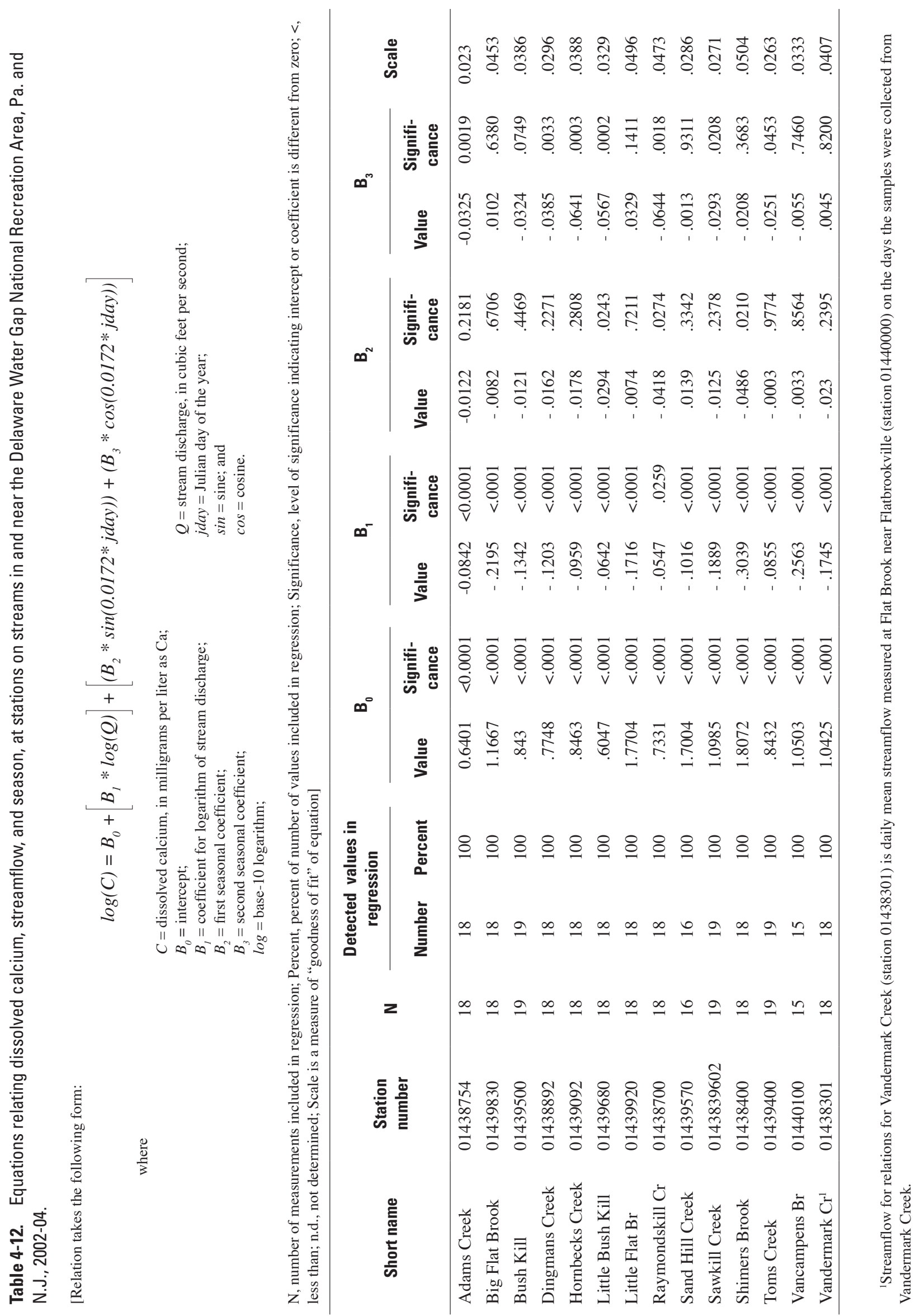

For additional information, write to:

Director

U.S. Geological Survey

New Jersey Water Science Center

Mountain View Office Park

810 Bear Tavern Rd., Suite 206

West Trenton, NJ 08628

or visit our Web site at:

http://nj.usgs.gov/ 
